\title{
A synthesis of atmospheric mercury depletion event chemistry in the atmosphere and snow
}

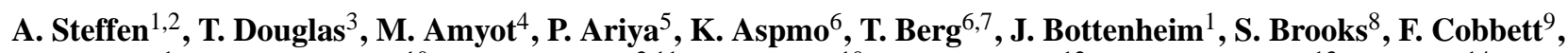 \\ A. Dastoor ${ }^{1}$, A. Dommergue ${ }^{10}$, R. Ebinghaus ${ }^{2,11}$, C. Ferrari ${ }^{10}$, K. Gardfeldt ${ }^{12}$, M. E. Goodsite ${ }^{13}$, D. Lean ${ }^{14}$, \\ A. J. Poulain ${ }^{4}$, C. Scherz ${ }^{15}$, H. Skov ${ }^{16}$, J. Sommar ${ }^{12}$, and C. Temme ${ }^{11}$ \\ ${ }^{1}$ Environment Canada, Air Quality Research Division, 4905 Dufferin Street, Toronto, Ontario, M3H 5T4, Canada \\ ${ }^{2}$ Universität Lüneburg, Scharnhorststraße 1/13, 21335, Luneburg, Germany \\ ${ }^{3}$ US Army Cold Regions Research and Engineering Laboratory Fort Wainwright, Alaska, USA \\ ${ }^{4}$ Département de Sciences Biologiques, Université de Montréal, Pavillon Marie-Victorin, Montréal (QC) H3C 3J7, Canada \\ ${ }^{5}$ Departments of Chemistry and Atmospheric and Oceanic Sciences, McGill University, 801 Sherbrooke St. W., Montreal, \\ PQ, H3A 2K6, Canada \\ ${ }^{6}$ Norwegian Institute for Air Research, Instituttveien 18, 2027 Kjeller, Norway \\ ${ }^{7}$ Norwegian University of Science and Technology, Department of Chemistry, 7491 Trondheim, Norway \\ ${ }^{8}$ National Oceanic and Atmospheric Administration, Atmospheric Turbulence and Diffusion Division, Oak Ridge, TN, USA \\ ${ }^{9}$ School of Engineering, University of Guelph, Guelph, ON, N1G 2W1, Canada \\ ${ }^{10}$ Laboratoire de Glaciologie et Géophysique de l'Environnement (LGGE) and Universite Joseph Fourier, France \\ ${ }^{11}$ GKSS-Forschungszentrum Geesthacht GmbH, Institute for Coastal Research, Department for Environmental Chemistry, \\ Max-Planck-Str. 1, 21052 Geesthacht, Germany \\ ${ }^{12}$ Göteborg University and Chalmers University of Technology, 41296 Göteborg, Sweden \\ ${ }^{13}$ University of Southern Denmark, Department of Physics and Chemistry Campusvej 55, 5230 Odense M, Denmark \\ ${ }^{14}$ University of Ottawa, Department of Biology, Centre for Advanced Research in Environmental Genomics, P.O. Box 450 \\ Station A. 20 Marie Curie, Ottawa, ON K1N 6N5, Canada \\ ${ }^{15} 4$ Hollywood Crescent, Toronto, M4L 2K5, Canada \\ ${ }^{16}$ National Environmental Research Institute, Frederiksborgvej 399, 4000 Roskilde, Denmark
}

Received: 1 June 2007 - Published in Atmos. Chem. Phys. Discuss.: 26 July 2007

Revised: 4 January 2008 - Accepted: 12 February 2008 - Published: 12 March 2008

\begin{abstract}
It was discovered in 1995 that, during the spring time, unexpectedly low concentrations of gaseous elemental mercury (GEM) occurred in the Arctic air. This was surprising for a pollutant known to have a long residence time in the atmosphere; however conditions appeared to exist in the Arctic that promoted this depletion of mercury $(\mathrm{Hg})$. This phenomenon is termed atmospheric mercury depletion events (AMDEs) and its discovery has revolutionized our understanding of the cycling of $\mathrm{Hg}$ in Polar Regions while stimulating a significant amount of research to understand its impact to this fragile ecosystem. Shortly after the discovery was made in Canada, AMDEs were confirmed to occur throughout the Arctic, sub-Artic and Antarctic coasts. It is now known that, through a series of photochemically initiated reactions involving halogens, GEM is converted to a
\end{abstract}

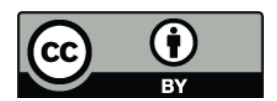

Correspondence to: A. Steffen (alexandra.steffen@ec.gc.ca) more reactive species and is subsequently associated to particles in the air and/or deposited to the polar environment. AMDEs are a means by which $\mathrm{Hg}$ is transferred from the atmosphere to the environment that was previously unknown. In this article we review $\mathrm{Hg}$ research taken place in Polar Regions pertaining to AMDEs, the methods used to collect $\mathrm{Hg}$ in different environmental media, research results of the current understanding of AMDEs from field, laboratory and modeling work, how $\mathrm{Hg}$ cycles around the environment after AMDEs, gaps in our current knowledge and the future impacts that AMDEs may have on polar environments. The research presented has shown that while considerable improvements in methodology to measure $\mathrm{Hg}$ have been made but the main limitation remains knowing the speciation of $\mathrm{Hg}$ in the various media. The processes that drive AMDEs and how they occur are discussed. As well, the role that the snow pack and the sea ice play in the cycling of $\mathrm{Hg}$ is presented. It has been found that deposition of $\mathrm{Hg}$ from AMDEs occurs at marine coasts and not far inland and that a fraction of the

Published by Copernicus Publications on behalf of the European Geosciences Union. 


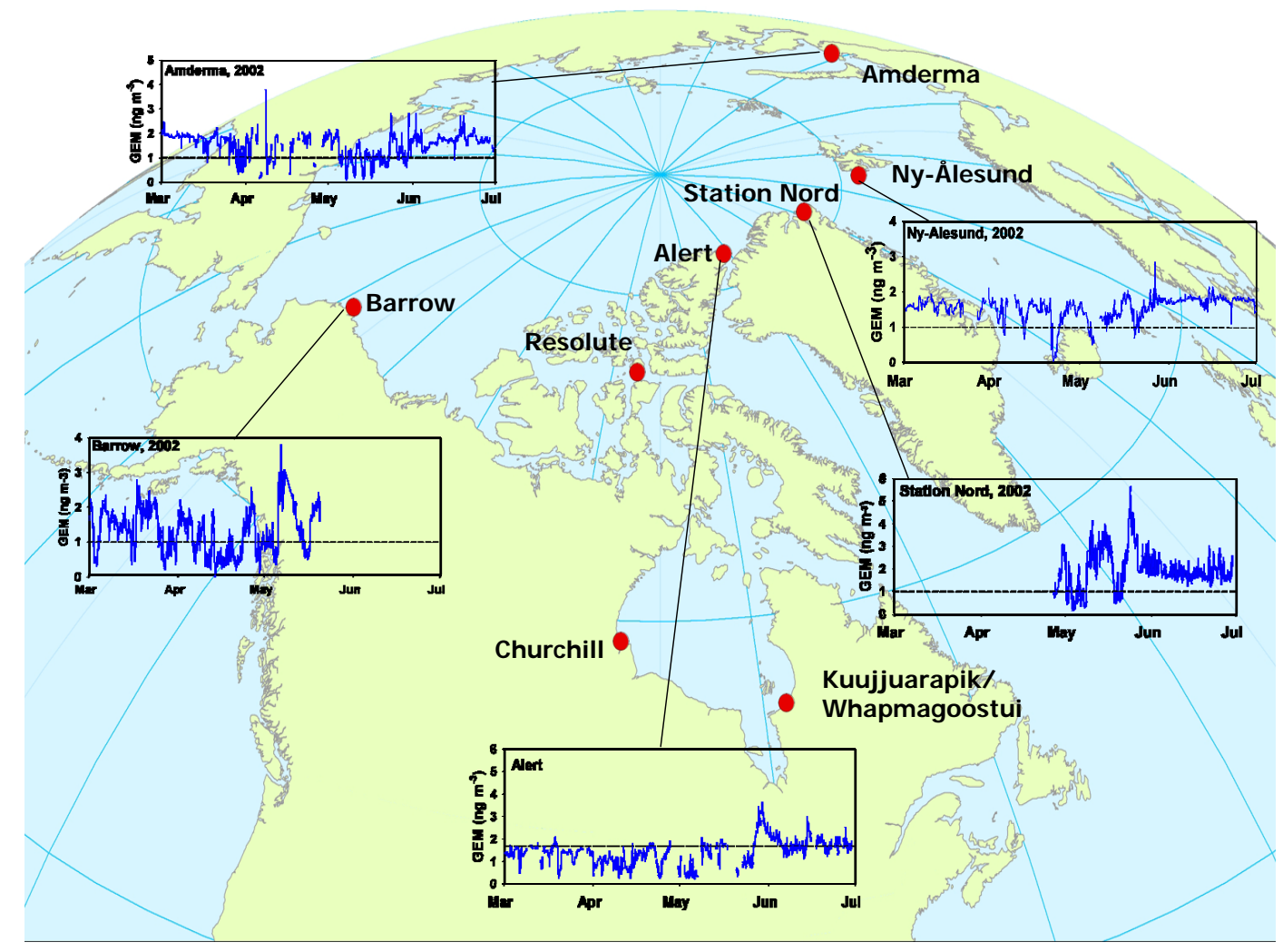

Fig. 1. Map of sampling sites for mercury research undertaken in the Arctic (and sub-Arctic) including time series of GEM concentrations at Amderma, Barrow, Ny-Ålesund, Station Nord and Alert during spring 2002. These time series demonstrate that during the Arctic spring, all sites show occurrence of AMDEs by concentrations going below $1 \mathrm{ng} / \mathrm{m}^{3}$ (as indicated by the dashed line).

deposited $\mathrm{Hg}$ does not remain in the same form in the snow. Kinetic studies undertaken have demonstrated that bromine is the major oxidant depleting $\mathrm{Hg}$ in the atmosphere. Modeling results demonstrate that there is a significant deposition of $\mathrm{Hg}$ to Polar Regions as a result of AMDEs. Models have also shown that $\mathrm{Hg}$ is readily transported to the Arctic from source regions, at times during springtime when this environment is actively transforming $\mathrm{Hg}$ from the atmosphere to the snow and ice surfaces. The presence of significant amounts of methyl $\mathrm{Hg}$ in snow in the Arctic surrounding AMDEs is important because this species is the link between the environment and impacts to wildlife and humans. Further, much work on methylation and demethylation processes has occurred but these processes are not yet fully understood. Recent changes in the climate and sea ice cover in Polar Regions are likely to have strong effects on the cycling of $\mathrm{Hg}$ in this environment; however more research is needed to understand $\mathrm{Hg}$ processes in order to formulate meaningful predictions of these changes.

\section{Introduction}

The first continuous measurements of surface level atmospheric mercury $(\mathrm{Hg})$ concentrations began at Alert, Canada in 1995 (Fig. 1). To the astonishment of the investigators, they observed rapid episodically very low concentrations of gaseous elemental Hg (GEM) between March and June. To appreciate the significance of these results it should be understood that until that time there was general agreement that the atmospheric residence time of GEM was 6-24 months (Schroeder and Munthe, 1995) and little variation in the atmospheric concentration of $\mathrm{Hg}$ was reported from any other location. Even though the episodes of low GEM concentrations strongly correlated with similar periods of low ground level ozone that were reported at the same location (Barrie et al., 1988), it took several years of consecutive measurements before the investigators felt convinced that this was a real phenomenon and reported their observations (Schroeder et al., 1998). It is now well established that these low GEM concentrations, termed atmospheric mercury depletion events (AMDEs), are an annual recurring spring time phenomenon (Steffen et al., 2005). Furthermore, the occurrence of AMDEs has now been observed throughout Polar Regions (see Fig. 1) at Ny-Ålesund, Svalbard $78^{\circ} 54^{\prime}$ N $11^{\circ} 53^{\prime} \mathrm{E}$ 
(Berg et al., 2003a); Pt. Barrow, Alaska $71^{\circ} 19^{\prime} \mathrm{N} 156^{\circ} 37^{\prime} \mathrm{W}$ (Lindberg et al., 2001); Station Nord, Greenland $81^{\circ} 36^{\prime} \mathrm{N}$ $16^{\circ} 40 \mathrm{E}$ (Skov et al., 2004); Kuujjuarapik, Quebec $55^{\circ} 16^{\prime} \mathrm{N}$ $77^{\circ} 45^{\prime} \mathrm{W}$ (Poissant and Pilote, 2003); Amderma, Russia $69^{\circ} 45^{\prime} \mathrm{N} 61^{\circ} 40^{\prime} \mathrm{E}$ (Steffen et al., 2005) and Neumeyer, Antartica $70^{\circ} 39^{\prime} \mathrm{S} 8^{\circ} 15^{\prime} \mathrm{W}$ (Ebinghaus et al., 2002), resulting in over 200 publications on the topic in the 5 years after the first report.

The depletion events demonstrate the existence of mechanisms representing the very fast removal of $\mathrm{Hg}$ from the atmosphere. However, surface based observations do not show a total removal of $\mathrm{Hg}$ from the atmosphere in the vertical column. In fact, the depletions appear to be limited vertically from the terrestrial or ocean surface up to a surface boundary layer of usually less than $1 \mathrm{~km}$ depth (Banic et al., 2003; Tackett et al., 2007). Even though these AMDEs are confined to the boundary layer, it is estimated that they can lead to the deposition of up to 300 tonnes of $\mathrm{Hg}$ per year to the Arctic (Ariya et al., 2004; Skov et al., 2004). It is known that a unique series of photochemically initiated reactions involving ozone and halogen compounds, largely of marine origin, and especially bromine oxides $\left(\mathrm{BrO}_{\mathrm{x}}, \mathrm{Br}, \mathrm{BrO}\right)$, lead to the destruction of ozone (Simpson et al., 2007). Given the close correlation between ozone depletion events (ODEs) and AMDEs (see Fig. 2), it has been hypothesized that $\mathrm{BrO}_{\mathrm{x}}$, in turn, oxidizes GEM to reactive gaseous mercury (RGM) that is readily scavenged by snow and ice surfaces (Schroeder et al., 1998). AMDEs are only reported during polar springtime suggesting that sea ice or, more specifically, refreezing ice in open leads provides a halogen source that drives AMDE chemistry (Lindberg et al., 2002; Kaleschke, 2004; Simpson et al., 2007; Brooks et al., 2006).

In 1996, a review was published that clearly identified mercury as a heavy metal of great concern because of its anthropogenic mobilization during the last century and its ability to bioaccumulate and biomagnify Arctic marine wildlife (Macdonald and Bewers, 1996). This paper further recommended that work was urgently needed to verify trends of mercury in various media including the atmosphere, the oceans, the water system and the biota. While the discovery of AMDEs in 1995 initiated almost a decade of intense study of atmospheric $\mathrm{Hg}$ processes, there have been many studies of $\mathrm{Hg}$ Polar Regions prior to this discovery. This work was driven by the fact that $\mathrm{Hg}$ has strongly toxic properties, readily bioaccumulates in food webs, is found in elevated levels in arctic marine mammals and, in some locations, is above acceptable levels in the cord blood of mothers (Wagemann et al., 1998; Arnold et al., 2003; Lockhart et al., 2005a; Lockhart et al., 2005b). For example, elemental $\mathrm{Hg}$ entering the environment can be converted to bioavailable oxidized $\mathrm{Hg}$ which can then be converted to a methylated $\mathrm{Hg}$ species through a variety of abiotic and biotic processes. For biota, exposure to $\mathrm{MeHg}$ causes central nervous system effects, including a loss of coordination, inability to feed, a reduced responsiveness to stimuli and starvation. $\mathrm{MeHg}$ is a contam-

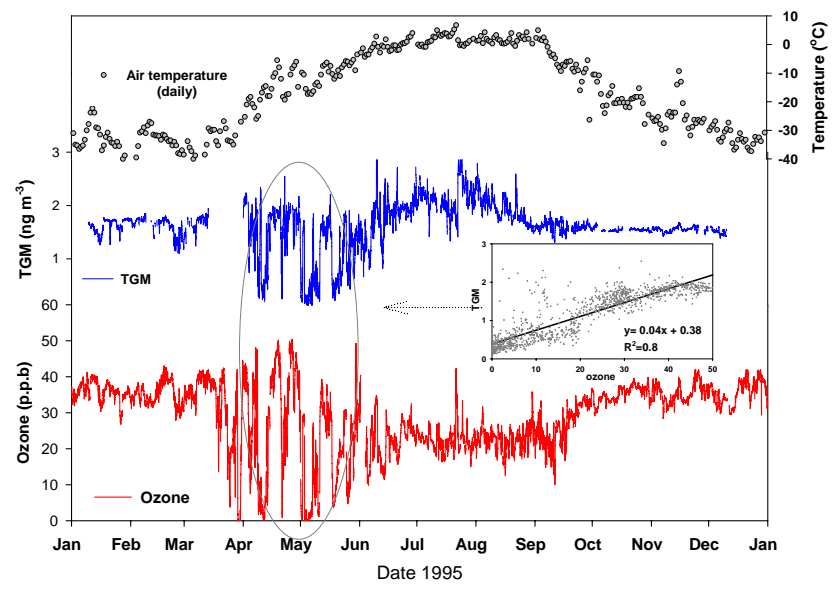

Fig. 2. Annual time series of TGM and ozone concentrations and air temperature from Alert 1995. Insert: linear correlation between TGM and ozone during an AMDE time period (adapted from Schroeder et al., 1998).

inant of grave concern because it can cross the blood brain barrier and can also act as an immunosuppressant rendering animals and humans more susceptible to disease (Eisler, 1987; Thompson, 1996; Derome et al., 2005). Subtle health effects are occurring in certain areas of the Arctic due to exposure to $\mathrm{Hg}$ in traditional food, and the dietary intake of $\mathrm{Hg}$ has, at times, exceeded established national guidelines in a number of communities (Johansen et al., 2000; Johansen et al., 2004). Evidence suggests that the greatest concern is for fetal and neonatal development. For example, evidence of neurobehavioral effects in children have been reported in the Faroe Islands (Grandjean et al., 1997) and in Inuit children in northern Quebec (Saint-Amour et al., 2006) who have been exposed to $\mathrm{Hg}$ through the consumption of country food. It has also been shown that the effects of $\mathrm{Hg}$ in the Arctic can have adverse economic effects in this region (Hylander and Goodsite, 2006).

Mercury has unique characteristics that include long-range atmospheric transport, the transformation to more toxic methylmercuric compounds and the ability of these compounds to biomagnify in the aquatic food chain. This has motivated intensive research on $\mathrm{Hg}$ as a pollutant of global concern. As well, interest in $\mathrm{Hg}$ in Polar Regions was accelerated with the discovery of AMDEs and this led to interest in snow measurements that yielded the highest reported concentrations of $\mathrm{Hg}$ in snow in a remote pristine ecosystem (Schroeder et al., 1998; Douglas et al., 2005). In 2006 alone, more than 40 publications have appeared relating to $\mathrm{Hg}$ in the Arctic. $\mathrm{Hg}$ is on the priority list of a large (and increasing) number of international agreements, conventions and national advisories aimed at environmental protection including all compartments, human health and wildlife (e.g. The Arctic Monitoring and Assessment Programme (AMAP), United Nations - Economic Commission 
for Europe: Heavy Metals Protocol (UN-ECE), The Helsinki Commission (HELCOM), The OSPAR convention and many others).

The objective of this review article is to provide a comprehensive synthesis of the available science behind AMDEs and the research that has been undertaken in the arena of $\mathrm{Hg}$ in Polar Regions in the ten years since the discovery of AMDEs. This review article will first examine features of the environmental importance of $\mathrm{Hg}$ with a focus on issues of special importance for Polar Regions. This will be followed by sections outlining the measurement techniques used in field and laboratory experiments and a summary of results from field and laboratory based investigations of atmospheric processes. In addition, reviews of the modeling efforts that have been undertaken to better predict deposition and storage scenarios will be presented. The review will conclude by identifying gaps in our current understanding of mercury in polar environments and offering an outlook of potential future directions of $\mathrm{Hg}$ research in Polar Regions.

\section{Mercury in the environment}

Mercury behaves exceptionally in the environment due to its volatility, its potential to be methylated and its ability to bioaccumulate in aquatic food webs. Mercury is emitted into the atmosphere from a number of natural and anthropogenic sources. Experimental field data and model estimates indicate that anthropogenic $\mathrm{Hg}$ emissions are at least as great as those from natural sources (Mason et al., 1994; Fitzgerald et al., 1998; Martinez-Cortizas et al., 1999; Mason and Sheu, 2002; Pacyna et al., 2006). The change of the global atmospheric pool of $\mathrm{Hg}$ over time and the resulting concentration levels of gaseous elemental $\mathrm{Hg}$ are poorly defined. It is believed that anthropogenic emissions are leading to a general increase in $\mathrm{Hg}$ on local, regional and global scales and that the increase in global deposition to terrestrial and aquatic ecosystems since pre-industrial times is about a factor of $3 \pm 1$ (Lindberg et al., 2007). While the observed increase in $\mathrm{Hg}$ concentrations following the planet's industrialization has been documented, it is more difficult to understand the natural $\mathrm{Hg}$ cycle without the influence of anthropogenic activities. Ice cores provide a record for examining $\mathrm{Hg}$ deposition during changing climatic cycles (ice cores can reach up to 900000 years in Antarctica, 150000 years in Greenland). For example, Vandal et al. (1993) showed that for samples from the past 34000 years, $\mathrm{Hg}$ concentrations were higher during the last glacial maximum, when oceanic productivity may have been higher than it is today. They therefore suggest that the oceans were the principal pre-industrial source of $\mathrm{Hg}$ to the atmosphere.

$\mathrm{Hg}$ participates in a number of complex environmental processes and interest has largely focused on the aquatic, biological and atmospheric cycles. Environmental cycling of $\mathrm{Hg}$ can be described as a series of chemical, biological and physical transformations that govern the distribution of $\mathrm{Hg}$ in and between different compartments of the environment. $\mathrm{Hg}$ can exist in a number of different chemical species, each with their own range of physical, chemical and ecotoxicological properties. These properties are of fundamental importance for the environmental behaviour of $\mathrm{Hg}$ (UNEP, 2002).

The three most important species of Hg known to occur in the environment are as follows (Schroeder and Munthe, 1998):

- Elemental mercury $(\mathrm{Hg})\left[\mathrm{Hg}^{0}\right.$ or $\left.\mathrm{Hg}(0)\right]$ which has a high vapour pressure and a relatively low solubility in water. Of the $\mathrm{Hg}$ species found in the atmosphere, $\mathrm{Hg}(0)$ is the most stable and dominant and is subject to undergo long range transport;

- Divalent inorganic mercury $\left[\mathrm{Hg}^{2+}\right.$ or $\left.\mathrm{Hg}(\mathrm{II})\right]$ which is thought to be the principle form in wet deposition, is more soluble in water than $\mathrm{Hg}(0)$ and has a strong affinity for many inorganic and organic ligands, especially those containing sulphur;

- Methyl mercury $\left[\mathrm{CH}_{3} \mathrm{Hg}^{+}\right.$or $\left.\mathrm{MeHg}\right]$ which is toxic and is strongly bio-accumulated by living organisms.

\subsection{Mercury pollution in the Polar Regions}

Polar ecosystems are generally considered to be the last pristine environments on earth. The Arctic, for example, is not densely populated and has, relative to temperate regions, little industrial activity (except select areas in the Russian Arctic (Bard, 1999) and mining in Svalbard) and is therefore perceived to be relatively unaffected by human activity. Antarctica is considered to be even less affected than the Arctic by anthropogenic influences because of its isolated location far from industrial activities which are predominantly located in the northern hemisphere. However, long distance atmospheric transport brings anthropogenic contaminants from mid- and low latitude sources to both Polar Regions (Bard, 1999).

Polar Regions contain fragile ecosystems and unique conditions that make the impact of external pollutants a larger threat than in other regions (Macdonald et al., 2005). In the Arctic, $\mathrm{Hg}$ levels are shown to be higher in the upper layers of marine sediment indicating that $\mathrm{Hg}$ input to the Arctic is post-industrially driven (Hermanson, 1998). Evidence from ice core samples confirms this. While this is not unique to the Arctic, it is often taken as evidence that industrialization is present in this region although some have suggested that this may not always be the case (Gobeil et al., 1999). Ice core studies from Greenland (Boutron et al., 1998; Mann et al., 2005) observed higher $\mathrm{Hg}$ concentrations in snow between the late 1940s to the mid 1960s, when industrial activities that produced considerable $\mathrm{Hg}$ were high, than in more recent snow. This trend has also been observed in other environmental media such as peat from Southern Greenland (Shotyk et al., 2003). 
Reports have found that some marine mammals in the Canadian Arctic exceed human consumption guidelines and that $\mathrm{Hg}$ has been recorded above acceptable levels in the cord blood of mothers (Wagemann et al., 1998; Arnold et al., 2003; Lockhart et al., 2005a). Perhaps most striking is that $\mathrm{Hg}$ levels recorded in some northerners living in the Arctic are higher than those recorded in people from more temperate, industrialized regions where most of the $\mathrm{Hg}$ originates (Arnold et al., 2003). Mercury readily bioaccumulates in freshwater ecosystems and in marine wildlife but the pathways by which $\mathrm{Hg}$ is introduced to these environments are not well understood. The unpredictability in the spatial and temporal trends of $\mathrm{Hg}$ levels in marine wildlife throughout the Arctic indicates that the high $\mathrm{Hg}$ concentrations found in some species are likely driven by local or regional influences (Riget et al., 2007). The traditional way of life for northerners relies heavily on the consumption of country food (the wildlife) and this is of concern because much of these foods contain elevated $\mathrm{Hg}$ levels.

There are four major pollutant groups (listed below) that are well known to migrate to high latitudes. Three have been well known for more than a decade while the fourth group, a new and emerging group of organic contaminants, is of growing concern:

1. acidifying gases $\left(\mathrm{SO}_{\mathrm{x}}\right)$ from Eurasian smelters and industry (Barrie et al., 1989)

2. heavy metals, including $\mathrm{Hg}$, from fossil fuel combustion, industry and mining (Akeredolu et al., 1994)

3. classical persistent organic pollutants (POPs) including pesticides and polychlorinated biphenyls (Muir et al., 1992), and

4. emerging POPs, such as brominated flame retardants (BFRs) and polyfluorinated compounds (PFOA, PFOS) (Giesy and Kannan, 2001; Smithwick et al., 2005).

These contaminants are of concern because most of them biomagnify through the marine food chain to elevated levels in top predators, including humans, which may create adverse physiological effects (Dewailly et al., 1991; Bacon et al., 1992; Bossi et al., 2005). POPs and the other semivolatile pollutants mentioned above are known to be transported to the Arctic via the "grasshopper effect" (Wania and Mackay, 1996). Both POPs and Hg are subject to partitioning onto particles and deposition from the atmosphere, however, unlike POPs much of the deposition of $\mathrm{Hg}$ in the Arctic results from photochemical reactions. Since $\mathrm{Hg}$ can exist in the atmosphere in various forms for long periods of time, there are several pathways by which $\mathrm{Hg}$ can arrive in remote locations.

Rapid changes in global atmospheric circulation systems also play key roles in how the pristine environment of the Arctic becomes contaminated (Barrie, 1986; Heidam et al., 2004). The Arctic troposphere is characterized by stable stratification and minimal vertical mixing in the winter and spring periods (Raatz, 1992). During the Arctic summer, the troposphere is well mixed which prevents the accumulation of atmospheric pollutants. In the winter and spring, pollutants accumulate in the Arctic because of a combination of robust stratification, resulting from strong surface temperature inversions inhibiting turbulent transport, and the atmospheric transport of pollutants from mid-latitudes. This pole ward transport of pollutants is due to the geographic position of a meteorological phenomenon known as blocking (Iversen and Joranger, 1985). Mid-latitude pollutant source regions undergo periods of atmospheric stagnation resulting in weather conditions that reduce contaminant scavenging rates and thus permit accumulation of pollutants over these source areas (Dastoor and Pudykiewicz, 1996). If a cyclonic system approaches a blocking high in these mid-latitudes, a strong pressure gradient builds and forces polluted air masses northward. If the transport path persists long enough, these polluted air masses can reach the Arctic troposphere within 2 to 10 days (Raatz and Shaw, 1984; Oehme, 1991; Weller and Schrems, 1996). Once atmospheric contaminants reach the Polar Regions, their lifetime in the troposphere is then controlled by local removal processes. The fate of transported $\mathrm{Hg}$ to the Arctic is discussed further in Sect. 6.

\subsection{Mercury in the atmosphere}

The long residence time of GEM in the atmosphere is about one year (Schroeder and Munthe, 1995) and is thus sufficient to allow for homogeneous mixing, at least within the hemisphere of origin. Since anthropogenic sources of $\mathrm{Hg}$ emissions into the atmosphere are primarily located in the northern hemisphere, a concentration gradient between the two hemispheres should be expected. Indeed, the global background concentration (the average sea-level atmospheric concentration of $\operatorname{Hg}(0)$ at remote sites) is generally 1.5$1.7 \mathrm{ng} / \mathrm{m}^{3}$ in the northern hemisphere and $1.1-1.3 \mathrm{ng} / \mathrm{m}^{3}$ in the southern hemisphere (Ebinghaus et al., 2002; Slemr et al., 2003; Temme et al., 2004; Kock et al., 2005). The lifetime of $\mathrm{Hg}$ in the atmosphere also depends on its chemical form. Gaseous elemental mercury can be transported globally while oxidized forms of $\mathrm{Hg}$ are more reactive and travel much shorter distances before they are scavenged or deposited. Temporal variations in deposition can result from changes in $\mathrm{Hg}$ emission rates, changes in local and regional sources (e.g. $\mathrm{NO}_{\mathrm{x}}$ and $\mathrm{SO}_{2}$ ) and, potentially, from changes in climate (e.g. changes in precipitation amounts, air temperature, sea ice coverage) (Macdonald et al., 2005). An increase of $\mathrm{O}_{3}$ concentrations and aerosol loadings will also impact the atmospheric residence time and deposition fluxes of elemental and oxidized mercury (Lindberg et al., 2007). It is likely that global mercury cycling has changed over time not only by anthropogenic emissions but by increases in the oxidation potential of the atmosphere itself since the industrial revolution (Lindberg et al., 2007). 
Table 1. Continental Hg emission trends from 1990 to 2000 and related uncertainties based on (Pacyna et al., 2006) and adopted from (Lindberg et al., 2007).

\begin{tabular}{llll}
\hline Continent & 1990-1995 (tones/yr) & 1995-2000 (tones/yr) & Uncertainty \\
\hline Africa & 2-fold increase: 200 to 400 & constant level: 400 & $\pm 50 \%$ \\
Asia & 2-fold increase: 600 to 1200 & constant level: 1200 & $\pm 40 \%$ \\
Australia & 2-fold increase: 50 to 100 & constant level: 100 & $\pm 30 \%$ \\
Europe & decline: 550 to 300 & further reduction to 200 & $\pm 30 \%$ \\
North America & slight decline: 220 & fairly constant: 200 & $\pm 27 \%$ \\
South America & 30\% increase: 55 to 80 & fairly constant: 80 & $\pm 50 \%$ \\
\hline
\end{tabular}

The most prevalent species of $\mathrm{Hg}$ in the atmosphere include gaseous elemental mercury (GEM) or $\mathrm{Hg}(0)$; oxidized reactive gaseous mercury (RGM), consisting of $\mathrm{Hg}$ (II) or $\mathrm{Hg}(\mathrm{I})$ compounds, and particle-bound $\mathrm{Hg}$ (II or I) mercury (PHg). Due to the methods used to measure these atmospheric species (see Sect. 3) and the lack of current analytical standards other than for GEM, information on the speciation/fractionation of these different chemical and physical forms is limited. As a consequence, RGM and PHg are considered operationally defined for this publication.

The reactive forms of $\mathrm{Hg}$ (e.g. RGM and some $\mathrm{PHg}$ ) have short lifetimes in the atmosphere and are deposited from the atmosphere close to emission sources. However, the existence of reactive $\mathrm{Hg}$ in a particular air sample does not necessarily imply the existence of a local emission source but can be the result of atmospheric chemical reactions involving GEM transported from distant sources (Gauchard et al., 2005; Bottenheim and Chan, 2006; Lindberg et al., 2007). Experimental evidence demonstrating the presence and production of RGM and $\mathrm{PHg}$ at remote locations ranging from Polar Regions to the open ocean will be discussed in more detail in Sect. 4 (Schroeder et al., 1998; Lindberg et al., 2002; Berg et al., 2003a; Temme et al., 2003; Laurier et al., 2003; Skov et al., 2004).

\subsection{Worldwide anthropogenic mercury sources}

The onset of the major industrial activities since the 1940's has altered the global $\mathrm{Hg}$ cycle via the anthropogenic transfer of large quantities of $\mathrm{Hg}$ from deep geological stores to the Earth's surface and atmosphere (Ebinghaus et al., 1999; Ferrara, 1999; Shotyk et al., 2003). Several historic sediment and peat bog records from remote sites in both the northern and the southern hemispheres indicate a 2-4 fold increase in $\mathrm{Hg}$ deposition since pre-industrial times (Engstrom and Swain, 1997; Bindler et al., 2001; Lamborg et al., 2002; Shotyk et al., 2003; Givelet et al., 2004; Fitzgerald et al., 2005; Shotyk et al., 2005). North American and European $\mathrm{Hg}$ emissions are decreasing while those in Asia and Africa are increasing but the latter changes are less well documented and thus carry a larger uncertainty (see Table 1 ). Slemr et al. (2003) attempted to reconstruct the worldwide trend of at- mospheric $\mathrm{Hg}$ concentrations from long-term measurements at 6 sites in the northern hemisphere, 2 sites in the southern hemisphere and multiple intermittent ship cruises over the Atlantic Ocean since 1977. They suggest that Hg concentrations in the global atmosphere have increased since the first measurements in 1977 to a maximum in the 1980s, subsequently decreased to a minimum in 1996 and then remained at a constant level of about $1.7 \mathrm{ng} / \mathrm{m}^{3}$, in the northern hemisphere, until 2001. However, this assessment and analysis includes several significant assumptions and an alternative hypothesis has been proposed that suggests that the total gaseous $\mathrm{Hg}$ concentration in the northern hemisphere remained virtually unchanged since 1977 (Lindberg et al., 2007). As mentioned in the previous section, factors including the change in the oxidation potential of the atmosphere over the past several decades (Schimel, 2000) may partially account for the discrepancy between measurement trends of atmospheric $\mathrm{Hg}$ (either constant or decreasing) and $\mathrm{Hg}$ emission inventories (increasing: Lindberg et al., 2007). Further, Lindberg et al. (2007) conclude that reductions in anthropogenic inputs will not produce a linear decrease in $\mathrm{Hg}$ deposition, especially at remote locations that are dominated by the global pool. A further understanding of atmospheric $\mathrm{Hg}$ chemical kinetics and deposition (re-emission) processes (in Polar Regions and elsewhere) is warranted to truly understand the impacts of global emission reductions of $\mathrm{Hg}$ on atmospheric $\mathrm{Hg}$ concentrations.

\subsection{Mercury in snow and air and snow and ice interactions}

Mercury can be deposited onto snow surfaces through both wet and dry deposition. Dry deposition in Polar Regions mainly corresponds with the deposition of RGM formed during AMDEs (Lu et al., 2001; Lindberg et al., 2002; Ariya et al., 2004). Mercury in snow is mainly found in its oxidised form (e.g. $\mathrm{Hg}(\mathrm{II}))$ with concentrations that can range from a few up to hundreds of ng/L (Lalonde et al., 2002; Lindberg et al., 2002; Steffen et al., 2002; Berg et al., 2003a; Ferrari et al., 2004a; Ferrari et al., 2005; Lahoutifard et al., 2006). AMDEs can lead to increased $\mathrm{Hg}$ concentrations in the surface snow (Lu et al., 2001; Lindberg et al., 2002; Brooks et al., 2006), however, it has also been observed that within 
$24 \mathrm{~h}$ after deposition of $\mathrm{Hg}$ from the atmosphere, a fraction is re-emitted as GEM back to the atmosphere (Lalonde et al., 2002; Dommergue et al., 2003a). Polar snow packs themselves have been investigated for their role as a chemical reactor that leads to the formation of active oxidants/reductants (Dominé and Shepson, 2002). Hence it appears that snow packs can act both as a sink and a source of $\mathrm{Hg}$ to the atmosphere depending on the environmental conditions (e.g. temperature, irradiation, presence of water layers around snow grains) and the chemical composition of the snow (e.g. presence of halogens, organic substances) (Lalonde et al., 2002; Dommergue et al., 2003b; Dommergue et al., 2003a; Lalonde et al., 2003; Fain et al., 2006a).

The concentration of MeHg within the snow pack has been reported at 3 orders of magnitude lower than total $\mathrm{Hg}$ in polar snow samples within the range of 10-200 pg/L (Ferrari et al., 2004b; Lahoutifard et al., 2005; St. Louis et al., 2005). The fraction of mercury that is detected by a luminescent bioreporter, also known as the "bioavailable" fraction of $\mathrm{Hg}$, in Arctic snow at Barrow was reported to be approximately $45 \%$ of the total $\mathrm{Hg}$ just prior to annual melt (Scott, 2001). The author proposed that the fraction of bioavailable $\mathrm{Hg}$ had increased in the surface snow between polar sunrise and spring melt due to deposition ascribed to AMDEs (Scott, 2001).

There is much discussion about the fate of the deposited $\mathrm{Hg}$ to polar snow packs through AMDEs during and after snow melt. The reduction and subsequent re-emission of a fraction of $\mathrm{Hg}$ from the snow pack is largely believed to occur through photochemical processes (Lalonde et al., 2002). King and Simpson (2001) have shown that solar irradiation can effectively penetrate the first few centimeters of the snow pack, possibly leading to photoreduction of $\mathrm{Hg}$ complexes contained therein. The interaction of microbes within the surface grains of the snow pack and the $\mathrm{Hg}$ contained therein is also of interest during this critical period (Amato et al., 2007). Research has been undertaken to further investigate the interaction of micro-organisms within the water layer around the snow grains that can form strong complexes with metals (Döppenschmidt and Butt, 2000; Ariya et al., 2002a; Krembs, 2006). The resultant melt water will then likely contain $\mathrm{Hg}$ bound to organic material that could thereafter enter the food chain. Finally, measurement techniques such as investigating the presence of $\mathrm{Hg}$ in polar firn (compressed snow) and ice cores provide essential environmental archives for studying the global $\mathrm{Hg}$ cycle (Vandal et al., 1993; Boutron et al., 1998; Mann et al., 2005).

Mercury is a contaminant of concern that is found in many different media in the polar environment. To address this, considerable work has been undertaken to develop methodologies to investigate the processes by which it transforms and cycles in this challenging environment. The following section outlines the many different methodologies that are employed to investigate $\mathrm{Hg}$ specifically in Polar Regions.

\section{Methodology employed to measure mercury in Polar Regions}

\subsection{Atmospheric mercury methodology}

Gaseous elemental mercury (GEM), reactive gaseous mercury (RGM) and particle associated mercury (PHg) are the most commonly measured and monitored $\mathrm{Hg}$ species (at times termed fractions) in Polar Regions because they play a role in the AMDE process and associated deposition to the snow and sea ice surface. GEM is the most predominant ( 90 99\%) of these forms of $\mathrm{Hg}$ found in the air (Schroeder and Munthe, 1995; Lin and Pehkonen, 1998). Currently, $\mathrm{Hg}(0)$ is the only gaseous $\mathrm{Hg}$ component that is easily and accurately measured in the field. The oxidized forms of $\mathrm{Hg}$ (including RGM and $\mathrm{PHg}$ ) exhibit different characteristics than $\mathrm{Hg}(0)$ in toxicity, transport and deposition to ecosystems and play an important role in understanding the fate and impact of $\mathrm{Hg}$ on the environment. Currently, RGM and PHg are operationally defined and no unambiguous identification has been possible to date.

Nearly all analyses of atmospheric $\mathrm{Hg}$, independent of fractionation or speciation, are performed using atomic absorption spectroscopy (AAS) or atomic fluorescence spectroscopy (AFS) as the principle method of detection. AAS instruments are simple, fairly inexpensive and small and are thus relatively mobile. AFS instruments, which tend to require more facilities (e.g. AC power and argon carrier gas), have greater sensitivity (Baeyens, 1992) allowing for an absolute detection limit as low as $0.1 \mathrm{pg}$ (Tekran Inc., Toronto, Canada). At times, this advantage in sensitivity is forsaken for applicability and practicality when sampling in Polar Regions.

Many recent advances in measurement techniques of these species have occurred in the last ten years to support investigations of AMDEs. The current state of the art in measurement techniques for these two species will be covered in this section. Table 2 provides a summary of the polar site locations and methods employed to measure atmospheric $\mathrm{Hg}$ species.

\subsubsection{Gaseous Elemental Mercury (GEM)}

Elemental mercury's ability to form alloys, especially amalgams, with noble metals offers a convenient way to collect air samples (Williston, 1968; Fitzgerald and Gill, 1979). Presently, amalgamation with gold is exclusively the principle method used to collect GEM (Schroeder and Munthe, 1995) for atmospheric measurements in Polar Regions. The basic principle of operation is i) pre-concentration of GEM onto a trap; ii) removal of the $\mathrm{Hg}$ from the trap by thermal desorption and iii) detection and quantification of the $\mathrm{Hg}$. This method has been previously presented in many publications, for example: (Ebinghaus et al., 1999; Munthe et al., 2001; Landis et al., 2002; Aspmo et al., 2005). Calibration 
Table 2. Summary of measurement sites, methodologies employed and atmospheric Hg species measured.

\begin{tabular}{|c|c|c|c|}
\hline Location & Analyte & Analytical method/ Instrumentation & Reference \\
\hline Alert & $\begin{array}{l}\text { GEM } \\
\text { HgP, RGM } \\
\text { TAM } \\
\text { Hg-Flux } \\
\text { TFM } \\
\text { TPM }\end{array}$ & $\begin{array}{l}\text { Tekran 2537A } \\
\text { Tekran 2537A/1130/1135 } \\
\text { Tekran 2537A/ CRPU } \\
\text { Gradient-micrometeorology } \\
\text { Manual TPM/TFM minisampler }\end{array}$ & $\begin{array}{l}\text { (Schroeder et al., 1998; Lu et al., 2001; } \\
\text { Steffen et al., 2002; Banic et al., 2003; } \\
\text { Slemr et al., 2003; Steffen et al., 2003a; } \\
\text { Steffen et al., 2003b; Ariya et al., 2004; } \\
\text { Lu and Schroeder, 2004; St. Louis et } \\
\text { al., 2005; Steffen et al., 2005; Cobbett } \\
\text { et al., 2007) }\end{array}$ \\
\hline Amderma & GEM & Tekran 2537A & (Steffen et al., 2005) \\
\hline Barrow & $\begin{array}{l}\text { GEM, RGM } \\
\text { HgP, RGM } \\
\text { RGM } \\
\text { Flux }\end{array}$ & $\begin{array}{l}\text { Tekran 2537A, manual denuders } \\
\text { Tekran 2537A/1130/1135 } \\
\text { REA developed system }\end{array}$ & $\begin{array}{l}\text { (Lindberg et al., 2001; Lindberg et al., } \\
\text { 2002; Skov et al., 2006; Tackett et al., } \\
\text { 2007; Brooks et al., 2006) }\end{array}$ \\
\hline Ny-Ålesund & $\begin{array}{l}\text { GEM, HgP, RGM } \\
\text { TAM } \\
\text { GEM }\end{array}$ & $\begin{array}{l}\text { Gardis } \\
\text { Tekran 2537/1130/1135, CRPU } \\
\text { TGM (manual gold trap) } \\
\text { RGM (manual) KCl coated denuders } \\
\text { HgP (manual) filters }\end{array}$ & $\begin{array}{l}\text { (Berg et al., 2003a; Berg et al., 2003b; } \\
\text { Wangberg et al., 2003; Aspmo et al., } \\
\text { 2005; Ferrari et al., 2005; Gauchard } \\
\text { et al., 2005; Sprovieri et al., 2005a, } \\
\text { 2005b; Fain et al., 2006b; Fain et al., } \\
\text { 2006a; Sommar et al., 2007) }\end{array}$ \\
\hline Resolute & GEM & Tekran 2537A & (Lahoutifard et al., 2005) \\
\hline Station Nord & GEM & $\begin{array}{l}\text { Tekran 2537A } \\
\text { Gardis }\end{array}$ & $\begin{array}{l}\text { (Ferrari et al., 2004a; Ferrari et al., } \\
\text { 2004b; Skov et al., 2004) }\end{array}$ \\
\hline Neumayer & GEM, RGM & $\begin{array}{l}\text { Tekran 2537A } \\
\text { Tekran 2537A /130 (prototype) }\end{array}$ & $\begin{array}{l}\text { (Ebinghaus et al., 2002; Temme et al., } \\
\text { 2003) }\end{array}$ \\
\hline Terra Nova & GEM, RGM & Tekran 2537A/1130 & (Sprovieri et al., 2002) \\
\hline $\begin{array}{l}\text { North Atlantic } \\
\text { Ocean }\end{array}$ & GEM, RGM, HgP & Tekran 2537A/1130/1135 & (Aspmo et al., 2006) \\
\hline Sub-Arctic & GEM & $\begin{array}{l}\text { Gardis } \\
\text { Tekran 2537A/1130/1135 }\end{array}$ & $\begin{array}{l}\text { (Dommergue et al., 2003b; Dommer- } \\
\text { gue et al., 2003a; Gauchard et al., } \\
\text { 2005; Steffen et al., 2005; Kirk et al., } \\
\text { 2006; Lahoutifard et al., 2006) }\end{array}$ \\
\hline
\end{tabular}

of GEM is well documented (Schroeder and Munthe, 1995; Aspmo et al., 2005; Temme et al., 2007); the instruments are calibrated by injecting a known quantity of $\mathrm{Hg}(0)$ from an external source maintained at a known temperature and pressure.

The method currently used in polar research to collect and measure GEM in ambient air is as follows: air is drawn through a quartz tube filled with gold beads or gold wires where the $\mathrm{Hg}$ amalgamates to the gold in the trap (Schroeder and Munthe, 1995). The gold trap is then thermally desorbed to a temperature greater than $500^{\circ} \mathrm{C}$ releasing the GEM from the trap into a carrier gas (usually ultra high purity argon or air). The $\mathrm{Hg}$ is then carried into a spectrometer (either AFS or AAS) for detection. In polar regions, some researchers re- port ambient air collected with this method as total gaseous mercury (TGM) which includes both the GEM and RGM species (Ebinghaus et al., 2002), however, if a filter (usually Teflon) is placed at the inlet of the sample line, it is most likely that RGM is removed and thus only GEM is collected (Steffen et al., 2002). Since the discovery of AMDEs, the research undertaken to collect and analyse GEM has predominantly employed the Tekran automated $2537 \mathrm{~A}^{\mathrm{TM}}$ (AFS) instrument or the automated Gardis (AAS) instrument (Lindberg et al., 2002; Sprovieri et al., 2002; Steffen et al., 2002; Dommergue et al., 2003a; Skov et al., 2004; Aspmo et al., 2005). Both these aforementioned instruments are automated and collect continuous or semi-continuous measurements, respectively. 


\subsubsection{Reactive Gaseous Mercury (RGM)}

Through the years, several efforts have been made to develop methods to accurately sample and quantify low concentrations of RGM, an inorganic $\mathrm{Hg}$ species, in the atmosphere (Brosset, 1987; Stratton and Lindberg, 1995; Xiao et al., 1997; Feng et al., 2000). The methods currently used in Polar Regions to measure RGM are outlined in the following paragraph.

The detailed methodology for collecting RGM (in Polar Regions) is described in Feng et al. (2000) and Landis et al. (2002). Briefly, $\mathrm{KCl}$ coated annular denuders are employed to collect RGM (primarily $\mathrm{HgCl}_{2}$ and/or $\mathrm{HgBr}_{2}$ ) from ambient air at a flow rate of 10 litres per minute for a minimum sampling time of $1 \mathrm{~h}$. For the commercial automated Tekran system, once the RGM is collected, the denuder is heated to $500^{\circ} \mathrm{C}$ in a stream of $\mathrm{Hg}$ free air. The thermally released $\mathrm{Hg}$ is passed over a quartz chip pyrolysis chamber (maintained between $525^{\circ} \mathrm{C}$ and $800^{\circ} \mathrm{C}$ ). The manual method for analysis of RGM is similar to this process without the quartz chip pyrolysis chamber (Aspmo et al., 2005). The RGM in the sample is thermally decomposed to $\mathrm{Hg}(0)$ and is transferred to a gold trap, usually inside a Tekran 2537A. This $\operatorname{Hg}(0)$ is then analysed and detected by AFS (as described above). RGM is usually detected in the low $\mathrm{pg} / \mathrm{m}^{3}$ concentration range but at times during polar spring, concentrations can increase to the low $\mathrm{ng} / \mathrm{m}^{3}$ range.

Calibration of this technique and the elucidation of the chemical speciation of RGM are part of ongoing discussions within the polar research community. Feng et al. (2003) evaluated a diffusion-type device to calibrate the denuder based system described above and found that this system, if modified, could be used for calibration. However, to the best of the authors' knowledge, no calibration system is available that can be used by the research community in Polar Regions to establish the accuracy of the RGM collected using this technique. Therefore, this significant limitation in the analytical capabilities of RGM detection must be prudently identified and considered when reporting information about RGM concentrations in Polar Regions. In addition, while $\mathrm{KCl}$ denuders are known to collect $\mathrm{HgX}_{2}(\mathrm{X}=$ halogen), the chemical speciation of RGM has yet to be determined. Therefore, at this time, RGM must be considered, at best, an operationally defined atmospheric species as presented in this publication.

\subsubsection{Particle associated Mercury $(\mathrm{HgP})$}

In general, the concentration of $\mathrm{Hg}$ on particles accounts for only a few percent of the total atmospheric $\mathrm{Hg}$ pool but some Arctic studies have shown that this few percent rises to approximately $40 \%$ during the springtime in Polar Regions (Lu et al., 2001; Steffen et al., 2003a). To collect $\mathrm{HgP}$ in Polar Regions, air is passed through a suitable filter medium that traps the airborne particles (Schroeder and Munthe, 1995). At present, filter methods are most com- monly applied whereby a variety of different filter materials are used, including Teflon, cellulose, quartz and glass fibre (Lu and Schroeder, 1999). Further, wet digestion (Keeler et al., 1995) or pyrolysis (Schroeder and Munthe, 1995; Lu et al., 1998) is used to release the captured $\mathrm{HgP}$, followed by detection using CV-AFS or AFS, respectively. For atmospheric $\mathrm{Hg}$ speciation in Polar Regions, quartz filters are commonly used. The procedure using the commercially developed Tekran 1135 is as follows: $\mathrm{HgP}$ is collected onto a quartz filter and is thermally released from the filter by heating it to approximately $800^{\circ} \mathrm{C}$. The released sample is pyrolysed by passing the air stream through quartz chips also maintained at $800^{\circ} \mathrm{C}$ (Landis et al., 2002). Manual methods for analysis have also been employed with a similar procedure except the quartz chips chamber is not employed (Aspmo et al., 2005). The thermal decomposition to GEM is followed by AFS detection (Lu et al., 1998; Landis et al., 2002).

\subsubsection{Total Atmospheric Mercury (TAM)}

TAM species present in ambient air are determined by pyrolysing the air prior to introducing the air stream into a $\mathrm{Hg}$ analyzer. A cold regions Pyrolysis unit (CRPU) was specially designed to measure TAM under Arctic conditions as a front end unit to the Tekran 2537A (Steffen et al., 2002; Banic et al., 2003; Aspmo et al., 2005). Incoming air is heated and maintained at $900^{\circ} \mathrm{C}$ in a quartz tube filled with quartz chips. All gas-phase Hg (both GEM and RGM) and most particle associated organic and inorganic $\mathrm{Hg}$ are converted to GEM within the CRPU and are then detected and analysed using AFS (Steffen et al., 2002; Steffen et al., 2003a; Lu and Schroeder, 2004).

\subsection{Flux measurement methods}

The exchange of $\mathrm{Hg}$ to and from a surface is termed a "flux". Fluxes of RGM or GEM are expressed as emission or deposition rates, generally in nanograms per meter squared per unit of time (usually seconds or hours). Typical sign convention treats an emission as a positive flux and a deposition as a negative flux. From the flux and air concentration information, a deposition velocity can be calculated and $\mathrm{Hg}$ transformation mechanisms are then analysed. Several flux measurement methods have employed micro meteorological techniques to measure air-snow surface exchange of GEM (Lindberg et al., 2002; Cobbett et al., 2007; Brooks et al., 2006) and air-snow surface exchange of RGM (Lindberg et al., 2002; Skov et al., 2006). As well, indicative methods such as flux chambers (Schroeder et al., 2003; Ferrari et al., 2005; Sommar et al., 2007) and vertical gradient measurements have been employed to infer the direction of fluxes in Polar Regions (Steffen et al., 2002; Schroeder et al., 2003; Sommar et al., 2007). 


\subsubsection{Micrometeorological methods}

There are three primary micrometeorological (micromet) methods employed to measure the atmospheric flux of trace compounds: i) the eddy covariance method; ii) relaxed eddy accumulation (REA) and iii) flux gradient methods including the modified bowen ratio (MBR) method - most commonly used in $\mathrm{Hg}$ measurements. Micromet methods involve the measurement of fluctuations in wind speed and wind direction to determine turbulent transfer coefficients which are referred to as "eddy diffusivities". Micromet methods assume that turbulent mixing dominates over simple diffusion and combines the measured vertical transport rates in near surface air (turbulence), in methods i) and ii), with concentration fluctuations and, in method iii), gradient of $\mathrm{Hg}$ species. In this way the average surface fluxes over an area around the sampling location known as the flux footprint or fetch are calculated.

The most direct of these methods is eddy covariance which involves the measurement of instantaneous high frequency fluctuations in wind speed about its mean in the vertical using a fast-response sonic anemometer and simultaneously measuring high frequency fluctuations in the concentration of a trace species called "eddy correlation". This is not possible for $\mathrm{Hg}$ given the lack of fast or high frequency measurement methods. Recent advances in applications of optical atmospheric methods such as LIDAR for the determination of atmospheric $\mathrm{Hg}$ fluxes (Bennet et al., 2006) or MAX-DOAS for $\mathrm{BrO}$ (Hönninger and Platt, 2002) may lead to future application of this sensitive technique to $\mathrm{Hg}$. At present, these optical methods can only be applied in areas with high $\mathrm{Hg}(0)$ concentrations (i.e. near chlor-alkali plants) and are therefore not suitable for Polar Regions.

The second micromet method, relaxed eddy accumulation (REA), was applied toward measuring $\mathrm{Hg}(0)$ fluxes (Cobos et al., 2002; Olofsson et al., 2005). The technique has been employed for RGM fluxes in the Arctic at Barrow, Alaska and Station Nord, Greenland (Lindberg et al., 2002; Goodsite, 2003; Skov et al., 2006). REA "relaxes" the requirement for instantaneous gas analysis by differentially collecting the trace compound in air over time followed by analysis of the compound. In the case of RGM, the collector used is a manual or automated $\mathrm{KCl}$ denuder sampling system. For GEM the collector is a gold trap as described earlier in Sect. 3.1.1. The limitation of the REA and the MBR methods is that $\mathrm{Hg}$ is accumulated over time and thus fast or high frequency information of the species is forsaken.

The third method, flux gradient, assumes that turbulence transports all gaseous species equally. Using this assumption, the measurement of a concentration gradient of $\mathrm{Hg}$ at two or more heights above a surface concurrently with micromet measurements can be used to quantify the vertical turbulence mixing rate. These variables are combined to calculate the flux of $\mathrm{Hg}$ between a surface and the atmosphere. This method has been successfully employed in the Arctic for measuring the flux of GEM between the air and the snow pack (Cobbett et al., 2007). A type of flux gradient method, the modified Bowen ratio technique, calculates a fast eddy correlation flux measurement for an easily measured tracer flux (e.g. carbon dioxide, water vapour), a gradient of the eddy correlation tracer and the $\mathrm{Hg}$ species at the same heights in order to calculate the flux. This method and has been successfully employed in the Arctic (Skov et al., 2006; Brooks et al., 2006) for Hg flux measurements between the snow pack and the atmosphere.

\subsubsection{Chamber methods}

The use of chambers to measure the flux processes of $\mathrm{Hg}$ in Polar Regions is beneficial because they are sensitive to environmental conditions and also to instrumental parameters such as the flushing flow rate (Wallschlager et al., 1999) and ventilation, and thus may be applied to measurements over the snow surface (Ferrari et al., 2005). Chamber methods employ a small encapsulated surface area (e.g. the snow pack) and determine the rate of change of the $\mathrm{Hg}$ emissions in the head space with time. There are some limitations with using chamber methods in Polar Regions which include a limited chamber footprint (the area that the chamber covers), isolation of the surface from the effects of atmospheric turbulence and the chamber may act as a greenhouse and modify the temperature and humidity of the snow surface thus altering the properties of the snow and the natural behaviour of $\mathrm{Hg}$ within that medium.

To further the study of snow to air transfers of GEM, laboratory manipulation studies have involved the collection of bulk snow from polar areas and subjected them to a variety of parameters (e.g. solar radiation and temperature) within a controlled environment to determine effects of these parameters on the flux of $\mathrm{Hg}$ from the snow (Lalonde et al., 2002; Poulain et al., 2004; Lahoutifard et al., 2006; Dommergue et al., 2007). These atmospheric laboratory and modelling methods will be discussed in subsequent sections.

3.3 Aqueous $\mathrm{Hg}$ measurement techniques employed in the Arctic

Mercury is usually measured in polar aquatic systems at ultra-trace levels. Table 3 provides a summary of aqueous measurements that have been made at various locations in the Arctic, including a brief overview of the analytical method used for each study.

\subsubsection{Total mercury in water samples}

Total mercury $(\mathrm{THg})$ concentrations in surface water have been reported in levels ranging from subnanogram to more than 1 nanogram per litre in the North Atlantic Ocean (Mason et al., 1998), Arctic Russian estuaries (Coquery et al., 1995b) and a high Arctic watershed (Semkin et al., 2005). Maximum concentrations have been measured around 10 
Table 3. Summary of aqueous mercury measurement methods in the Arctic.

\begin{tabular}{|c|c|c|c|c|}
\hline $\begin{array}{l}\text { Analyte \& } \\
\text { associated reference }\end{array}$ & Sampling source & Location & Analytical method & $\begin{array}{l}\text { Detection } \\
\text { limit }\end{array}$ \\
\hline \multicolumn{5}{|l|}{ Total-Hg } \\
\hline (Semkin et al., 2005) & Lake & $\begin{array}{l}\text { Amituk Lake, Cornwallis Island, } \\
\text { Nunavut, Canada }\end{array}$ & $\begin{array}{l}\text { oxidation by hydrogen peroxide, reduction by sodium } \\
\text { borohydride, trapping on gold coated sand, AFS detec- } \\
\text { tion }\end{array}$ & $0.08 \mathrm{ng} / \mathrm{L}$ \\
\hline (Aspmo et al., 2006) & Ocean & North Atlantic, $75-85^{\circ} \mathrm{N}$ & $\begin{array}{l}\text { preservation with } \mathrm{HCl} \text {, digestion by } \mathrm{BrCl} \text {, reduction by } \\
\text { stannous chloride, AFS detection }\end{array}$ & $0.05 \mathrm{ng} / \mathrm{L}$ \\
\hline (Sommar et al., 2007) & Fjord & Kongfjorden, Svalbard, Norway & Preservation with $\mathrm{HCl}$ & \\
\hline (Mason et al., 1998) & Ocean & North Atlantic, $50-70^{\circ} \mathrm{N}$ & $\begin{array}{l}\text { acidified sample }(\mathrm{HCl}) \text {, allowed for digestion }(72 \mathrm{~h}) \text {, re- } \\
\text { duction with } \mathrm{SnCl}_{2}, \mathrm{CVAFS} \text { detection }\end{array}$ & \\
\hline (Loseto et al., 2004a) & Lake & $\begin{array}{l}8 \text { lakes north of Resolute Bay, Cornwallis } \\
\text { Island, Nunavut, Canada }\end{array}$ & $\begin{array}{l}\text { Preservation with } \mathrm{BrCl}, \mathrm{SnCl}_{2} \text { reduction, CVAFS (EPA } \\
\text { Method 1631) }\end{array}$ & $0.25 \mathrm{ng} / \mathrm{L}$ \\
\hline $\begin{array}{l}\text { (Hammerschmidt et al., } \\
\text { 2006a) }\end{array}$ & Lake & $\begin{array}{l}4 \text { lakes near Toolik Field Station, Arctic } \\
\text { Alaska, US }\end{array}$ & $\begin{array}{l}\text { analysis within } 25 \mathrm{~h} \text { of collection, digestion with } \mathrm{BrCl} \text {, } \\
\text { CVAFS detection }\end{array}$ & $0.01 \mathrm{ng} / \mathrm{L}$ \\
\hline (St. Louis et al., 2005) & Pond and lake & $\begin{array}{l}\text { Northern Ellesmere Island, Nunavut, } \\
\text { Canada }\end{array}$ & $\begin{array}{l}\text { Preservation with conc. trace-metal grade } \mathrm{HCl} \text { equal to } \\
0.2 \% \text { (vol.), CVAFS detection with Tekran } 2500\end{array}$ & $0.05 \mathrm{ng} / \mathrm{L}$ \\
\hline (Coquery et al., 1995a) & River and estuary & $\begin{array}{l}\text { Ob, Yenisei and Lena river and their estu- } \\
\text { aries to Kara Sea and Laptev Sea, Siberian } \\
\text { Arctic, Russia }\end{array}$ & $\begin{array}{l}\text { reduction by } \mathrm{NaBH}_{4} \text {, double gold amalgamation, } \\
\text { CVAFS detection }\end{array}$ & $0.14 \mathrm{ng} / \mathrm{L}$ \\
\hline \multicolumn{5}{|l|}{ DGM } \\
\hline (Sommar et al., 2007) & Fjord & Kongfjorden, Svalbard, Norway & $\begin{array}{l}\text { purge and trap with inert gas }\left(0.3 \mathrm{~L} \mathrm{~min}^{-1}\right) \text {, collected } \\
\text { on Au-trap, CVAFS detection }\end{array}$ & \\
\hline (Mason et al., 1998) & Ocean & North Atlantic Ocean, $50-70^{\circ} \mathrm{N}$ & purge and trap on gold trap, CVAFS detection & $0.04 \mathrm{ng} / \mathrm{L}$ \\
\hline (Fitzgerald et al., 2005) & Lake & $\begin{array}{l}5 \text { lakes near Toolik Field Station, Arctic } \\
\text { Alaska, US }\end{array}$ & $\begin{array}{l}\text { purge and trap with } \mathrm{Hg} \text {-free } \mathrm{N}_{2} \text { gas in borosilicate bub- } \\
\text { bler to gold-coated sand trap, detection by CVAFS }\end{array}$ & \\
\hline (Tseng et al., 2004) & Lake & Ten lakes, Arctic Alaska, US & $\begin{array}{l}\text { semiautomatic purge and trap }\left(1 \mathrm{~L} \mathrm{~min}^{-1} \mathrm{~N}_{2}\right) \text {, two- } \\
\text { stage amalgamation and flow-injection technique, AFS- } \\
\text { detection }\end{array}$ & $6 \mathrm{pg} / \mathrm{L}$ \\
\hline \multicolumn{5}{|l|}{$\mathrm{Hg}(\mathrm{II})$ - reactive } \\
\hline (Mason et al., 1998) & Ocean & North Atlantic, $50-70^{\circ} \mathrm{N}$ & $\begin{array}{l}\text { direct reduction with acidic }(2.6 \mathrm{~N} \mathrm{HCl}) 10 \% \text { stannous } \\
\text { chloride, CVAFS detection }\end{array}$ & $0.35 \mathrm{pM}$ \\
\hline \multicolumn{5}{|l|}{$\mathrm{MeHg}$} \\
\hline (Loseto et al., 2004a) & Lake & $\begin{array}{l}8 \text { lakes north of Resolute Bay, Cornwallis } \\
\text { Island, Nunavut, Canada }\end{array}$ & $\begin{array}{l}\text { SPE on sulfide columns, acidic } \mathrm{KBr} \text { elusion, GC with } \\
\text { AFS detection }\end{array}$ & $0.02 \mathrm{ng} / \mathrm{L}$ \\
\hline (Mason et al., 1998) & Ocean & North Atlantic Ocean, $50-70^{\circ} \mathrm{N}$ & $\begin{array}{l}\text { Distillation, ethylation with sodium tetraethylboarate, } \\
\text { GC with AFS detection }\end{array}$ & $0.5 \mathrm{pM}$ \\
\hline $\begin{array}{l}\text { (Demuth and Heumann, } \\
\text { 2001) }\end{array}$ & Ocean & North Atlantic Ocean & $\begin{array}{l}\text { Ethylation/propylation, purging, cryofocussing, GC- } \\
\text { ICP-IDMS }\end{array}$ & $0.03 \mathrm{pg} / \mathrm{mL}$ \\
\hline $\begin{array}{l}\text { (Hammerschmidt et al., } \\
\text { 2006a) }\end{array}$ & Lake & Toolik Lake, Arctic Alaska, US & $\begin{array}{l}\text { Ethylation, concentration on Tenax, flow injection GC } \\
\text { CVAFS }\end{array}$ & $0.004 \mathrm{ng} / \mathrm{L}$ \\
\hline (St. Louis et al., 2005) & Ponds and lake & $\begin{array}{l}\text { Northern Ellesmere Island, Nunavut, } \\
\text { Canada }\end{array}$ & $\begin{array}{l}\text { Preserve with concentrated trace metal grade } \mathrm{HCl}(0.2 \% \\
\text { vol.), distillation, aqueous phase ethylation, CVAFS }\end{array}$ & $0.02 \mathrm{ng} / \mathrm{L}$ \\
\hline (Leitch et al., 2007) & Lake & Lower Mackenzie River, Canada & Capillary GC-AFS & $0.02 \mathrm{ng} / \mathrm{L}$ \\
\hline \multicolumn{5}{|l|}{$\mathrm{Me}_{2} \mathbf{H g}$} \\
\hline (Mason et al., 1998) & Ocean & North Atlantic, $50-70^{\circ} \mathrm{N}$ & Purge and trap on Carbotrap column, CVAFS detection & $10 \mathrm{fM}$ \\
\hline \multicolumn{5}{|c|}{ Photoreduction/photooxidation } \\
\hline (Amyot et al., 1997) & lake & $\begin{array}{l}\text { Amituk Lake, Merreta Lake, North } \\
\text { Lake, Arctic wetland, Cornwallis Island, } \\
\text { Nunavut, Canada }\end{array}$ & $\begin{array}{l}\text { Time series of DGM in bottles incubated under solar } \\
\text { radiation, and submitted to various treatments (filters, } \\
\mathrm{H}_{2} \mathrm{O}_{2} \text {, fulvic acids) }\end{array}$ & \\
\hline (Poulain et al., 2004) & pond & Cornwallis Island, Nunavut, Canada & $\begin{array}{l}\text { Time series of DGM in bottles incubated under solar } \\
\text { radiation. }\end{array}$ & \\
\hline (Tseng et al., 2004) & lake & 10 lakes, Arctic Alaska, US & & \\
\hline
\end{tabular}


nanograms per litre in Canadian Arctic ponds and lakes (Loseto et al., 2004b; St. Louis et al., 2005). In general, water samples are collected in Teflon or glass bottles containing a $0.4-0.5 \%$ acidic solution of $\mathrm{HCl}$ in order to reduce contamination and to preserve the $\mathrm{Hg}$ in the sample (Parker and Bloom, 2005). As well, samples can be collected using high density polyethylene bottles (Hall et al., 2002) should Teflon not be available. $\mathrm{BrCl}$ is added to the sample after collection to digest the $\mathrm{Hg}$ in the water followed by reduction of the $\mathrm{Hg}$ with stannous chloride $\left(\mathrm{SnCl}_{2}\right)$. Pre-concentration of $\mathrm{Hg}$ onto gold traps by sparging the sample to release $\mathrm{Hg}(0)$ from the solution follows this reduction and the $\mathrm{Hg}$ contained in this sample is then detected using CVAFS (Loseto et al., 2004a; Aspmo et al., 2006; Hammerschmidt et al., 2006b). Semkin et al. (2005) used hydrogen peroxide for oxidative digestion and both Semkin et al. (2005) and Coquery et al. (2005) reduced $\mathrm{Hg}$ (II) species with sodium borohydride. Detection limits ranging from 0.01 to $0.25 \mathrm{ng} / \mathrm{L}$ are reported in the aforementioned papers.

\subsubsection{Monomethyl mercury and dimethyl mercury in water samples}

Aqueous monomethyl mercury (MeHg) concentrations are reported in levels from a few tenths of a picogram per litre in Arctic Lakes (St. Louis et al., 2005; Hammerschmidt et al., 2006a) and the Mackenzie river basin and mainstream (Leitch et al., 2007) to several hundreds of picograms per litre in small Arctic ponds (St. Louis et al., 2005) and the North Atlantic Ocean (Mason et al., 1998).

In most applications $\mathrm{MeHg}$ was determined by aqueous phase ethylation with sodium tetraethylborate, subsequent concentration either by cryofocusing with liquid nitrogen (Demuth and Heumann, 2001) or by collection on Tenax traps (Hammerschmidt et al., 2006a), separation by capillary gas chromatography and finished by AFS detection (Mason et al., 1998; St. Louis et al., 2005; Leitch et al., 2007). Solid phase extraction on sulfide columns followed by acidic $\mathrm{KBr}$ elution before GC separation with AFS detection has been employed (Loseto et al., 2004a). In addition, propylation instead of ethylation was successfully used coupled with ICP/GC where the method detection limits were reported in the range of $20 \mathrm{pg} / \mathrm{L}$ (Demuth and Heumann, 2001).

$\mathrm{Me}_{2} \mathrm{Hg}$ was analyzed by purge and trap technique on Carbotrap ${ }^{\circledR}$ columns and subsequent thermal desorption, separation by gas chromatography and AFS detection (Mason et al., 1998).

\subsubsection{Dissolved gaseous mercury and reactive mercury in water samples}

Dissolved gaseous mercury (DGM) can be produced in freshwater and marine environments through biotic and abiotic processes. DGM is composed of volatile $\mathrm{Hg}$ species similar to $\mathrm{Hg}(0)$ and $\mathrm{Me}_{2} \mathrm{Hg}$, both of which are characterized by relatively high Henry's law coefficients (Schroeder and Munthe, 1995). Reported concentrations of DGM in Arctic Alaskan lakes (Tseng et al., 2004; Fitzgerald et al., 2005), the North Atlantic Ocean (Mason et al., 1998) and a Spitsbergen fjord (Sommar et al., 2007) range between 10 to more than $100 \mathrm{pg} / \mathrm{L}$. In general, DGM is collected and measured by purging water samples with an inert gas which releases the volatile $\mathrm{Hg}$ species from the water sample. The $\mathrm{Hg}$ is then pre-concentrated onto a gold adsorber (purge \& trap technique) and analyzed by CVAFS (Mason et al., 1998; Tseng et al., 2004; Fitzgerald et al., 2005; Sommar et al., 2007). Gårdfeldt et al. (2002) show some promising methodologies employing an in situ impinger technique for continuous automatic measurements for DGM and compared them with manual methods.

Reactive $\mathrm{Hg}$ in water samples consists of the fraction of $\mathrm{Hg}$ that is directly reduced from the water sample by stannous chloride and subsequently analysed by purge \& trap. When corrected for the presence of DGM, it is designated as $\mathrm{Hg}$ (II) because the sample consists largely of inorganic $\mathrm{Hg}$ complexes (Mason et al., 1998). Further, Tseng et al. (2004) defines another $\mathrm{Hg}$ species in water samples as dissolved labile Hg (DLM). This DLM is found in $<0.45 \mu \mathrm{m}$-filtered aliquots and is reduced by stannous chloride.

\subsection{Air-water exchange}

There has been only a small number of air-water exchange studies of $\mathrm{Hg}$ conducted in Polar Regions. Considering the strong seasonal and spatial variation in the magnitude and direction of $\mathrm{Hg}$ fluxes, it is certainly an important component. There are many different approaches to measuring flux and some are more qualitative rather than quantitative. The most commonly used technique to measure the Hg airsurface flux is eddy correlation described in Sect, 3.2. However, this micrometeorological method requires air sensors with a response time of at least several $\mathrm{Hz}$. A feasible sensor for measuring the air-water exchange of $\mathrm{Hg}(0)$ has been reported (Bauer et al., 2002; Bauer et al., 2003). Micrometeorological techniques (MBR or REA) have been implemented in the field to measure air surface fluxes of GEM and RGM from various surfaces (e.g. Meyers et al., 1996; Cobos et al., 2002; Olofsson et al., 2005; Skov et al., 2006).

\subsection{Photoreduction and photooxidation in fresh and sea water}

Photoredox experiments are usually carried out using batch or flow-through incubations. Batch incubations are conducted by incubating water samples under solar radiation in Teflon bottles (or quartz tubes) for short periods of time (between 1 and $8 \mathrm{~h}$ ). During such incubations, some samples are wrapped in various light filters, or kept in the dark, in order to isolate the effect of different wavebands (UV-A, UV-B, visible). Samples are occasionally spiked with reactive oxy- 
gen species (Amyot et al., 1997), dissolved organic carbon (Amyot et al., 1997); humic acids (Costa and Liss, 2000) or other compounds potentially involved in photoreduction reactions such as Fe(III) (Zhang and Lindberg, 2001). Photoreduction and photooxidation are known to occur simultaneously. Since photoreduction is usually the dominant reaction, these studies primarily report apparent photoreduction rates $\left(k_{\text {apparent }}=k_{\text {reduction }}-k_{\text {oxidation }}\right)$. Typically, a plateau in the concentration of $\operatorname{Hg}(0)$ over time is observed after a few hours of incubation, when equilibrium is reached between reduction and oxidation. Some studies have modified the samples with aqueous $\mathrm{Hg}(0)$ at the start of the incubation in order to calculate a photooxidation rate $-k_{\text {oxidation }}$ (Lalonde et al., 2004). The flow-through samples are exposed to solar radiation and are continuously purged of their $\mathrm{Hg}(0)$ which allows the calculation of actual photoreduction rates $-k_{\text {reduction }}$ (Costa and Liss, 2000; O'Driscoll et al., 2006). Indeed, since $\mathrm{Hg}(0)$ is removed for quantification as the reaction proceeds, there is no substrate for oxidation; thus the reduction rate can be calculated. The emergence of analytical systems for the in situ continuous analysis of DGM will provide another way to relate DGM production and loss to solar radiation (Amyot et al., 2001; Gårdfeldt et al., 2002).

Other mechanistic reaction kinetic studies have also been performed in order to discriminate between oxidation and reduction reactions that may occur simultaneously in this environment (Gårdfeldt et al., 2001; Gårdfeldt and Jonsson, 2003). Reactions between $\mathrm{Hg}(0)$ and $\mathrm{O}_{3(\mathrm{aq})}$, as well as $\mathrm{Br}_{2(\mathrm{aq})}$ and $\mathrm{Cl}_{2(\mathrm{aq})}$, have been studied in the laboratory by relative rate (scavenger) hydrolysis titration techniques (Munthe, 1992; Lin and Pehkonen, 1998; Wang and Pehkonen, 2004). Finally, $\operatorname{Hg}(0)$ photoradical aqueous reactions between $\mathrm{Hg}(0)+\mathrm{OH}$ have been studied under laboratory conditions and are reported to be fast (Lin and Pehkonen, 1998; Gårdfeldt et al., 2001).

\subsection{Snow sampling and analytical methods}

Snow and ice provide the substrate upon which $\mathrm{Hg}$ is transferred from the atmosphere to polar ecosystems. Thus, a better understanding of the scavenging, storage and ultimate fate of $\mathrm{Hg}$ in the polar snow pack is a major research focus. Snow or ice sample collection in Polar Regions generally makes use of the "clean hands - dirty hands" protocol as described by Patterson and Settle (1976). Special attention must be paid to minimise contamination of the samples by the sampling personnel, their equipment and the surrounding environment (e.g. building influence, biological matter). Tests in the field for recovery and blanks are performed to ensure that the sampling procedure is free of contamination. In all cases, clean nitrile or latex powder free gloves and dust-free clothing must be worn throughout the sample collection period. Utmost care must be taken to ensure that snow sampling personnel cover their mouths, hair and noses to prevent contamination.
Snow surface sampling does not require any additional specific precautions but sampling from a snow pit to recover specific snow layers, precipitation or wind events requires further preparation. Prior to collecting snow samples a series of detailed measurements should be made to characterize the snow pack and determine what is represented at a given location (Sturm and Liston, 2003). A snow measuring pit, roughly two square meters, should be excavated to the desired depth and heterogeneity can be assessed by excavating several pits in a given area. Snow layer measurements are collected where each identifiable layer is characterized by its thickness, lateral consistency and snow grain features. The type and size of snow grains from each layer can be characterised using a 20X optical microscope. The most widely accepted classifications for snow have been documented (Colbeck, 1986; Jones et al., 2001). Following identification of unique snow layers and grain types a sampling plan is developed. Once the snow pack and snow layer characteristics have been identified, samplers put on their clean protective gear and move $100 \mathrm{~m}$ upwind of the initial snow pit location to excavate a pit from which trace element samples may be collected.

Ice and ice core sampling is performed with drills. To reduce contamination from the drill on the sample, the outer layers of the core are mechanically scraped off in a cold lab in clean room conditions (Planchon et al., 2004). Samples should be stored in glass, Teflon or sometimes high density polyethylene bottles that have been rigorously cleaned according to United States Environmental Protection Agency protocols (EPA, 1996) and in Parker and Bloom (2005).

Once snow has been collected using the above outlined clean procedures, $\mathrm{Hg}$ species are analysed by several techniques that have been well described in the literature (Gill and Fitzgerald, 1987; Bloom and Fitzgerald, 1988; Amyot et al., 2004; Planchon et al., 2004). The low levels of $\mathrm{Hg}$ species in snow and ice require the use of sensitive and reproducible techniques. These techniques employ chemical treatment of the sample followed by chemical transformation and detection. The most common $\mathrm{Hg}$ species that are found in polar snow will be described in detail in Sect. 6 . Samples are melted and analysed by the same techniques as those applied to fresh and sea water samples described in Sect. 3.3.1 (Amyot et al., 2004). Reactive mercury, methyl mercury $(\mathrm{MeHg})$ and total mercury $(\mathrm{THg})$ are measured in water from melted snow and ice samples using ultra-sensitive detectors such as CVAFS (Gill and Fitzgerald, 1987; Bloom and Fitzgerald, 1988) and, more recently, with inductively coupled plasma mass spectrometry (Eyrikh et al., 2003; Planchon et al., 2004; Mann et al., 2005). Prior to detection, reactive and total $\mathrm{Hg}$ samples are chemically treated. Reactive $\mathrm{Hg}$ is first reduced with $\mathrm{SnCl}_{2}$ to form $\mathrm{Hg}(0)$ which is separated through sparging from the matrix. The $\mathrm{Hg}$ content in the sample is then measured with the techniques presented above. Mercury that is strongly bound to particles (i.e. organic matter and that which is not reduced by the application 
of $\mathrm{SnCl}_{2}$ ) is treated with $\mathrm{BrCl}$ prior to $\mathrm{SnCl}_{2}$ treatment to allow for the measurement of THg in the sample. Methyl mercury is measured by coupling gas chromatography with inductively coupled plasma (Jitaru et al., 2003) or atomic fluorescence spectrometry following a solid-phase extraction on sulfydryl-cotton fibre (SCF) and an acidic-potassium bromide elusion (Lahoutifard et al., 2005) based on Cai et al. (2000).

As well, GEM in the interstitial snow pack air can be measured by a variety of techniques. For example, inserting Teflon tubing into the snow pack (Steffen et al., 2003b), using Teflon probes (Dommergue et al., 2003c) or sniffers (St. Louis et al., 2005). Using these samplers at different depths within the snow pack and coupling the measurements with ancillary information (e.g. temperature), the variation of GEM in the air of the snow can be determined.

\section{Atmospheric Mercury in Polar Regions and Atmo- spheric Mercury Depletion events (AMDEs)}

\subsection{Trends of atmospheric mercury}

Long-term measurements of atmospheric $\mathrm{Hg}$ suggest that concentrations increased from the late 1970 s to a peak in the 1980s, decreased to a minimum around 1996 and have been nearly constant since that time (Slemr et al., 2003). The long-term data used for the reconstruction of the worldwide trend of GEM since 1977 were collected at several global background sites in both hemispheres. Continuous long-term TGM measurements in Polar Regions using highly time-resolved automatic monitors (described in Sect. 3.1) have been carried out exclusively at several observatory sites within the Northern Hemisphere. For this discussion, only time series from Polar Regions with more than 5 years of continuous measurements are considered. These include measurements from Ny-Ålesund, Norway (19942000 [manual samples]; 2000-2002 [automated samples]) and Alert, Canada (1995-2002/5) (Berg et al., 2004; Temme et al., 2004; Kim et al., 2005; Steffen et al., 2005; Temme et al., 2007). Techniques of series analysis such as seasonal decomposition and statistical tools for trend analysis were applied to these datasets. Both of these time series showed no evidence of annual long-term trends during each respective monitoring period. In the springtime, highly variable GEM concentrations as well as the lowest median concentrations of all the seasons are reported by Steffen et al. (2005) for each observed year. This trend in the springtime concentration is a result of AMDEs that are known to occur in these regions. While the low springtime median concentrations at Alert revealed no significant trend $(95 \% \mathrm{CI})$ from 1995 to 2002, the summer GEM concentrations indicated a statistically significant (95\% CI) decrease from 1995 to 2002. Mercury concentrations measured in the summer were higher than the springtime at Alert perhaps due to the emission of
$\mathrm{Hg}$ from tundra and snow surfaces (Steffen et al., 2005). This decreasing summer trend in GEM concentration is in contrast to a more recent report of a trend at Alert, between 1995 and 2005, where it is shown that no statistically significant trend for each season was found (Temme et al., 2007). The authors hypothesize that this change in trends may be due to higher re-emission from the oceans coupled with effects from rising air temperatures during Arctic summer and effects from decreasing European emission rates during that time period.

Currently, there are no other long term measurements published of $\mathrm{Hg}$ in the atmosphere from Polar Regions. The authors encourage more long term measurements of GEM and other atmospheric $\mathrm{Hg}$ species in Polar Regions as these measurements can yield critical information to better understand the processes involved in the cycling of $\mathrm{Hg}$ in the polar atmosphere. Further, two major drivers of $\mathrm{Hg}$ deposition to the Arctic are currently undergoing dramatic change. Firstly, the climate is warming which is changing the timing and extent of sea ice and its coverage (Serreze et al., 2003; Stroeve et al., 2005). The effects of shifts in sea ice on $\mathrm{Hg}$ scavenging by snow and ice and on halogen emission from open water and sea ice regions are unknown. Warming is also dramatically affecting the seasons with winter coming later and spring melt coming earlier. Thus, the amount of time between $\mathrm{Hg}$ deposition during AMDEs and $\mathrm{Hg}$ mobilization during spring melt are shrinking. This could affect the amount of reemission of $\mathrm{Hg}$ from the snow pack but no models or measurements investigating this have been made. Secondly, coal and fossil fuel combustion in Asia, a major global source of $\mathrm{Hg}$, is expected to increase up to $350 \%$ between 1990 levels and 2020 (van Aardenne et al., 1999). The effects of these increasing emissions on AMDE processes and the long term deposition of $\mathrm{Hg}$ to the Polar Regions will only be discernible if long term measurements are collected at numerous locations.

\subsection{Atmospheric Mercury Depletion Events (AMDEs)}

The first annual time series of high-resolution atmospheric $\mathrm{Hg}$ vapour data was collected in the Arctic at Alert, Nunavut, Canada in 1995 (Schroeder et al., 1998) as shown in Fig. 2. It was found that after sunrise the GEM concentrations underwent extraordinary fluctuations, decreasing at times from values approximately $1.7 \mathrm{ng} / \mathrm{m}^{3}$ to values less than $0.1 \mathrm{ng} / \mathrm{m}^{3}$ within periods of $24 \mathrm{~h}$ or less. This behaviour runs counter to what is expected for an air pollutant characterized by a long atmospheric residence time (Schroeder and Munthe, 1995). The unique environmental condition at Alert that appeared to initiate this unusual behaviour was the sudden exposure to solar radiation in early March after approximately 5 months of total darkness. Further measurements at Alert in 1996 (to the present present) corroborated the distinctive behaviour of GEM after polar sunrise and revealed a strong correlation between GEM and ground level ozone concentrations as shown in Fig. 2 (Schroeder et al., 1998). During and after polar 


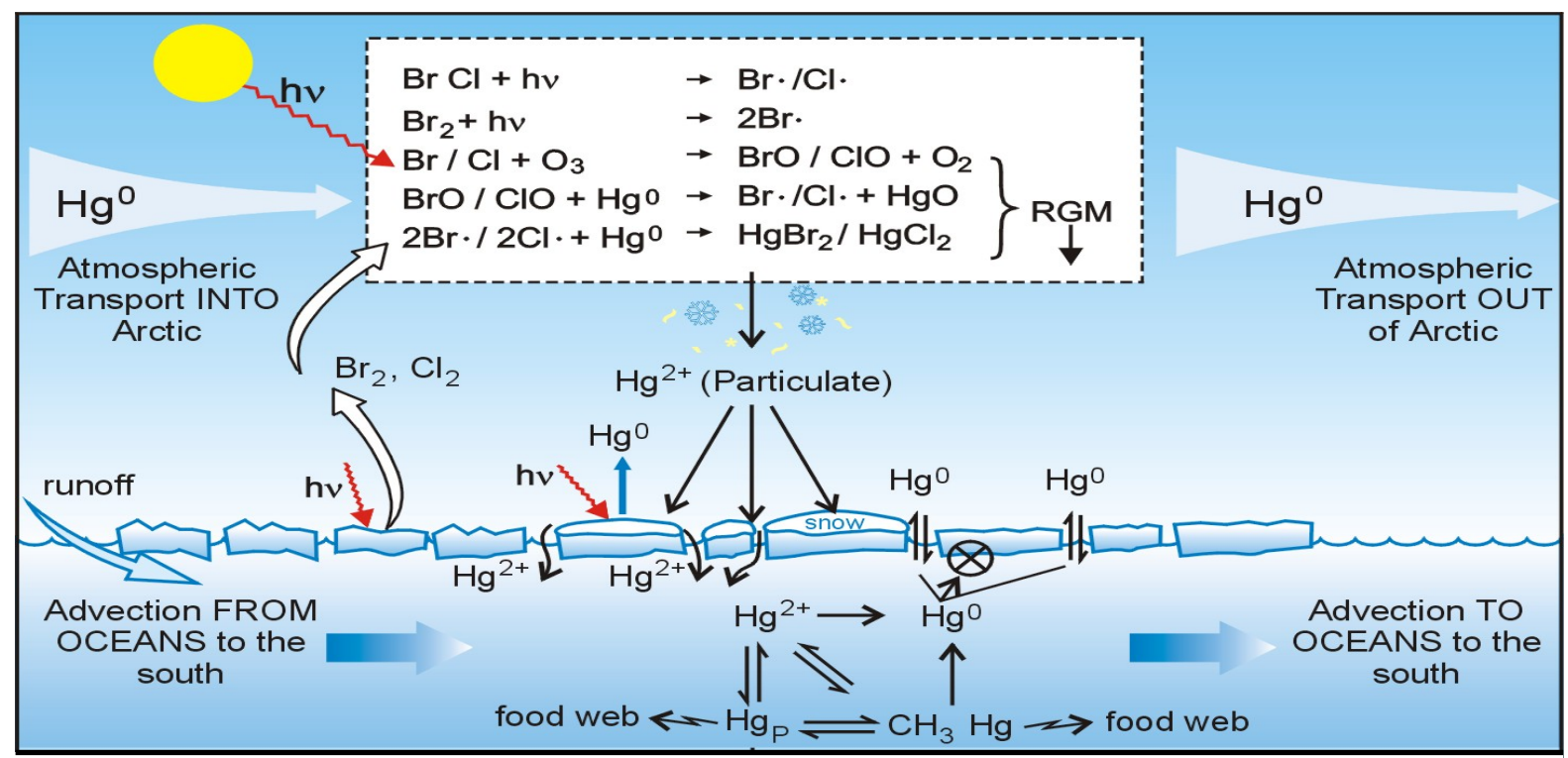

Fig. 3. Schematic of the cycling of mercury in Polar Regions (modified from MacDonald et al., 2005).

sunrise, GEM and ozone concentrations were found to deplete at the same time with excellent correlations during the period between late March and mid-June (correlation coefficient $\left[r^{2}\right]$ between GEM and $\mathrm{O}_{3}$ is $\left.\sim 0.8\right)$. This relationship between ozone and GEM appears endemic to other locations in Arctic Regions (Lindberg et al., 2001; Berg et al., 2003a; Skov et al., 2006) and the sub-arctic (Poissant and Pilote, 2003) ${ }^{1}$. Soon after the first publication of AMDEs (Schroeder et al., 1998), continuous highly time resolved measurements of total gaseous mercury (TGM) were also carried out at the German Antarctic research station Neumayer between January 2000 and February 2001 (Ebinghaus et al., 2002). These measurements corroborated the hypothesis that AMDEs do also occur in the Antarctic, giving evidence that both Polar Regions are impacted by an enhanced atmospheric $\mathrm{Hg}$ deposition during polar springtime.

At Alert in 1998, Lu et al. (2001) and Lu and Schroeder (2004) reported an anti-correlation between measured gas phase $\mathrm{Hg}$ and the concentration of $\mathrm{HgP}$ during AMDEs. They suggested that GEM was being converted to total particulate and reactive gas phase mercury (RGM) when AMDEs occurred. This hypothesis that RGM is produced during AMDEs was confirmed in 2000 through direct measurements by Lindberg et al. (2001) at Barrow, Alaska, USA. Steffen et al. (2002) measured TAM at Alert in 2000 and showed that during depletion events other forms of $\mathrm{Hg}$ species exist in the air besides GEM. This study also demonstrated that, during depletion events, on average only $50 \%$ of the converted GEM remains in the air during AMDEs. It was

\footnotetext{
${ }^{1}$ The geographic scope of the discussion in this section has been limited to Polar Regions (north and south of $60^{\circ}$ ) and does not include work conducted in sub-polar regions
}

proposed that the remainder of the converted $\mathrm{Hg}$ is deposited onto the nearby snow and ice surfaces. Figure 3 shows a summary schematic of the cycling of $\mathrm{Hg}$ resulting from AMDEs around Polar Regions.

\subsubsection{How and where do AMDEs occur?}

It is now thought that the chemistry that causes the well known ozone depletion events (ODEs) (Bottenheim et al., 1986; Barrie et al., 1988; Simpson et al., 2007) is similar to what drives AMDEs (Lindberg et al., 2001; Ariya et al., 2002b; Lindberg et al., 2002; Calvert and Lindberg, 2004b; Goodsite et al., 2004). The depletion of GEM in the polar atmosphere is thought to be caused by the oxidation of GEM by reactive halogens; namely $\mathrm{Br}$ atoms or $\mathrm{BrO}$ radicals (Ariya et al., 2004; Calvert and Lindberg, 2004a; Goodsite et al., 2004; Skov et al., 2004) (see Sect. 4.3 for more detail). The reaction (oxidation) of $\mathrm{Hg}(0)$ with this reactive halogen yields inorganic RGM, $\mathrm{Hg}$ (II). While there are mechanisms and theoretical calculations that suggest that RGM is predominantly a bromide compound (Calvert and Lindberg, 2004a), its identity has not been directly elucidated and thus RGM is operationally defined. The reactive halogen species oxidizing $\mathrm{Hg}$ are assumed to be generated from open water regions such as leads or polynyas from refreezing sea ice forming on open waters and UV radiation. High column densities of $\mathrm{BrO}$ clouds above areas of AMDEs have been seen in the air column by the GOME satellite throughout the Arctic and the Antarctic as shown in Fig. 4 (Lu et al., 2001; Ebinghaus et al., 2002; Lindberg et al., 2002; Wangberg et al., 2003; Sprovieri et al., 2005a). Bottenheim and Chan (2006) reported that ODEs observed at Arctic measurement 

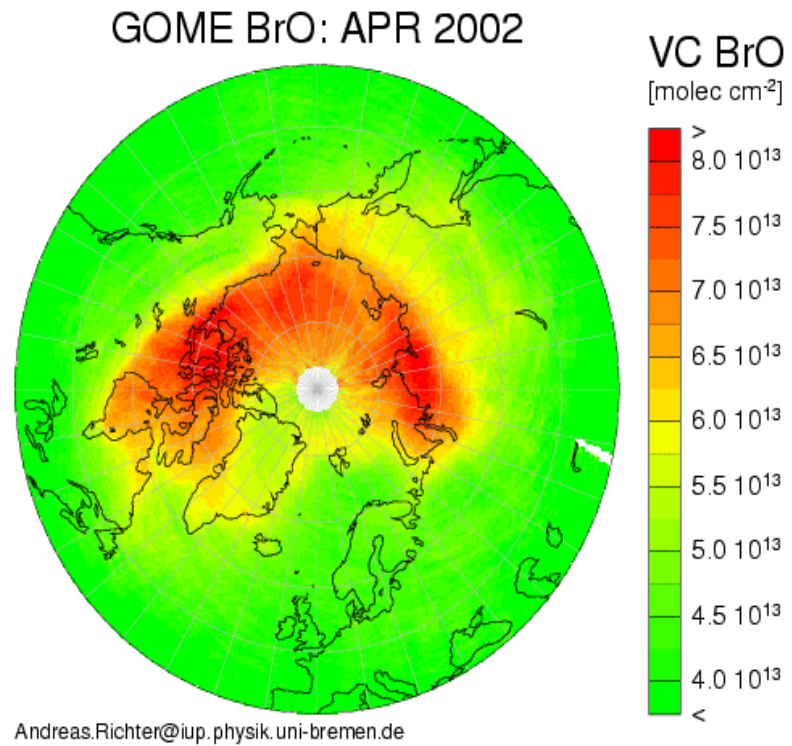

Andreas.Richter@iup. physik.uni-bremen.de

(a)

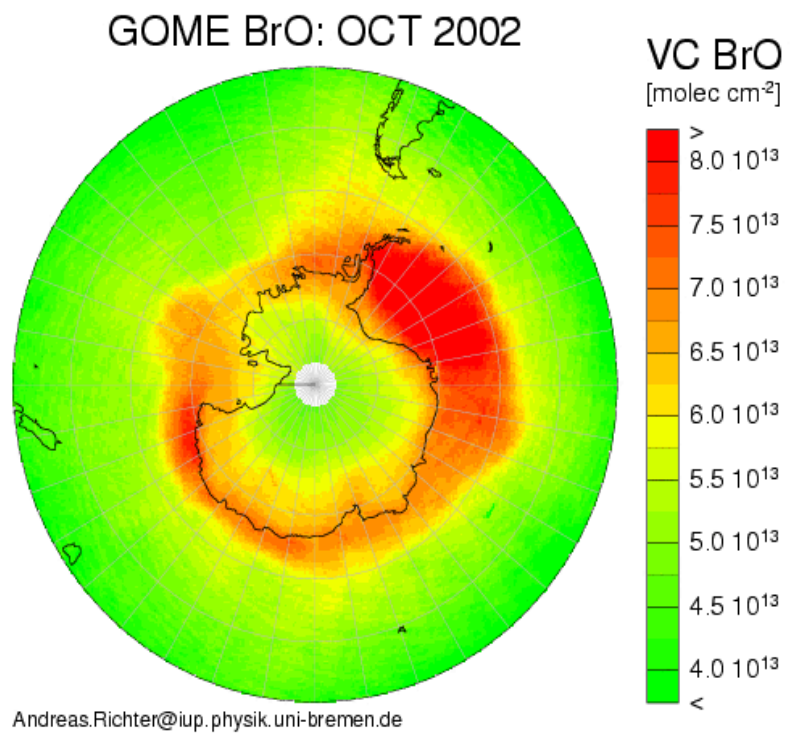

(b)

Fig. 4. GOME BrO measurements over (a) the Arctic April 2002 and (b) the Antarctic October 2002. The values given are in molecules $/ \mathrm{cm}^{2}$. Green areas correspond to low $\mathrm{BrO}$ concentration values and the red areas correspond to higher $\mathrm{BrO}$ concentration values.

sites originate over the Arctic Ocean near marginal ice zones where high concentrations of $\mathrm{BrO}$ are observed. In addition, in-situ measurements of $\mathrm{BrO}$ were made in Alert and showed that an increase in the $\mathrm{BrO}$ concentration is matched by a decrease in GEM (Steffen et al., 2003b). BrO was measured in the layer near the earth's surface at $1 \pm 0.5 \mathrm{~km}$ (Hönninger and Platt, 2002). This observation matches well with vertical profile measurements (Banic et al., 2003) that showed AMDEs are limited to the surface up to a maximum of $1 \mathrm{~km}$ and by Tackett et al. (2007), who showed that the most active halogen chemistry affecting $\mathrm{Hg}$ is within the first $100-200 \mathrm{~m}$ from the snow surface. Further experiments by Steffen et al. (2002) showed that depletion events occur immediately at the snow surface (less than $2 \mathrm{~m}$ ) and within the first few centimetres of the snow pack. Studies at the Ny-Ålesund station, where GEM levels were measured at two heights (12 m a.s.l and $474 \mathrm{~m}$ a.s.l) in the spring time during AMDEs, showed that GEM concentrations during AMDEs are comparable (Berg et al., 2003b; Temme et al., 2004; Sprovieri et al., 2005b; Sommar et al., 2007) but concentration differences between the two elevations were reported prior to AMDEs. In addition, at $12 \mathrm{~m}$ a.s.l., GEM concentrations following AMDEs were found to be higher in magnitude and displayed higher variability in comparison to results reported at $474 \mathrm{~m}$ a.s.l (Berg et al., 2003b; Sprovieri et al., 2005a; Sommar et al., 2007). These results imply that there is a cycling of mercury that occurs near the surface and the air masses are not well mixed within the boundary layer to be measured at heights of $474 \mathrm{~m}$ a.s.l.

\subsubsection{Mercury speciation and AMDEs}

Lindberg et al. $(2001,2002)$ reported the first and highest measured concentration levels of RGM (up to $900 \mathrm{pg} / \mathrm{m}^{3}$ ) during AMDEs at Barrow and showed a strong correlation between RGM production and UV-B irradiation. The increase of UV-B over the springtime period also correlated well with an increase in surface snow $\mathrm{Hg}$ concentrations. Similar observations were made in the Beaufort Sea on the SHEBA ship in 1997 (Lu et al., 2001). RGM (and PHg) have a higher deposition velocity (Skov et al., 2006) and is more hygroscopic (Lin and Pehkonen, 1999) than GEM (Lindberg et al., 2001; Cobos et al., 2002; Skov et al., 2004; Brooks et al., 2006) and thus are readily deposited onto the snow and ice surfaces.

Both RGM and PHg have been measured during AMDEs at many Arctic sites (Lindberg et al., 2002; Berg et al., 2003a; Steffen et al., 2003a; Aspmo et al., 2005; Gauchard et al., 2005; Sprovieri et al., 2005a). Mercury species measurements in the Antarctic have only been made during the Antarctic summer at Terra Nova Bay from November to December 2000 (Sprovieri et al., 2002) and at Neumayer Station between December 2000 and February 2001 (Temme et al., 2003). Maximum RGM concentrations (exceeding $300 \mathrm{pg} / \mathrm{m}^{3}$ ) were observed during the Antarctic summer and a process other than the halogen chemistry suggested above for the oxidation of GEM was proposed (Sprovieri et al., 2002).

The relative distribution of these two atmospheric species differs between locations. RGM can exist in the gas phase but will be readily sorbed onto aerosols present in the air because of its hygroscopic properties (Ariya et al., 2004). At Alert, the overall predominant species in spring is $\mathrm{PHg}$ (Steffen et al., 2003b) but a clear shift from the predominance of PHg to RGM is observed during the spring (Kirk et 
al., 2006; Cobbett et al., 2007). At Barrow, RGM is the predominant species observed (Lindberg et al., 2002). Several studies at Ny-Ålesund have shown that, in general, there is no predominance of either RGM or PHg (Gauchard et al., 2005; Sprovieri et al., 2005a, b). Some researchers have suggested that the distribution of the RGM and PHg is an indication of the age of an air mass (Lindberg et al., 2002; Steffen et al., 2003a; Sprovieri et al., 2005a) while others suggest that the distribution is an indication of local versus transported events (to the measurement site) (Wangberg et al., 2003; Gauchard et al., 2005). The presence of UV radiation is also thought to contribute to the distribution of RGM and $\mathrm{PHg}$ as suggested by Lindberg et al. (2002). During low levels of UV the RGM present in the air is sorbed onto aerosol bound $\mathrm{Br}$ and/or $\mathrm{Cl}$ but at higher levels of UV this aerosol is rapidly decomposed and RGM becomes the predominant species. This hypothesis was later used by Sprovieri et al. (2005a) and found the same results at $\mathrm{Ny}$-Ålesund in 2003.

\subsubsection{Mercury deposition to snow caused by AMDEs}

Studies have shown that the concentration of $\mathrm{Hg}$ in the snow increases during and following AMDEs where oxidized atmospheric $\mathrm{Hg}$ is thought to have been deposited (Lu et al., 2001; Lindberg et al., 2002; Steffen et al., 2002; Sommar et al., 2007). The fate of this deposited $\mathrm{Hg}$ is under debate in the scientific $\mathrm{Hg}$ community in terms of how much of this deposited $\mathrm{Hg}$ is emitted as GEM through photoreduction and how much remains in the snow (this is further discussed in Sect. 6, post deposition scenarios). Atmospheric profile measurements of GEM collected in 2000 (Steffen et al., 2002) showed that after AMDEs, some $\mathrm{Hg}$ was emitted from the snow surface. As the depletion event aloft continued, this emitted $\operatorname{Hg}(0)$ then appeared to be oxidized right at the snow surface. This data demonstrated a cycling of $\mathrm{Hg}$ that occurs immediately near the snow surface (and within the snow pack). This was attributed to a combination of snow/air temperature as well as solar radiation (Lu et al., 2001; Lindberg et al., 2002; Steffen et al., 2002).

In Barrow, Lindberg et al. (2002) measured concentrations of up to $90 \mathrm{ng} / \mathrm{L}$ in the snow, which is higher than the concentration of $\mathrm{Hg}$ found in snow from background regions. Also at Barrow, Scott (2001) reported a post polar sunrise increase in bioavailable $\mathrm{Hg}$ in the surface snow and an increasing ratio of bioavailable to $\mathrm{THg}$ as the springtime slowly progressed to annual snowmelt. In Svalbard, Ferrari et al. (2005) demonstrated that of seven AMDEs recorded, no increase in the concentration of $\mathrm{Hg}$ in the surface snow was observed. The authors suggest that the origin of the AMDE plays a significant role in the amount of $\mathrm{Hg}$ deposition that is observed. Thus, deposition of $\mathrm{Hg}$ onto the snow surfaces in the Arctic, as a result of AMDEs, are not spatially homogeneous and the factors affecting such deposition must be well understood to address the impacts of AMDEs on the Arctic environment.

\subsubsection{Mass Balance and the deposition of mercury}

To the date of this review, an annual mass balance does not exist for $\mathrm{Hg}$ in Polar Regions or at any specific measurement sites. Brooks et al. (2006) recently published a mass balance for $\mathrm{Hg}$ in the Arctic springtime showing a net surface gain during a 2 week period from data collected at Barrow, AK. However, there are many limitations associated with calculating such a mass balance that the applicability of their reported techniques cannot be applied to annual mass balances over the whole region. Such limitations include the lack of knowledge of $\mathrm{Hg}$ speciation in the atmosphere, the potential for inter-compartmental transfer of $\mathrm{Hg}$ in Polar Regions and the lack of a circumpolar network collecting $\mathrm{Hg}$ measurements. During a meeting of experts in 2003, the need to establish the emission proportion of $\mathrm{Hg}$ from the surface after deposition from AMDEs, or release to other compartments, was identified and must be agreed upon before true mass balance estimates could be made (Schroeder et al., 2003). Further, an experts meeting in 2006 (AICI) determined that despite intense trans-arctic springtime field campaigns this remains an issue to be resolved. Several lines of evidence, based on atmospheric measurements and models, have shown strong net deposition of $\mathrm{Hg}$ to Arctic areas as a result of AMDEs. Lu et al. (2001) estimated a total deposition of 50 tons year ${ }^{-1}$ over northern waters. Lindberg et al. (2002) estimated that between 100 and 300 tons of $\mathrm{Hg}$ will be deposited from the atmosphere in polar spring. Banic et al. (2003) estimated a total deposition resulting from AMDEs of 100 tons year ${ }^{-1}$ over areas north of $70^{\circ}$ (15 times the area of Lu et al.) Ariya et al. (2004) estimated that 225 tons year $^{-1}$ of $\mathrm{Hg}$ is deposited in the Arctic (and a portion of the sub-Arctic) without considering AMDEs and an additional 135 tons year ${ }^{-1}$ was estimated to be deposited as a result of AMDEs. Further analysis showed that the highest deposition of $\mathrm{Hg}$ was found in the European part of the Arctic while the lowest were over the Canadian Arctic and Greenland. Another model calculated an estimated load of 208 tons year $^{-1}$ of $\mathrm{Hg}$ to the Arctic (this model did not consider emission from the snow surface) (Skov et al., 2004). There have been no reported deposition estimates for the Antarctic. These depositional estimates should be carefully compared and reviewed with estimates provided by measurements made in environmental archives in the Arctic. For example, Hg concentration measurements and age dating of peat from the Canadian Arctic show that the natural "background" $\mathrm{Hg}$ accumulation rate is relatively constant (ca. 1 microgram per sq. $\mathrm{m}$ per yr.) throughout the past 6000 years (Givelet et al., 2004).

\subsection{Mechanisms of AMDEs}

It is important to understand the kinetics and thermodynamics of the elementary and complex reactions of GEM in the 
atmosphere to truly comprehend the chemical and physical transformation of $\mathrm{Hg}$ in Polar Regions. Several review articles have been published on the transformation of $\mathrm{Hg}$ in the atmosphere and have addressed the properties, sources, sinks and fluxes of $\mathrm{Hg}$ (Lindqvist and Rodhe, 1985; Schroeder et al., 1991; Lin and Pehkonen, 1999). However, following the discovery of AMDEs, the search for an explanation of how the conversion of $\mathrm{Hg}$ occurs in the Polar troposphere began. Because AMDEs follow the same pattern as ODEs (Schroeder et al., 1998), it was thought that the production of a reactive gas phase species of $\mathrm{Hg}$ may be attributed to the same photochemically initiated reaction mechanisms (Lu et al., 2001; Lindberg et al., 2002). Further, the reaction of $\mathrm{Hg}$ with halogen oxide radicals drew attention to satellite "BrO" column measurements that began to surface around that time (Richter et al., 1998; Müller et al., 2002; van Roozendael et al., 2002), see Fig. 4. Several publications have shown the coincidence of increased $\mathrm{BrO}$ concentration measured from satellites around areas of strong AMDE occurrences (Lu et al., 2001; Ebinghaus et al., 2002; Lindberg et al., 2002; Wangberg et al., 2003; Skov et al., 2004; Sprovieri et al., 2005a; Brooks et al., 2006). Calvert and Lindberg (2004a) modeled the homogeneous component of halogen-mercury-ozone-chemistry and found that $\mathrm{Br}-\mathrm{BrO}$ can explain the observed processes occurring in the Polar springtime atmosphere. They also suggested that products such as $\mathrm{HgO}, \mathrm{HgBr}_{2}, \mathrm{BrHgOBr}$ and $\mathrm{BrOHgOBr}$ should be considered as potential components of RGM and PHg produced during AMDEs. In a companion paper, Calvert and Lindberg (2004b) investigated the influence of iodine on the chemistry of AMDEs. They confirmed their earlier conclusions in regard to the role of $\mathrm{Br}$ and concluded that depletions of $\mathrm{Hg}$ can be enhanced by the presence of photochemically active iodine compounds. Goodsite et al. (2004) proposed a homogeneous mechanism for $\mathrm{Hg}-\mathrm{Br}$ chemistry in the troposphere based on theoretical kinetic calculations and showed that gas phase oxidation of GEM by $\mathrm{Br}$ atoms could explain AMDEs in the Arctic springtime boundary layer. Brooks et al. (2006) report direct evidence of a link between $\mathrm{Br}$ and $\mathrm{Hg}$ chemistry as a direct source for RGM in Alaska. Holmes et al. (2006) conclude that uncertainties in the kinetic data, especially for reactions involving $\mathrm{HgBr}$ as a reactant, need to be resolved in order to more narrowly constrain the lifetime of $\mathrm{Hg}(0)$ and the $\mathrm{Hg}(\mathrm{II})$ product distribution.

The studies described above do not represent experimental research but rather models of mechanisms between $\mathrm{Hg}$ and halogens. There are few experimental studies that have reported reactions between halogens and halogen oxides with mercury. The limited number of experiments is primarily due to the complexity of these reactions and their side reactions. Recent studies by Ariya et al. (2002a) show extensive kinetic and product analysis on the reactions of GEM with molecular and atomic halogens $\left(\mathrm{X} / \mathrm{X}_{2}\right.$ where $\left.\mathrm{X}=\mathrm{Cl}, \mathrm{Br}\right)$ and the results from these and others are summarized in Table 4 (Donohoue et al., 2005; Sumner, 2005; Donohoue et al., 2006). These different experiments report more than an order of magnitude difference in reaction rates of $\mathrm{Br}$ and $\mathrm{Cl}$ with elemental mercury. While each technique has advantages and disadvantages it is recommended that future studies are targeted to these reactions and that an intercomparison between experimental studies be made to provide more information on reaction kinetics.

As discussed above, $\mathrm{BrO}$ is thought to be a key player in the oxidation of GEM during AMDEs yet experimental studies of such XO reactions are very scarce and, to the best knowledge of the authors, there has been only one published laboratory kinetic study on the reaction of $\mathrm{BrO}$ with elemental mercury (Raofie and Ariya, 2003). Calculated reaction rates from this study are reported as a bimolecular rate constant for $\mathrm{BrO}+\mathrm{Hg}(0)_{(\mathrm{g})}$ and are shown in Table 4. The estimated value implies that $\mathrm{BrO}$ is a significant potential contributor to AMDEs reported in Polar Regions. Raofie and Ariya (2004) published the first experimental product study of $\mathrm{BrO}$ initiated oxidation of GEM where the reaction products were analysed in the gas phase, on suspended aerosols and on wall deposits. In this study, the products were identified to be $\mathrm{HgBr}, \mathrm{HgOBr}$ or $\mathrm{HgBrO}$ and $\mathrm{HgO}$. The existence of a stable $\mathrm{Hg}(\mathrm{I})$, in the form of $\mathrm{HgBr}$ and $\mathrm{Hg}(\mathrm{II})$, upon a BrO-initiated oxidation of $\mathrm{Hg}(0)$, emphasizes the importance to selectively quantify various mercury species in aerosols and deposits in field studies. While most of the products containing mercury were identified as deposits, aerosols did account for a substantial portion of products.

Existing kinetic results indicate that the direct $\mathrm{Br}$ reaction with GEM is more important than BrO (Raofie and Ariya, 2003; Goodsite et al., 2004). While modeling studies (Ariya et al., 2004; Skov et al., 2004) support this conclusion further studies are required to examine the GEM and $\mathrm{Br}$ reaction in order to explain elemental $\mathrm{Hg}$ depletion in Polar Regions. While Calvert and Lindberg (2004a, b) suggest the importance of iodine in AMDEs, there exist no laboratory studies on the kinetics and products of $\mathrm{I}_{2}, \mathrm{I}$ and IO with GEM. The authors encourage additional studies in this domain to expand our understanding of tropospheric iodine chemistry further.

Despite the recent positive trend in the number of laboratory and theoretical studies of gas-phase elemental $\mathrm{Hg}$, focused kinetic, thermo-chemical and mechanistic studies of $\mathrm{Hg}(0)$ are still relatively scarce and somewhat inconsistent. These studies are needed in order to further our understanding of the atmospheric chemistry of $\mathrm{Hg}$ during the polar spring. It is pivotal to provide kinetic, product and thermochemical studies on complex reactions. A detailed review of ab-initio thermochemical and kinetic studies of $\mathrm{Hg}$ reactions has been reported by Ariya and Peterson (2005) and details of the methods and values important for this review are discussed in more detail in other publications (Balabanov et al., 2005; Shepler et al., 2005). Finally, experimental studies on the uptake and kinetics of heterogeneous reactions of $\mathrm{Hg}$ on various environmentally relevant surfaces such as ice, snow, 
Table 4. Available literature of rate constants for selected atmospheric mercury reactions (at room Temperature (296+/-2 K)).

\begin{tabular}{|c|c|c|c|}
\hline Reaction & $\begin{array}{l}\text { Rate constants } \\
\left(\text { molecule } / \mathrm{cm}^{3} \mathrm{~s}^{1}\right)\end{array}$ & Reference & Comments \\
\hline \multirow[t]{3}{*}{$\mathrm{Hg}^{0}+\mathrm{O}_{3} \rightarrow$ products } & $(3 \pm 2) \times 10^{-20}$ & (Hall, 1995) & \\
\hline & $(7.5 \pm 0.9) \times 10^{-19}$ & (Pal and Ariya, 2004) & Temperature dependence is evaluated \\
\hline & $(6.4 \pm 2.3) \times 10^{-19}$ & (Sumner, 2005) & \\
\hline \multirow[t]{3}{*}{$\mathrm{Hg}^{0}+\mathrm{HO} \rightarrow$ products } & $(8.7 \pm 2.8) \times 10^{-14}$ & (Sommar et al., 2001) & \\
\hline & $(9.3 \pm 1.3) \times 10^{-14}$ & (Pal and Ariya, 2004) & $\begin{array}{l}\text { Temperature dependence is evaluated } \\
\text { at } 100 \text { and } 400 \text { Torr He and air }\end{array}$ \\
\hline & $<10^{-13}$ & (Bauer et al., 2003) & \\
\hline \multirow[t]{4}{*}{$\mathrm{Hg}^{0}+\mathrm{Cl} \rightarrow$ products } & $(1.0 \pm 0.2) \times 10^{-11}$ & (Ariya et al., 2002b) & \\
\hline & $(1.5) \times 10^{-11}$ & (Horne et al., 1968) & $120-170^{\circ} \mathrm{C}$ \\
\hline & $2.8 \times 10^{-11}$ & (Khalizov et al., 2003) & Theoretical \\
\hline & $7.6 \times 10^{-13}$ & (Donohoue et al., 2005) & $\begin{array}{l}\text { Second-order rate was calculated at } \\
260 \mathrm{~K} \text { and } 760 \text { Torr }\end{array}$ \\
\hline \multirow{2}{*}{$\mathrm{Hg}^{0}+\mathrm{Cl}_{2} \rightarrow$ products } & $(2.7 \pm 0.2) \times 10^{-18}$ & (Ariya et al., 2002a) & \\
\hline & $(2.5 \pm 0.9) \times 10^{-18}$ & (Sumner, 2005) & \\
\hline \multirow[t]{5}{*}{$\mathrm{Hg}^{0}+\mathrm{Br} \rightarrow$ products } & $(3.2 \pm 0.3) \times 10^{-12}$ & (Ariya et al., 2002a) & \\
\hline & $(2.7) \times 10^{-13}$ & (Grieg et al., 1970) & $120-170^{\circ} \mathrm{C}$ \\
\hline & $2.0 \times 10^{-12}$ & (Khalizov et al., 2003) & $\begin{array}{l}\text { Theoretical - calculated at } 298 \mathrm{~K} \text {, } \\
760 \text { Torr }\end{array}$ \\
\hline & $1.1 \times 10^{-12}$ & (Goodsite et al., 2004) & $\begin{array}{l}\text { Theoretical - calculated at } 298 \mathrm{~K} \text {, } \\
760 \text { Torr }\end{array}$ \\
\hline & $3.6 \times 10^{-13}$ & (Donohoue et al., 2006) & \\
\hline \multirow[t]{2}{*}{$\mathrm{Hg}^{0}+\mathrm{BrO} \rightarrow$ products } & $1 \times 10^{-15}<\mathrm{k}<1 \times 10^{-13}$ & (Raofie and Ariya, 2003) & \\
\hline & $1 \times 10^{-14}$ & (Sumner, 2005) & \\
\hline \multirow[t]{2}{*}{$\mathrm{Hg}^{0}+\mathrm{Br}_{2} \rightarrow$ products } & $\leq(9 \pm 2) \times 10^{-17}$ & (Ariya et al., 2002a) & \\
\hline & No reaction & (Sumner, 2005) & $\begin{array}{l}\text { No reaction was observed under exper- } \\
\text { imental conditions employed }\end{array}$ \\
\hline $\mathrm{Hg}^{0}+\mathrm{F}_{2} \rightarrow$ products & $(1.8 \pm 0.4) \times 10^{-15}$ & (Sumner, 2005) & \\
\hline $\mathrm{Hg}^{0}+\mathrm{NO}_{3} \rightarrow$ products & $\leq 4 \times 10^{-15} \leq 7 \times 10^{-15}$ & $\begin{array}{l}\text { (Sommar et al., 1997; } \\
\text { Sumner, 2005) }\end{array}$ & \\
\hline $\mathrm{Hg}^{0}+\mathrm{H}_{2} \mathrm{O}_{2} \rightarrow$ products & $\leq 8 \times 10^{-19}$ & (Tokos et al., 1998) & \\
\hline $\mathrm{Hg}\left(\mathrm{CH}_{3}\right)_{2}+\mathrm{HO} \rightarrow$ products & $(1.97 \pm 0.23) \times 10^{-11}$ & (Niki et al., 1983b) & \\
\hline $\mathrm{Hg}\left(\mathrm{CH}_{3}\right)_{2}+\mathrm{Cl} \rightarrow$ products & $(2.75 \pm 0.3) \times 10^{-10}$ & (Niki et al., 1983a) & \\
\hline $\mathrm{Hg}\left(\mathrm{CH}_{3}\right)_{2}+\mathrm{NO}_{3} \rightarrow$ products & $(7.4 \pm 2.6) \times 10^{-14}$ & (Sommar et al., 1996) & \\
\hline
\end{tabular}

and aerosols are, as of yet, unexplored domains that should be undertaken in future research.

\subsection{Transects of mercury away from the edge of the ocean}

As discussed above, it is assumed that sea ice is a necessary ingredient in the recipe for producing AMDEs as sea ice is a source of the reactive halogens required to facilitate AMDE reactions (Richter et al., 1998; Wagner and Platt, 1998; Lindberg et al., 2002; Ariya et al., 2004; Frieß et al., 2004; Simpson et al., 2007). As well, the snow pack may be both a source and a sink for reactive halogens thereby providing a wide spatial region over which reactive halogen chemistry can occur (Simpson et al., 2005). Further evidence linking sea ice with AMDEs is that they are not reported at lower latitudes and they are only reported in regions near the coast (Lu et al., 2001; Garbarino et al., 2002) or within 200 kilometers of sea ice (Snyder-Conn et al., 1997; Lu et al., 2001; Douglas and Sturm, 2004). Along the northern Canadian coast, Lu et al. (2001) reported the highest mercury concentrations in snow were collected between 70 and $75^{\circ} \mathrm{N}$ with lower concentrations around Hudson's Bay (55 to $65^{\circ} \mathrm{N}$ ). Their results also show that snow collected near open sea ice regions yields greater $\mathrm{Hg}$ deposition rates. Investigations of $\mathrm{Hg}$ in coastal and inland snow in the Alaskan Arctic (Snyder-Conn et al., 1997; Garbarino et al., 2002) provide further information suggesting that the highest $\mathrm{Hg}$ concentrations in the Arctic are found in coastal snow. These studies 


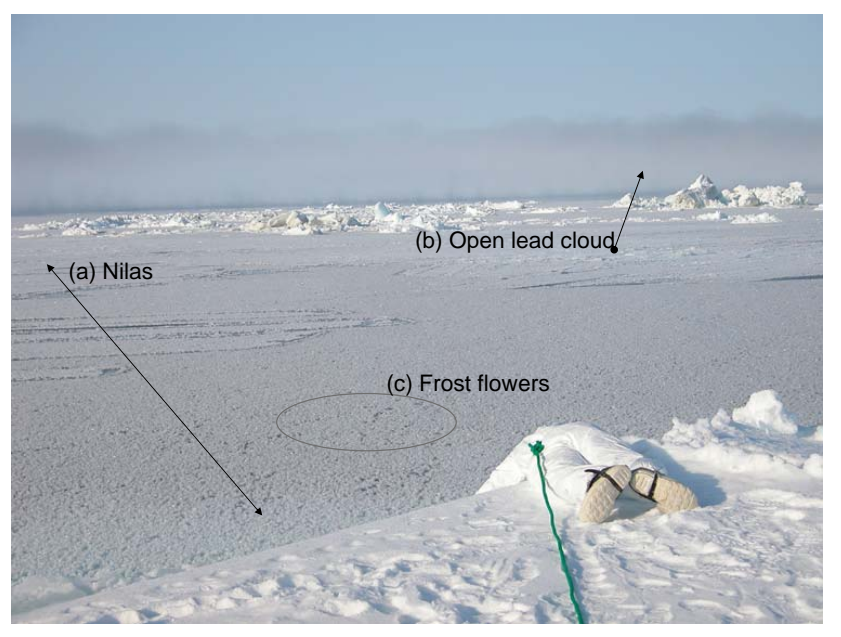

Fig. 5. Photo describing ice features from a location on the ice near Barrow, Alaska during the Arctic spring where samples have been collected for mercury. Shown in this photo are (a) nilas (new sea ice); (b) an open lead - evident by the gray cloud and (c) a newly formed frost flower field.

used cores of the entire snow pack collected in May that represent a full year of snow accumulation. Thus, AMDE deposition active in the March to May timeframe is likely diluted by pre-AMDE snow with a low $\mathrm{Hg}$ concentration (approximately $5-8 \mathrm{ng} / \mathrm{L}$ or lower). Elevated $\mathrm{Hg}$ concentrations were measured in coastal snow cores from three out of the four transect reported. Snow cores collected on sea ice yielded far greater $\mathrm{Hg}$ concentrations (100-214 ng/L) than those collected at coastal $(3-83 \mathrm{n} / \mathrm{L})$ or inland $(0.1-7.2 \mathrm{ng} / \mathrm{L})$ locations. This may partially be attributed to a smaller fraction of the low concentration pre-AMDE snow pack being represented in the sea ice cores. Since the sea ice develops in December or January any snow that fell earlier in the winter would not be preserved in the snow pack on the sea ice. Snow on sea ice generally contains a higher halogen ion content than terrestrial snow (Simpson et al., 2005). Snow on sea ice generally contains a higher halogen ion content than terrestrial snow (Simpson et al., 2005) and this may promote AMDE chemistry on sea ice but this hypothesis has never been tested. More work needs to be done to address the differences in AMDE $\mathrm{Hg}$ deposition to snow on sea ice or land as these two ecosystems may promote different processes in the polar biochemical cycle of $\mathrm{Hg}$.

The snow collection sites were all more than $75 \mathrm{~km}$ from the coast and yielded total $\mathrm{Hg}$ concentrations ranging between 0.5 and $2 \mathrm{ng} / \mathrm{L}$. The concentration of $\mathrm{Hg}$ from the site closest to the Arctic Ocean coast $(75 \mathrm{~km})$ increased from 3 to $6 \mathrm{ng} / \mathrm{L}$ between pre- and post- AMDE conditions. Typical $\mathrm{Hg}$ concentrations in surface snow collected along the Arctic Ocean Coast near Barrow during an AMDE range between 12 and $100 \mathrm{ng} / \mathrm{L}$ (Lindberg et al., 2002; Douglas et al., 2005). The lower values further inland indicate that snow located near the coast receives the greatest AMDE Hg signature while inland snow receives minimal AMDE Hg deposition. A similar study was conducted in the sub-Arctic on the shore of Hudson's Bay that showed $\mathrm{Hg}$ concentrations in the snow increased after AMDEs and was inversely proportional to distance from the bay (Constant et al., 2007).

\subsection{The role of sea ice in AMDE chemistry}

Sea ice leads and polynyas provide a unique link between warm sea water and the cold overlying Arctic air. In Polar Regions during late winter and spring ambient air is typically colder than seawater and this creates convection cells in the lower atmosphere above exposed ocean water (Alam and Curry, 1995; Muench et al., 1995; Pinto and Curry, 1995; Pinto et al., 1995). These convection cells transfer heat from exposed ocean water to the lower $1 \mathrm{~km}$ of the atmosphere (Pinto and Curry, 1995; Pinto et al., 1995). A dark grey cloud of saturated moisture commonly forms above open water regions (Fig. 5 of sea ice lead). Water vapour density measured in the boundary layer above sea ice in the Arctic and Antarctic is almost always near ice saturation due to the exposure of warm sea water in leads and polynyas (Andreas et al., 2002) and thus crystals that form near sea ice and leads are commonly formed from the vapour phase. Diamond dust (ice crystal precipitation that falls under cold clear skies below $-20^{\circ} \mathrm{C}$ (Girard and Blanchet, 2001)) and surface hoar (faceted, feather shaped clusters of ice that grow when the near surface relative humidity is at saturation with respect to ice (Andreas et al., 2002)) are commonly observed near sea ice leads. Thus, sea ice provides a location where enhanced crystallization and scavenging of moisture from the vapour phase may occur.

Douglas et al. (2005), collected surface hoar crystals formed near leads that yielded $\mathrm{Hg}$ concentrations up to $820 \mathrm{ng} / \mathrm{L}$. These values are greater than previously reported maximum values for snow collected following AMDEs that typically range between 80 and $100 \mathrm{ng} / \mathrm{L}$ (Lu et al., 2001; Lindberg et al., 2002). Douglas et al. (2005) proposed two hypotheses to explain the reported high $\mathrm{Hg}$ concentrations near leads: 1) convective processes promoted halogen transfer to the air above the leads and this led to enhanced AMDE chemistry, and/or 2) the convection process and supersaturated air above the lead promoted enhanced active growth of snow and ice crystals from the vapour phase that readily scavenged available RGM. Results from a recent study investigating mercury deposition to a range of snow and ice crystal types (Douglas et al., 2008) suggest that enhanced scavenging of $\mathrm{Hg}$ by condensing ice crystals is the most likely source of elevated $\mathrm{Hg}$ near leads. Ice crystals grown from the vapor phase like surface hoar (up to $975 \mathrm{ng} / \mathrm{L}$ ) and diamond dust (92 to $1370 \mathrm{ng} / \mathrm{L}$ ) yield the highest mercury concentrations reported to date. Frost flowers are formed from a combination of brine and vapor condensation and they yield mercury concentrations ranging from 140 to $180 \mathrm{ng} / \mathrm{L}$ (Douglas 
et al., 2008). More work needs to be done to investigate how unique crystal forms may scavenge $\mathrm{Hg}$ differently but, of most importance, is a better understanding of the ultimate fate of $\mathrm{Hg}$ scavenged by snow and ice crystals following spring melt. Stable mercury isotopes provide a potentially promising tool to track $\mathrm{Hg}$ from deposition to melt and into ecosystem pools.

The sea ice environment is also enhanced in halogen concentration from the fractionation of halogen rich brines to the sea ice surface during ice growth. Halogen concentrations are elevated in snow on sea ice (Simpson et al., 2005; Simpson et al., 2007) and this may lead to enhanced AMDE chemistry near sea ice. Frost flowers on newly formed brine rich sea ice have been suggested as a potential source of halogens to initiate depletion chemistry in the sea ice lead environment (Rankin et al., 2002; Kaleschke, 2004; Jacobi et al., 2006) because these delicate crystals commonly form on young ice growing on refreezing sea ice leads and are enhanced in halogens (approximately 3 times higher than seawater). However, frost flowers grow in regions that once included open water and contained nilas (new ice) that promotes the fractionation of salty brine upward to the ice surface. In addition, the snow pack on sea ice and land may be both a source and a sink for reactive halogens (Simpson et al., 2005) or a location where active halogen chemistry could occur. The snow pack covers a greater surface area than frost flower fields and is not dependent on sea ice processes and, therefore, may have a greater spatial and temporal impact on the extent of atmospheric chemistry relating to AMDEs. Further evidence linking sea ice with elevated $\mathrm{Hg}$ concentrations in nearby ecosystems is provided by a recent study in Antarctica where soils, lichens and mosses down wind of an open water polynya in Antarctica have yielded higher $\mathrm{Hg}$ concentrations than were at control sites far from the polynya (Bargagli et al., 2005). These results suggest that the processes driving elevated $\mathrm{Hg}$ deposition near open water regions of sea ice may affect nearby ecosystems.

Taken in total, it is apparent that sea ice plays a major role in AMDEs. Mercury concentrations in snow on sea ice are elevated compared to terrestrial snow nearby. Further, sea ice leads provide a unique location where vapour phase crystals may scavenge $\mathrm{Hg}$ at greater rates than typical snow precipitation. Though brine rich sea ice, snow and frost flower crystals are likely implicated in AMDE processes near leads their relative contribution to AMDE physical and chemical processes is largely unknown. A greater understanding of: 1) the role sea ice plays in $\mathrm{Hg}$ scavenging; 2) the connection between halogens on sea ice and $\mathrm{Hg}$ and 3) the relationship between snow and ice crystal formation processes and $\mathrm{Hg}$ scavenging must be achieved.

The discovery of AMDEs has altered our understanding of how $\mathrm{Hg}$ processes occur in Polar Regions. Because of this unique atmospheric transformation of $\mathrm{Hg}$, we have been forced to consider the changes in the physical pathways by which $\mathrm{Hg}$ transfers from the atmosphere to the rest of the ecosystem. The atmosphere is the first medium in which pollutants are found and this section has described the work undertaken to understand the mechanisms and processes of how $\mathrm{Hg}$ transforms in this medium.

\section{Modeling of mercury into and within the Arctic re- gion}

Due to the lack of long term spatial and temporal measurements of $\mathrm{Hg}$ in Arctic regions there is a reliance on modeling to estimate $\mathrm{Hg}$ loading rates. Further, modeling the response of deposition processes to changing $\mathrm{Hg}$ fluxes from different source regions has become increasingly relevant as North American emissions decrease while Eurasian industrial sources increase. Modeling can help see into the future as the changing source regions are combined with climate warming to challenge our predictive capabilities for assessing future deposition and storage regimes.

\subsection{Modeling of the transport of mercury to the Arctic}

Mercury is transported into the Arctic from global natural sources which include emission from oceanic, continental and previously deposited $\mathrm{Hg}$ sources and from current anthropogenic sources. Transport pathways of $\mathrm{Hg}$ to the Arctic are influenced by atmospheric circulation patterns on time scales ranging from a day to millennia (Raatz, 1984; Mayewski et al., 1997). The most prominent circulation patterns affecting the transport of $\mathrm{Hg}$ to the Arctic are the Pacific North America (PNA) and the North Atlantic Oscillations (NAO) (Wallace and Gutzler, 1981; Barnston and Livezey, 1987; Macdonald et al., 2005). Mid-latitude atmospheric blocking (Iversen and Joranger, 1985) also plays a major role in the transportation of pollutants to the Artic. Modeling shows a strong influence of NAO on pollution transport into the Arctic, particularly in the winter and spring seasons (Eckhardt et al., 2003). Mid-latitude blocking at the scale of 5-15 days is associated with elevated levels of Arctic inflow (Raatz, 1984) and is most frequent during the winter and spring seasons.

Transportation pathways of $\mathrm{Hg}$ to Alert, Nunavut have been modeled (Cheng and Schroeder, 2000). This model suggests possible source regions include Eastern Europe, the Northeast Coast of North America and central Siberia. A more recent model by Travnikov (Travnikov, 2005) examined the contribution of Northern hemispheric $\mathrm{Hg}$ emissions to the $\mathrm{Hg}$ deposition in the Arctic and reported the following distribution of $\mathrm{Hg}$ source regions: $24 \%$ from global oceanic sources, $33 \%$ from Asia, $22 \%$ from Europe, $10 \%$ from North America, $4 \%$ from Africa and 7\% from the Southern Hemisphere. This study concluded approximately half of the $\mathrm{Hg}$ deposited in the Arctic is from recent anthropogenic sources where Asia and Europe are the largest contributors. Further, a comprehensive GRAHM model developed by Dastoor and 
Larocque (2004) examined source regions of $\mathrm{Hg}$ to the Arctic and also highlighted the seasonal distribution of $\mathrm{Hg}$ in the Arctic. Dastoor and Larocque (2004) showed frequent episodes of $\mathrm{Hg}$ transport from Eurasian sources to the Arctic in winter due to the location of these sources northward of the Polar front. In addition, they also found trans-Pacific transport of $\mathrm{Hg}$ from East Asian sources in spring (predominantly) and in winter entering the Arctic. In contrast, during the summer, Dastoor and Larocque (2004) demonstrated that weak airflow movements and a confined polar front (north of $70^{\circ}$ ) prevent significant advection of $\mathrm{Hg}$ from mid-latitude regions to the Arctic. The main transport pathway of $\mathrm{Hg}$ to the Arctic during the spring and summer occurs through the ascent of air masses close to source regions, mediated by cyclones, followed by high-altitude transport and then a slow descent of the air mass into the Arctic, due to radiative cooling (Stohl, 2006). Finally, Jaffe et al. (2005) showed that long-range transport episodes of $\mathrm{Hg}$ from Asia to the North Pacific and North America are observed to be most frequent during the spring. This last finding is especially important to note when attempting to understand the role that spring time AMDEs play in $\mathrm{Hg}$ pollution in the Arctic environment.

\subsection{Modeling of atmospheric processes of mercury in the Arctic}

Chemical processes of $\mathrm{Hg}$ necessary for representation in atmospheric Hg models for Polar Regions include ambient gas phase chemistry, aqueous phase chemistry and chemistry on snow and ice surfaces. The necessary physical processes addressed by these models include dry deposition onto the ice and snow, aqueous phase deposition and $\mathrm{Hg}$ scavenging by cloud ice particles and snowfall.

Currently, there are two hemispheric $\mathrm{Hg}$ models including the Danish Eulerian Hemispheric Model (DEHM) (Christensen et al., 2004) and the Meteorological Synthesizing Centre-East hemispheric mercury model (MSCE-Hg-Hem) (Travnikov and Ryaboshapko, 2002) and one global Hg model: Global/Regional Atmospheric Heavy Metals Model (GRAHM) (Dastoor and Larocque, 2004) to represent Arctic mercury processes. GEM, RGM and PHg are the three $\mathrm{Hg}$ species simulated by these models. All models include current anthropogenic sources of Hg. MSCE-Hg-Hem and GRAHM also include oceanic and land based natural (including re-emission of previously deposited mercury) sources of $\mathrm{Hg}$.

In addition to the representation of free tropospheric $\mathrm{Hg}$ chemistry, these models reply on a simplified parameterization of the AMDE related Arctic boundary layer chemistry in the springtime due to the lack of sufficient knowledge of these chemical reactions. There are several differences between these 3 models and each model exhibits some shortcomings to truly representing the behaviour of AMDEs in Polar Regions. Christensen et al. (2004) in the DEHM included a linear fast oxidation of GEM by ozone in the boundary layer over sea ice during sunny conditions during Polar Sunrise. Although, the main features of AMDEs were reproduced by this model, it was not able to represent the high $\mathrm{Hg}$ concentrations in air following the depletion events or in the summertime. GRAHM included halogen oxidation processes of $\mathrm{Hg}$ based on the experimentally determined reaction rates (Ariya et al., 2002b) in the presence of sea ice. The Travnikov and Ryaboshapko MSCE-Hg-Hem model (Travnikov, 2005) included the GEM oxidation during AMDEs in the coastal regions during sunlight by converting GEM to RGM and PHg within the lowest $1 \mathrm{~km}$ near the surface. The models have been compared in Europe in a model intercomparison (Ryaboshapko et al., 2007). There is no direct comparison available in the Arctic region but the published independent studies on these models show (Ariya et al., 2004; Christensen et al., 2004; Travnikov, 2005) that they all capture the springtime depletion to some degree but fail to simulate the above average mercury concentrations observed following the AMDEs at some sites.

Dry deposition of GEM over ice and snow is neglected in the $\mathrm{Hg}$ models due to its low solubility characteristic (Lin and Pehkonen, 1999). The dry deposition of RGM and PHg is calculated by estimating the deposition velocities based on the resistance method capable of reproducing diurnal and seasonal variations (Wesely, 1989; Wang and Pehkonen, 2004). Deposition velocity in the resistance scheme is defined as the inverse of total resistance, where total resistance consists of the sum of aerodynamic resistance, quasi-laminar sub layer resistance and surface resistance. RGM surface resistance characteristics are assumed to be similar to that of nitric acid because of their similar solubility (Petersen et al., 1995). The dry deposition velocity for $\mathrm{PHg}$ is also a function of particle size and density.

Mercury deposition as RGM and PHg to the water is included in all the models. The oceanic emission of $\mathrm{Hg}(0)$ is also included in the models which depends on the surface temperature and the distribution of primary production activity in the oceans. The scavenging of soluble forms of $\mathrm{Hg}$ (RGM and PHg) by in-cloud ice and below-cloud snow is defined using scavenging coefficients similar to the scavenging coefficients for nitric acid (Petersen et al., 1995) in GRAHM and MSCE-Hg-Hem and similar to sulphate in DEHM (Christensen et al., 2004). Currently, Hg models do not include heterogeneous chemistry on the surface of snow and ice due to the lack of laboratory data required to generate accurate models. GRAHM and MSCE-Hg-Hem also consider the evaporation of precipitation which releases $\mathrm{Hg}$ to the atmosphere below the clouds.

In GRAHM, re-emission of $\mathrm{Hg}$ from snow and ice in the Arctic is treated as GEM as a fraction of the annual deposition of $\mathrm{Hg}$ in the Arctic (Ariya et al., 2004). However, the dynamic linkage between the $\mathrm{Hg}$ deposition during MDEs, photo-reduction of mercury in the snow pack or re-emission were not represented in the model due to the lack of thorough understanding of these processes. Re-emission from snow 
and ice is neglected in the other two models (Travnikov and Ryaboshapko, 2002; Christensen et al., 2004) as well. This is considered a large gap in information and future modeling efforts should focus on incorporating re-emission of $\mathrm{Hg}$ from snow and ice. All models estimated an upper limit of the contribution of $\mathrm{Hg}$ deposition by AMDEs and were unable to determine the true net accumulation of $\mathrm{Hg}$ to the Arctic because of the lack of adequate representation of $\mathrm{Hg}$ re-emission from snow and ice surfaces.

While models play a crucial role in understanding the present and predicting the future transport of $\mathrm{Hg}$ to the Arctic, their current limitations lie with our knowledge gaps about $\mathrm{Hg}$ processes in this region. Future modeling efforts should focus on ensuring deposition and re-emission of $\mathrm{Hg}$ from surfaces is incorporated within the models. The following section addresses the current state of knowledge about what happens to the $\mathrm{Hg}$ that is deposited to the environmental surfaces during AMDEs.

\section{Post-deposition scenarios}

6.1 Mercury deposition and re-emission to and from the snow

\subsubsection{Flux studies}

Since the first observations of AMDEs (Schroeder et al., 1998) there has been a large amount of interest in determining the air-surface exchanges (fluxes) of $\mathrm{Hg}$ species to better understand the springtime cycling of $\mathrm{Hg}$ in Polar Regions. In the high Arctic, the focus has mainly been on dry deposition of $\mathrm{Hg}$ because the climate is generally dry with little annual precipitation. Fluxes of $\mathrm{Hg}$ have been inferred from micrometeorology and chamber methods (See Sect. 3.2). The exchange of $\mathrm{Hg}$ between the air and snow pack associated with AMDEs are bi-directional and are dominated by RGM deposition resulting from the rapid in-situ oxidation of GEM. At Barrow, the MBR and REA micrometeorological methods have been used to determine the emission of photo-reduced GEM (Brooks et al., 2006) and the fluxes of RGM (Skov et al., 2006), respectively. At Alert, the micrometeorological flux gradient method has been used to determine emission and deposition fluxes of GEM (Cobbett et al., 2007). In Ny-Ålesund, chamber methods have been used to calculate GEM surface emission rates from the change in GEM concentrations in the head space within the chamber (Ferrari et al., 2005). As well, in Ny-Ålesund gradient methods have been used to calculate GEM fluxes during AMDEs (Berg et al., 2003b; Sommar et al., 2007).

While the deposition flux of RGM to the snow pack may be inferred from the springtime increases of total $\mathrm{Hg}$ in surface snow (from near detection limits prior to polar sunrise to, occasionally, several hundred $\mathrm{ng} / \mathrm{L} \mathrm{Hg}$ prior to snow melt), direct micrometeorological measurements of RGM deposition directly to the snow pack was attempted by Skov et al. (2006) at Barrow. This work, between 2001 and 2004, employed REA techniques (Businger and Oncley, 1990; Oncley et al., 1993) and measured RGM on paired $\mathrm{KCl}$ denuders. This task is complicated because the lifetime of RGM is short (Lindberg et al., 2002) and it will rapidly dry deposit to the snow surface, react and/or adsorb onto particles to form $\mathrm{HgP}$ or reduce again to GEM. As well, while the surface aerodynamic resistance of $\mathrm{Hg}$ to deposition increases with colder air temperatures it decreases with wind speed (Brooks et al., 2006). The Skov et al. (2006) measurements showed that RGM deposition fluxes primarily occurred with occasional RGM emissions, yet it is not certain if these were a sampling artifact. In addition, multi-year RGM-REA flux measurements have shown that the snow pack intermittently acts as a source of RGM (Skov et al., 2006). In general, while RGM deposition rates are highest in the afternoon and GEM emissions are highest in the late morning and mid-day, the magnitude of these fluxes vary greatly with episodic fluxes of GEM dominating emissions (Brooks et al., 2006). During a continuous five month study at Alert between January and June 2005 GEM emission fluxes were the highest during the polar night (Cobbett et al., 2007). During the transition period from polar night to polar day, the GEM emission flux was approximately zero and not until June, when the snow was melting quickly and the tundra was visible, were there any significant GEM emission fluxes. These dynamic deposition and re-emission episodes underscore the delicate balance of the Arctic $\mathrm{Hg}$ phenomenon between atmospheric oxidation and deposition on the one hand and snow pack photo-reduction and emission on the other. Seasonal studies at Barrow (Brooks et al., 2006) indicate a springtime RGM deposition of roughly $34 \mathrm{mg}(\mathrm{Hg}) \mathrm{m}^{-2}$ and GEM emission of $\sim 8 \mathrm{mg}(\mathrm{Hg}) \mathrm{m}^{-2}$, netting a surface gain of $26 \mathrm{mg}(\mathrm{Hg}) \mathrm{m}^{-2}$. This is contrary to some publications suggesting a net emission of GEM following depletion events (Lahoutifard et al., 2005; Kirk et al., 2006). At Alert, this hypothesis was investigated with no evidence that there is a net emission of GEM after AMDEs (i.e. GEM emission fluxes are approximately zero following AMDEs). While these limited studies have indicated that roughly one third of the deposited mercury may become available to biota via melt water (Lindberg et al., 2001), disparate sampling times and frequencies, along with inter-annual variability and the representative factors of the measurements, places into question the spatial and temporal extrapolations of these results.

Emission of $\operatorname{Hg}(0)$ from snow surfaces appears to be enhanced by sunlight and temperature (Steffen et al., 2002; Ferrari et al., 2005). In 2003, at $\mathrm{Ny}$-Ålesund, $\mathrm{Hg}$ emission fluxes were reported to range between 0 to $50 \mathrm{ng} / \mathrm{m}^{2} \mathrm{~h}$ using flux chamber techniques. The peak GEM emission flux was recorded after an AMDE but surprisingly, this peak in GEM did not correspond to any commensurate change in $\mathrm{Hg}$ concentration in the surface snow (Ferrari et al., 2005). During periods when AMDEs were not active Ferrari et al. (2005) 
reported that the GEM emission fluxes resulted from the production of GEM within the interstitial snow pack air (between $15-50 \mathrm{ng} / \mathrm{m}^{2} \mathrm{~h}$ in the surface and $0.3-6.5 \mathrm{ng} / \mathrm{m}^{2} \mathrm{~h}$ in the deeper snow layers). During a short field campaign in 2002 in Ny-Ålesund, emission fluxes of GEM were observed around AMDE's. The average flux was $8 \mathrm{ng} / \mathrm{m}^{2} \mathrm{~h}$ and a high mid-day peak was reported as $70 \mathrm{ng} / \mathrm{m}^{2} \mathrm{~h}$ (Berg et al., 2003b; Sommar et al., 2007).

Quantifying $\mathrm{Hg}$ fluxes is essential to understanding the fate of mercury in the Arctic. Based on current knowledge of atmospheric chemistry of $\mathrm{Hg}$ in the Arctic, measuring the GEM flux is insufficient to determine chemical mechanisms. The need for continuous, high resolution fluxes of RGM and $\mathrm{HgP}$ remains. This is a new area of field research in its beginning stages of development (Skov et al., 2006); as analytical methods improve so will the ability to measure and interpret Hg fluxes.

\subsubsection{Mercury in the snow pack}

The fate of $\mathrm{Hg}$, once deposited onto snow and ice packs, is poorly understood and not well studied. This is surprising considering the snow pack acts as a transitional environment between the atmospheric reservoir and ecosystem uptake. In Arctic regions, the snow pack contains a variety of impurities contributed by anthropogenic sources of the northern industrialized countries (Douglas and Sturm, 2004; Poulain et al., 2004; Poulain et al., 2007c). This reservoir of adsorbed or dissolved compounds is not inert but rather plays an active role in photochemical reactions in the snow (Dominé and Shepson, 2002). Snow packs offer large surfaces for which the exchange of $\mathrm{Hg}$ between the air at the lowest point of the atmosphere and the air within the snow pack can occur. Dominé and Shepson (2002) estimate that, considering the global snow cover on the Earth's surface, an air volume equivalent to the volume of the atmosphere passes through snow packs every 4 months. Additionally, snow packs act like a reaction chamber promoting heterogeneous and photochemical reactions. For instance, well known reactions involving $\mathrm{NO}_{\mathrm{x}}$ and $\mathrm{HCHO}$ within the snow pack have been demonstrated (Honrath et al., 1999; Sumner and Shepson, 1999). As a result, reactions that occur within the snow affect both the composition of the snow and the overlying atmosphere.

Both inorganic and organic forms of $\mathrm{Hg}$ are found in snow. The inorganic forms include $\mathrm{Hg}(0)$ and complexes of $\mathrm{Hg}(\mathrm{II})$. Total $\mathrm{Hg}$ consists of all inorganic forms of $\mathrm{Hg}$ measured yet the fraction of $\mathrm{Hg}(0)$ is small (approximately 1 percent of $\mathrm{THg}$ is $\mathrm{Hg}(0)$ ) (Poulain et al., 2004). Reported concentrations of total $\mathrm{Hg}$ in snow are low during polar winter, ranging from 0.1 and $1 \mathrm{ngL}^{-1}$ in Antarctica (Sheppard et al., 1991) and between $<1 \mathrm{ng} / \mathrm{L}$ and $5 \mathrm{ng} / \mathrm{L}$ in the Arctic (Steffen et al., 2002; Aspmo et al., 2005; Ferrari et al., 2005). During AMDEs, at polar sunrise, typical total mercury concentrations in surface snow increase up to maximum values rang- ing between 20 and $100 \mathrm{ng} / \mathrm{L}$ (Lu et al., 2001; Lindberg et al., 2002; Steffen et al., 2002; Berg et al., 2003a; Poulain et al., 2004; Lahoutifard et al., 2005; Lahoutifard et al., 2006). The highest concentration of total $\mathrm{Hg}$ ever reported in polar ecosystem snow $(820 \mathrm{ng} / \mathrm{L})$ was found in surface hoar crystals formed directly from the vapour phase (Douglas et al., 2005).

The only organic form of $\mathrm{Hg}$ currently reported in polar snow is methyl mercury ( $\mathrm{MeHg}$ ), although $\mathrm{Me}_{2} \mathrm{Hg}$ has recently been measured in seawater, no such measurements have been made in snow, though its presence in snow is suspected (Kirk, 2006). Kirk and St. Louis (2006) theorize that $\mathrm{Me}_{2} \mathrm{Hg}$ produced at ocean depths is transported to the surface by ocean upwelling, where it is volatilized, and could be deposited to coastal snow packs (Kirk, 2006; Kirk et al., 2006). Reported levels of $\mathrm{MeHg}$ in snow of the Canadian high Arctic range from 0.02 to $0.28 \mathrm{ng} / \mathrm{L}$ (Kirk, 2006; Kirk et al., 2006) and may represent a significant fraction of the pool of total mercury. MeHg was hypothesized to be partly of marine origin, based on correlations between chloride and MeHg levels (St. Louis et al., 2005). Similarly, Constant et al. (2007) measured MeHg in the snow on the shore of Hudson's Bay and found a positive correlation between $\mathrm{MeHg}$, sulfate and chloride in the snow. The authors suggest that marine aerosols are a source of $\mathrm{MeHg}$ the snow pack in this area.

\subsection{3 $\mathrm{Hg}(0)$ emissions from polar snow packs}

It has become clear that the snow pack is a potential source of GEM to the atmosphere (Steffen et al., 2002; Brooks et al., 2006). Steffen et al. (2002) were one of the first to report measurements of GEM from interstitial air in the snow (a few centimeters below the surface) and showed that the snow pack releases GEM (Steffen et al., 2002). Further field measurements confirmed that GEM emissions were strongly correlated with solar irradiation by demonstrating that diurnal cycles of GEM existed in the interstitial air over a period of several days . In addition, Lahoutifard et al. (2005) found a pronounced diel pattern with GEM concentration gradients between 20 and $150 \mathrm{~cm}$ above the snow pack suggesting concentration gradients were sufficient to sustain rapid fluxes between the atmosphere and the snow. Evidence of GEM production within the interstitial air in the snow was observed throughout the Arctic via interstitial air measurements, snow sampling or a combination of both methods in Barrow, US (Lindberg et al., 2002), Station Nord, Greenland , Ny-Ålesund, Svalbard (Ferrari et al., 2004b; Ferrari et al., 2005; Fain et al., 2006b; Fain et al., 2006a; Sommar et al., 2007) Resolute Bay, Canada (Ariya et al., 2004; Poulain et al., 2004; Lahoutifard et al., 2005), Kuujjuarapik (a subarctic site in Canada) (Dommergue et al., 2003a; Lahoutifard et al., 2006) and on Ellesmere Island, Canada. Concentration of GEM in interstitial snow pack air reported from these studies ranges between 0.4 to $5 \mathrm{ng} / \mathrm{m}^{3}$ yet concentrations up 
to $30 \mathrm{ng} / \mathrm{m}^{3}$ have been observed in the high Arctic (see references above).

Many uncertainties remain about GEM production in the snow pack due to the poor understanding of light penetration inside the snow pack. In the case of UV and visible light, these wavelengths are poorly absorbed but tend to be scattered by the snow. King and Simpson (2001) estimate that $85 \%$ of the photochemical reactions occur in the top $10 \mathrm{~cm}$ of the snow pack. However, this estimate is dependent on the physical shape and temperature of the snow. The presence of GEM in the lower layers of the snow pack was examined by Lahoutifard et al. (2005) who found vertical GEM gradients that suggested transport of mercury to and from the snow pack. The coefficients for molecular diffusivity of $\mathrm{Hg}$ were too low to account for the observed gradients, therefore, the movement of mercury in the snow pack was concluded to be enhanced by the presence of hydrogen peroxide (Lahoutifard et al., 2005).

The continuous production of GEM and its subsequent evasion from the snow may lead to a decrease of the $\mathrm{Hg}$ content of Arctic snow packs over the course of the winter and spring. This has important ramifications in our ability to link $\mathrm{Hg}$ deposition to the snow pack with $\mathrm{Hg}$ available for methylation or ecosystem uptake during spring melt. For example it has been shown that surface snow could lose up to $90 \%$ of its total $\mathrm{Hg}$ content within $48 \mathrm{~h}$ (Poulain et al., 2004) and that emission fluxes could be in the range of a few to hundreds of $\mathrm{ng} / \mathrm{m}^{2} \mathrm{~h}$ (Ferrari et al., 2005). The importance of snow to air transfers of GEM cannot be assessed through shortterm studies because it depends on time dependent factors that include solar irradiation, the chemical composition of the snow, the site characteristics and the snow pack characteristics. Further, as snow melt begins, high GEM emissions in interstitial snow pack air increase to concentration values of more than 10 times that above the surface (Dommergue et al., 2003b; Dommergue et al., 2003a; Cobbett et al., 2007) and this may have an impact on the atmospheric concentration of GEM (Lindberg et al., 2001).

6.2 Redox processes, transformations in snow and photoreduction and photooxidation in fresh and sea water

Once deposited by dry/wet deposition or AMDEs, $\mathrm{Hg}$ species in snow can potentially undergo redox reactions and methylation/demethylation processes. Methylation processes will be discussed below in Sect. 6.3. Reduction of $\mathrm{Hg}(\mathrm{II})$ in snow proceeds mostly through photochemical reactions (Lalonde et al., 2002; Lalonde et al., 2003; Dommergue et al., 2007) as polychromatic experiments indicate major effects within the UV-B wave band. The importance of the reductive process has been exemplified in the Arctic by rapid $\mathrm{Hg}$ losses in the irradiated surface snow layers (Poulain et al., 2004). Since adsorption/desorption processes of $\mathrm{Hg}(0)$ are quite unlikely (Bartels-Rausch et al., 2002), resulting diel cycles of $\operatorname{Hg}(0)$ in interstitial air bring strong evidence for an important post reduction snow to air transfer (Dommergue et al., 2003a; Ferrari et al., 2005). It has been recently suggested that $\mathrm{Hg}$ reduction in snow mostly occurs in the snow crystal quasi-liquid layer and is therefore highly dependent on temperature (Ferrari et al., 2005). However, there is a need for further physical and chemical characterization of this so-called quasi-liquid layer. There have been accounts of $\mathrm{Hg}$ (II) reduction in snow during the night and at depth in the snow pack (Ferrari et al., 2004b). $\mathrm{HO}_{2}$ has been proposed as a reducing agent of $\mathrm{Hg}$ (II) during the day and at night (Dommergue et al., 2003a; Ferrari et al., 2004b). In contrast, an experimental thermochemical study by Gårdfeldt and Jonsson (2003) showed that $\mathrm{Hg}(\mathrm{II})$ is reduced by neither $\mathrm{HO}_{2}$ nor $\mathrm{O}_{2}^{-}$under ambient conditions. Direct photolysis of some $\mathrm{Hg}$ complexes has also been proposed. Oxidation of newly formed $\mathrm{Hg}(0)$ in snow has been reported and was attributed to photochemical processes (Poulain et al., 2004). Based on studies conducted on temperate snow samples, it is likely that this photooxidation is controlled by the presence of halogen radicals in snow (Ariya et al., 2004) and is therefore of importance in coastal snow packs. This reaction is mainly driven by UV-A and UV-B wavebands (Poulain et al., 2004). Studies have also proposed that hydrogen peroxide formed in snow could oxidize $\mathrm{Hg}$ under acidic conditions (Lahoutifard et al., 2006). Further, the significance of biological redox processes in snow has recently been suggested (Hennebelle et al., 2006) and data from arctic ponds formed by snow melt, coastal lagoons and seawater indicate the presence of bacteria that express resistance to $\mathrm{Hg}$ via reduction (Poulain et al., 2007b).

Observations made by Ferrari et al. (2004b) and Fain et al. (2006a, b) in the field showed that $\mathrm{Hg}(0)$ can be significantly depleted inside the snow pack. Other studies indicate that some radicals $(\mathrm{HO}, \mathrm{Cl}, \mathrm{Br})$, first produced by irradiation, may be responsible for $\mathrm{Hg}(0)$ oxidation (Poulain et al., 2004; Fain et al., 2006b; Fain et al., 2006a). However, oxidants leading to the $\operatorname{Hg}(0)$ destruction in the snow-pack are not yet identified.

Finally, if chemical processes have been observed in the snow pack at the surface of the snow grains, microbiological interactions can also take place especially when snow melt starts (Amato et al., 2007). Water layers around the snow grains (Döppenschmidt and Butt, 2000) that are enriched in ions and organic substances are locations where chemistry is enhanced (Takenaka et al., 1992). In these layers, microorganisms can develop efficiently (Ariya et al., 2002a; Amato et al., 2007) and interact with $\mathrm{Hg}$ by adsorption onto the cell or cell walls, as long as genetic material of the microorganism is available for this process (Hennebelle et al., 2006). During the melting period, micro-organisms can generate exopolysaccharides (E.P.S) (Krembs, 2006) which can form strong complexes with metals (Loaec et al., 1998) such as lead, cadmium and zinc (Loaec et al., 1998). The resultant melt water will then likely contain $\mathrm{Hg}$ bound to organic material that could then enter the food chain. 
The oxidation of $\mathrm{Hg}$ can take place in fresh and sea waters (Lalonde et al., 2001; Poulain et al., 2007a). In its oxidized form, $\mathrm{Hg}$ is water soluble and will readily deposit to aqueous systems from the atmosphere through dry and wet processes (e.g. AMDEs). Once the $\mathrm{Hg}$ is transferred into this oxidised state, it can be methylated and is thus available for bioaccumulation. Therefore, it is necessary to identify the lifetime and end products of photodegradation of $\mathrm{Hg}$ in fresh and sea waters. Gårdfeldt et al. (2001) and Lin and Pehkonen (1998) reported that $\mathrm{Hg}(0)$ photoradical aqueous reactions such as $\mathrm{Hg}(0)+\mathrm{OH}$ are fast. As well, reduction of $\mathrm{Hg}$ (II) to $\mathrm{Hg}(0)$ in natural aerated waters, e.g. melted snow, may proceed thermally or under actinic radiation in the presence of a suitable inorganic (e.g. sulphite) or organic (e.g. oxalate) ligands. In these cases, intramolecular transfer of $2 \mathrm{e}^{-}$charge from ligand to metal, possibly involving fragmentation of the ligand, can occur (Van Loon et al., 2000; Van Loon et al., 2001; Gårdfeldt and Jonsson, 2003). Other possible monomeric radical intermediates $\mathrm{Hg}(\mathrm{I}) / \mathrm{HgX}$ from redox processes are efficiently scavenged in aerated solutions by molecular oxygen yielding divalent $\mathrm{Hg}$ species (Lyu et al., 1983; Horvath and Vogler, 1993). Because aqueous phase chemistry of $\mathrm{Hg}$ plays an important role in the removal of $\mathrm{Hg}$ from the atmosphere, studies such as those described above must be considered when trying to understand cycling of $\mathrm{Hg}$ in Polar Regions.

\subsection{Methylation of $\mathrm{Hg}$ in Polar Regions}

Although most of the measurements for mercury in Arctic ecosystems have been for total $\mathrm{Hg}$, it is $\mathrm{MeHg}$ that is the most toxic and environmentally relevant form that biomagnifies in food chains leading to humans. While $\mathrm{MeHg}$ shows a direct bioaccumulation of at least 10000 times between water and particulate material (Watras et al., 1995), the increase in subsequent trophic levels is typically 4 to 6 times (Cabana and Rasmussen, 1994). The fraction of $\mathrm{MeHg}$ to total $\mathrm{Hg}$ also increases progressively with increasing trophic levels (Wagemann et al., 1997).

MeHg production in the Arctic has been documented in wetland soils and streams (Loseto et al., 2004a), in freshwater ponds (St. Louis et al., 2005) and lakes in tundra watersheds (Hammerschmidt et al., 2006b). Sulfate reducing bacteria (SRB) are considered to be the main $\mathrm{Hg}$ methylators in aquatic temperate ecosystems and may play a role in the Arctic soils, streams and lakes; however this assumption requires further testing. Loseto et al. (2004b) collected sediments in Arctic wetlands prior to spring thaw. The MeHg concentration in the frozen sediments was low when they were transported to the laboratory (average $0.065 \mathrm{ng} / \mathrm{g}$ ) but after incubation at 6 and $8^{\circ} \mathrm{C}$ for 30 and 60 days, values increased up to 100 fold in some samples. Although sulfate reduction occurred, SRB abundance was generally low and showed no relationship with $\mathrm{MeHg}$ formation. The dissimilar sulfatereductase gene specific for SRB was found at only one site where the SRB abundance was low. This implies another mechanism for $\mathrm{MeHg}$ formation may be operating. Iron reducing bacteria is also thought to form $\mathrm{MeHg}$ (Flemming et al., 2006) and photochemical (Siciliano et al., 2005) or abiotic formation from methyl donors such as methyl cobalamin, methyl tin or methyl lead are also possible (Celo and Scott, 2005; Celo et al., 2006). Loseto et al. (2004a) further reported a peak in $\mathrm{MeHg}$ concentration immediately following snowmelt in Resolute and found that this peak occurred in drainage basins that were located both in and out of wetlands. This peak of MeHg concentration was also found in the streams during peak runoff. This result was surprising because if the $\mathrm{MeHg}$ is formed in wetlands then maximum $\mathrm{MeHg}$ levels would be expected later in the season during the time of lowest flow where minimal dilution in the water would occur. This finding can be of great importance in the context of climate change. Thus, it was concluded that $\mathrm{MeHg}$ is either formed in the snow or deposited to the snow. In contrast to the high levels of $\mathrm{THg}$ in the snow are associated with AMDEs $(>30 \mathrm{ng} / \mathrm{L})$, the concentration of THg in runoff was low $(<2 \mathrm{ng} / \mathrm{L})$ in wetlands, streams and lakes.

After measuring high $\mathrm{MeHg}$ concentrations in high Arctic snow (up to $280 \mathrm{pg} / \mathrm{L}$ ), St. Louis et al. (2005) proposed that $\mathrm{MeHg}$ may also be produced abiotically from the photochemical breakdown of $\mathrm{Me}_{2} \mathrm{Hg}$ evaded from the ocean. This latter pathway was also demonstrated under laboratory conditions (Niki et al., 1983a) but the relative magnitude of this source of $\mathrm{MeHg}$ to high latitude ecosystems has not been quantified. $\mathrm{MeHg}$ can be produced upon irradiation and in the presence of dissolved organic matter in surface water of temperate lakes (Siciliano et al., 2005). Hence, continuous daylight combined with the presence of biogenic organic matter from heterotrophic activity may lead to the production of $\mathrm{MeHg}$ in polar environments.

$\mathrm{MeHg}$ may also potentially be biologically formed in aerosols or in snow. Constant et al. (2007) suggest that MeHg levels reported on the shore of Hudson's Bay are a result of methylation of THg (at 8-9 ng/L) in snow because of a positive correlation between the high levels measured $(200 \mathrm{pg} / \mathrm{L})$ and heterotrophic bacteria plate counts and particulate material in the snow. Also, It has been suggested that $\mathrm{MeHg}$ may be formed in the atmosphere through a reaction between labile $\mathrm{Hg}$ (II) complexes and an unknown methylating agent(s), potentially acetate or similar molecules (Hammerschmidt et al., 2007). These authors propose that available $\mathrm{Hg}(\mathrm{II})$ limits the reaction and increased atmospheric loadings of $\mathrm{Hg}$ could lead to enhanced $\mathrm{MeHg}$ in precipitation. Indeed, the heterotrophic activity of bacteria and fungi was demonstrated in aerosols and in snow from Spitzbergen (Norway) and at the South Pole. Together with the observation that high levels of bioavailable $\mathrm{Hg}$ were found in snow following AMDEs and considering alternative pathways for $\mathrm{MeHg}$ methylation to those occurring in anoxic conditions, one can expect methylation to occur. In coastal/marine areas, the production of $\mathrm{MeHg}$ and $\mathrm{Me}_{2} \mathrm{Hg}$ by macroalgae from Kongs- 
fjord on Spitzbergen,was reported (Pongratz and Heumann, 1998).

Demethylation of $\mathrm{MeHg}$ has been historically attributed to bacterial processes and photodegradation. In polar areas, Hammerschmidt et al. (2006) provided evidence for an important role of photodemethylation in controlled pools of $\mathrm{MeHg}$ in lakes. The role of microbial demethylation is supported by the expression of mer-operon functions, namely merA genes, in microbial biomass collected from coastal/marine environments.

The impact of the springtime pulse of $\mathrm{MeHg}$ to the high arctic is an important mechanism to understand because of the toxic effects that $\mathrm{MeHg}$ may have on the availability of $\mathrm{MeHg}$ for marine mammal uptake. Further, the influence of climate changes (e.g. warming, thinning and melting of sea ice) on net $\mathrm{MeHg}$ production, most likely through changes in the organic carbon cycle, must be quantified to fully understand the link to this increase in $\mathrm{MeHg}$ production and any connection to the uptake of this pollutant by marine mammals. Perhaps there is sufficient total $\mathrm{Hg}$ in the environment to fuel the methylation process for decades to come because the production of $\mathrm{MeHg}$ will, no doubt, increase with temperature.

\subsection{Mercury in polar waters}

The ocean plays a key role in the biogeochemical cycling of $\mathrm{Hg}$ (Mason and Sheu, 2002) yet there is limited information about the processes occurring with $\mathrm{Hg}$ in Arctic coastal and marine waters (Aspmo et al., 2006) and their contribution to elevated levels of $\mathrm{Hg}$ in Polar Regions. It is now recognized that there is $\mathrm{MeHg}$ in Arctic snow close to marine locations (St. Louis et al., 2005) yet the importance of this $\mathrm{MeHg}$ from marine waters as a source to aquatic food chains has not been established. Leitch et al. (2007) calculated that $15 \mathrm{~kg}$ per year of $\mathrm{MeHg}$ and 2.2 tonnes per year of THg were transported from the Mackenzie River to the Beaufort Sea during the spring freshet. The authors suggest that this river plays a major role in the elevated $\mathrm{Hg}$ concentrations in marine mammals in the Beaufort Sea (Leitch et al., 2007). Other studies have reported THg concentrations averaging $160.5 \pm 88.3 \mathrm{pg} / \mathrm{L}$ from samples collected in the North Atlantic Ocean; more than $400 \mathrm{pg} / \mathrm{L}$ of $\mathrm{THg}$ in surface waters of Toolik Lake, Alaska (Tseng et al., 2004) and more than $35 \mathrm{pg} / \mathrm{L}$ DGM on the North Atlantic at latitudes $>74^{\circ} \mathrm{N}$ and/or regions where the ocean was mostly covered with sea ice (Aspmo et al., 2006). In the latter study, the authors hypothesized that $\mathrm{Hg}$ was exported from melting sea-ice to the surface ocean water. After abiotic and/or biotic reduction during Arctic summer, $\mathrm{Hg}(0)$ accumulated under the sea ice cover and parts of it were re-emitted from water surfaces to the atmosphere during summer. It is not clear from these results if elevated GEM and DGM concentrations reported are the direct consequence of strong input pulses of $\mathrm{Hg}$ to the Arctic Ocean during AMDEs in the months before. In addi- tion to $\mathrm{MeHg}$ being reported in polar oceans $\mathrm{Me}_{2} \mathrm{Hg}$ has been measured in the Arctic Ocean and in Hudsons Bay (Kirk, 2006). $\mathrm{Me}_{2} \mathrm{Hg}$ concentrations were highest in the deepest water samples and almost equal to the level for $\mathrm{MeHg}$, which was also reported higher in the deeper samples. Values were low, near detection limits, in surface samples and thus it remains a challenge to explain the mechanism for transport from deep water to the atmosphere where photodegradation to $\mathrm{MeHg}$ can occur.

The oceans play one of the most significant roles in Polar Regions both in spatial breadth and processes and yet information about dynamics of $\mathrm{Hg}$ around these environments is scarce. Considering that the Arctic Ocean contains a large, vulnerable ecosystem exposed to this toxic pollutant, the vast number of processes that occur in the water column, sediments and ice (e.g. concentrating and methylation of $\mathrm{Hg}$ ) and that change in climate will primarily affect this ocean and beyond, the authors recommend that future research must focus on this area.

\section{Conclusions and future directions}

During the last decade a great leap in our understanding of $\mathrm{Hg}$ transformation in the Arctic and the Antarctic atmosphere has occurred, especially in measurement, laboratory and modeling studies. The goal of this review article is to provide a comprehensive assessment of the state of the $\mathrm{Hg}$ science in Polar Regions since the discovery of AMDEs. Taken in total, these studies frame our current understanding of the roles that atmospheric chemistry, $\mathrm{Hg}$ speciation, $\mathrm{Hg}$ deposition, snow and ice processes and photochemical reactions play in driving the fascinating $\mathrm{Hg}$ cycling in this environment. Prioritizing future research directions is difficult because of the interdisciplinary nature of Polar $\mathrm{Hg}$ studies that incorporate work from atmospheric chemists, sea ice and snow chemists, modelers, laboratory experimentalists and ecosystem biogeochemists. Here we will attempt to summarize where the current state of knowledge lies with an eye to the future research efforts and results that are needed to move the state of knowledge further. We will first start with what is generally considered well known and then will transition toward the major gaps in our knowledge base. As earlier stated, the changing climate and emissions sources over the next 20 years will dramatically affect the source, deposition and long term fate of $\mathrm{Hg}$ deposited to Polar Regions. The effects of these changes on the AMDE processes that deposit $\mathrm{Hg}$ to the Arctic and Antarctic are, as of yet, unknown.

It is well understood that AMDEs occur throughout Polar Regions close to marine locations each spring. Further, research has shown that the initiation of AMDEs requires $\mathrm{Hg}$ in the atmosphere, sunlight and reactive halogens. Sea ice or snow may provide a large pool of halogens to feed the photochemical reactions. Several lines of evidence confirm that $\mathrm{Hg}$ is able to undergo fast kinetic reactions with halogen radicals 
such as $\mathrm{Br}$ and $\mathrm{BrO}$ although $\mathrm{IO}$ and $\mathrm{I}$ have not been ruled out as players. It is agreed that GEM is converted to an inorganic gas phase $\mathrm{Hg}$ species, termed RGM, during AMDEs and this RGM is either associated with aerosols (termed $\mathrm{PHg}$ ) and/or deposited to the snow pack. The fate of this deposited $\mathrm{Hg}$ species is less clear. Some of the deposited RGM is reduced to GEM and subsequently re-emitted to the atmosphere while some remains or is re-oxidised at or within the snow pack. Photochemistry studies of $\mathrm{Hg}$ within the snow pack have shown that reactions occur within the first few centimeters. Flux measurements have shown that there is a net deposition of $\mathrm{Hg}$ to the snow in early spring followed by a net emission of $\mathrm{Hg}$ in the summer. Gas phase $\mathrm{Hg}$ has been measured in interstitial snow pack air and in the atmosphere during nonAMDE periods.

Several models have been developed to incorporate AMDEs into regional and global $\mathrm{Hg}$ assessments. Both process and transport models describe the cycling of $\mathrm{Hg}$ within and into Polar Regions. All the models agree that AMDEs affect the amount of annual $\mathrm{Hg}$ deposited to Polar Regions. With the addition of more long term stations measuring atmospheric $\mathrm{Hg}$ species throughout the Arctic and the Antarctic the models can be greatly refined. However, the largest gap in the current models is a solid understanding of the chemical processes that drive deposition and re-emission of $\mathrm{Hg}$ in this environment.

Because of the link the snow pack has to the local environment, considerable research on the deposition to and processes within this medium have been done. This work covers a wide spatial extent as research sites in numerous Arctic and Antarctic locations have been employed. However, few of these studies are part of long term study sites. This research has demonstrated the heterogeneity of $\mathrm{Hg}$ distribution in the snow pack and that both physical conditions and chemical processes must be accounted for in the assessment of the fate of $\mathrm{Hg}$ within the snow pack. Transects inland away from the ocean demonstrate higher $\mathrm{Hg}$ concentrations in the snow at locations closer to marine water. Of great significance, $\mathrm{MeHg}$ has been found at elevated levels in snow close to marine waters and this may represent a significant fraction of the pool of total $\mathrm{Hg}$. Whatever the source of $\mathrm{MeHg}$ in the Arctic, it is recognized that substantial amounts of it exist in polar environments but the link to the aquatic and marine food chains has yet to be resolved. Further, $\mathrm{Hg}$ and $\mathrm{MeHg}$ may be available as a large pulse emitted from the snow pack during spring melt events. Many studies have focused on the primary deposition of $\mathrm{Hg}$ to snow and ice and the link to atmospheric chemical processes. Some of these have been coupled to re-emission measurements that suggest much of the $\mathrm{Hg}$ deposited during AMDEs is lost to the atmosphere during photochemical reduction and, perhaps, also during snow melt and snow metamorphism. However, detailed investigations tracking $\mathrm{Hg}$ in the snow pack and surface water before and after spring melt are needed. Further, lake, tundra and marine sediments and ice cores provide a long term record of $\mathrm{Hg}$ deposition that can be used to compare pre- and postindustrial revolution deposition rates. More work to incorporate these studies for long term background $\mathrm{Hg}$ deposition in order to compare future $\mathrm{Hg}$ deposition rates, in light of climate warming and changing emissions sources, will be required. The study of methylation processes occurring in Polar Regions has been put in the forefront of importance and is gaining momentum within the research community. It is clear that the formation of $\mathrm{MeHg}$ may be intimately linked to a warming climate because both the processes of methylation and demethylation will be altered by this change, thus every attempt should be made to understand what is controlling these methylation processes and establish what drives these controls in order to determine the impacts of climate change on the polar environment.

The role of the sea ice in the cycling of atmospheric $\mathrm{Hg}$ has been closely studied and has shown to provide a viable source of halogens and a location for AMDE chemistry to occur. Some research on $\mathrm{Hg}$ in and into the Arctic Ocean and Hudson's Bay indicates that these bodies of water are vital to the $\mathrm{Hg}$ cycle. Initial work has begun on the microbiological transformations of $\mathrm{Hg}$ in aquatic systems and their effect on Hg distribution in Polar Regions. Since microbiological processes likely drive the methylation and biological uptake of $\mathrm{Hg}$ these studies must be continued both in the field and in laboratory controlled environments.

While there has been a tremendous amount of research undertaken since the discovery of AMDEs, several key questions remain that limit a complete understanding $\mathrm{Hg}$ cycling in Polar Regions. In the following paragraphs, the authors present suggestions on where future research should be directed in order to gain this desired comprehensive understanding of $\mathrm{Hg}$ cycling in this region.

One critical gap of knowledge is the lack of proper field methodology for atmospheric $\mathrm{Hg}$ speciation in environmental matrices, including air, snow and aerosols. Of most significance is the identification of the exact chemical structure of the Hg species produced during AMDEs. This is essential to know before properly addressing the global cycling of $\mathrm{Hg}$, including the Polar Regions, in order to know which species are involved in the chemical, physical and biological transformations in the environment. We strongly recommend development of novel techniques to efficiently address $\mathrm{Hg}$ speciation in Polar Regions (as well as within other environmental conditions). Additionally, it is vital to understand exactly how and where the atmospheric products are produced not only in the boundary layer but also throughout the free troposphere. This is very relevant to understanding the impact of a rapidly changing climate in Polar Regions and the effect these changes will have on the availability of $\mathrm{Hg}$ to enter this ecosystem. Stable mercury isotopes provide a promising tool to monitor $\mathrm{Hg}$ deposition processes and to track $\mathrm{Hg}$ methylation and incorporation into ecosystems. Studies that make use of stable $\mathrm{Hg}$ isotopes may be able to link atmospheric, cryospheric and biologic processes and as 
a consequence their further refinement and application are encouraged.

Modeling and predicting the loading of $\mathrm{Hg}$ to polar ecosystems is challenging because there are several drivers of the $\mathrm{Hg}$ cycle currently undergoing rapid change. Firstly, the source regions of $\mathrm{Hg}$ in the Northern hemisphere are shifting from North America and Western Europe to Asia and Eastern Europe. Models have shown that air currents from Asia occur in the springtime when atmospheric $\mathrm{Hg}$ chemistry is in full swing and any increases in the amount of $\mathrm{Hg}$ from this important source region will, no doubt, affect the $\mathrm{Hg}$ cycle of the Arctic. Secondly, and very importantly, is that the extent of sea ice is in marked decline in certain Arctic regions and the degree to which this decline occurs is predicted to be high. Sea ice drives the major meteorological components of the Arctic system (precipitation, temperature, winds, and regional circulation) and these parameters largely control the entry and subsequent scavenging of atmospheric contaminants including $\mathrm{Hg}$. Changes in the timing and extent of sea ice will no doubt affect AMDE dynamics. It is essential to fully comprehend the role that sea ice plays in AMDE chemistry and subsequent deposition to the ocean. Thus, field campaigns, as well as laboratory and theoretical calculations, must continue to further elucidate the sea ice $\mathrm{Hg}$ interactions and its potential global impact. As well, the changing dynamics of this aspect of $\mathrm{Hg}$ chemistry in the Arctic will only be understood with a denser network of long term $\mathrm{Hg}$ monitoring sites.

A significant gap in our understanding of $\mathrm{Hg}$ cycling in Polar Region lies in our understanding of how mercury enters the upper ocean water from the atmosphere. One third of the Artic is covered by the oceans yet we know very little about their role in $\mathrm{Hg}$ cycling. How the deposition of $\mathrm{Hg}$ to the oceans from the atmosphere (and how that material is further fed into this vulnerable ecosystem) will be altered by change in ice climate is of great significance and relies almost completely on water-column work that has not been undertaken. Further, more work on the biological uptake of $\mathrm{Hg}$ by the ecosystem from the air/snow and water is required.

Human dynamics investigations have increasingly shown that people in the Arctic have elevated Hg in their country food diets. $\mathrm{MeHg}$ is the toxic form of $\mathrm{Hg}$ that dictates the accumulation of mercury in polar environments. While an influx of research on the subject of the processes under which MeHg is produced in polar environments have surfaced, these processes remain not well understood. Some have suggested microbiological transformations of mercury in aquatic systems, others have suggested photochemical reactions and $\mathrm{Me}_{2} \mathrm{Hg}$ evolution from the ocean, yet no direct conclusions have been made. In light of new evidence on the role of biological aerosols the redox reaction of $\mathrm{Hg}$ around these bioaerosols is an area of interest for future research. Atmospheric redox mechanisms of $\mathrm{Hg}$ at the air-snow interface, in clouds and fog and in melting snow are desired because they are also not fully understood. It may be possible to employ $\mathrm{Hg}$ as an environmental tracer to gain a better understanding of fundamental ecosystem processes. This is an arena where $\mathrm{Hg}$ isotopes may provide new and novel information.

Multidisciplinary investigations combining soil and ice microbiology, atmospheric chemistry, oceanography and laboratory investigations may provide the greatest breakthroughs in assessing the long term fate of $\mathrm{Hg}$ in the Polar ecosystems. These types of studies are likely the most sorely needed as they will move the current research across disciplines to provide a better understanding of Polar Regions processes and the fate of contaminants. Results from focused investigations of $\mathrm{Hg}$ deposition and ecosystem processes are likely to yield new and novel information on many unique processes in the Polar Regions. Similarly, investigations tracking the sources and fate of other contaminants such as POPs and other trace metals are likely to yield critical information in atmospheric chemical processes, snow and sea ice melt processes and trophic level relationships.

It is essential to quantify transfer functions from the atmosphere to snow and ice and from melt runoff to soil and aquatic microbiology to gain a better assessment of how the Arctic will respond to changing source regions and a warming climate. We will move the state of understanding forward when the entire system is investigated and a series of synthesis efforts are combined into a strong cohesive assessment of the Polar Region as a whole. Future research on Hg in Polar Regions must focus on discussing the processes and pathways of this contaminant in the context of climate change. With the onset of the International Polar Year, the next ten years of $\mathrm{Hg}$ chemical investigations in the Polar Regions will be exciting and will no doubt incorporate investigators representing many research disciplines. In the end, the authors hope that the next decade will move the science toward a better overall comprehension of arctic system processes.

Acknowledgements. This paper arose from a meeting held at LGGE, Grenoble, in May 2006. It was sponsored by the International Global Atmospheric Chemistry program (IGAC), the British Antarctic Survey, LGGE, Région Rhone-Alpes, Université Jopseph Fourier and the city of Grenoble. This paper is a contribution to the IGAC task on Air-Ice Chemical Interactions (AICI). The authors thank IGAC and AICI as the largest sponsors and organizers. The authors also greatly appreciate and thank the IGAC European office, ISAC-CNR for their financial support. Robie MacDonald and an anonymous reviewer are acknowledged for their detailed and exhaustive constructive comments and suggestions that have greatly improved the manuscript. Numerous discussions with other researchers working on $\mathrm{Hg}$ contamination, the Polar Regions and atmospheric chemistry helped frame the content of this work. The Arctic mercury research community would like to thank the Arctic Monitoring and Assessment Programme (AMAP) for their ongoing support to this field of research over the past several years. AMAP plays an important role in polar research and we thank them for their continued support. AS thanks Environment Canada and the Canadian Northern Contaminants Program for funding support. As well, many thanks to E. Wolff who has showed great patience 
over the past year! TD thanks the US National Science Foundation Office of Polar Programs and the US Army Alaska. MEG thanks the National Science Faculty, SDU.

Edited by: P. B. Shepson

\section{References}

Akeredolu, F., Barrie, L. A., Olson, M. P., Oikawa, K. K., and Pacyna, J. M.: The flux of anthropogenic trace metals into the Arctic from the mid-latitudes in 1979/80, Atmospheric Environment, Atmos. Environ., 28, 1557-1572, 1994.

Alam, A. and Curry, J.: Lead-induced atmospheric circulations, J. Geophys. Res., 100(C3), 4643-4651, 1995.

Amato, P., Hennebelle, R., Magand, O., Sancelme, M., Delort, A.M., Barbante, C., Boutron, C. F., and Ferrari, C.: Bacterial characterization of the snow cover in Svalbard, Spitzberg, FEMS Microbiol Ecol, 59, 2, 255-264, 2007.

Amyot, M., Lean, D., and Mierle, G.: Photochemical formation of volatile mercury in high Arctic lakes, Environ. Toxicol. Chem., 16, 10, 2054-2063, 1997.

Amyot, M., Auclair, J. C., and Poissant, L.: In situ high temporal resolution analysis of elemental mercury in natural waters, Analytica Chimica Acta, 447, 153-159, 2001.

Amyot, M., Southworth, G., Lindberg, S. E., Hintelmann, H., Lalonde, J. D., Ogrinc, N., Poulain, A. J., and Sandilands, K. A.: Formation and evasion of dissolved gaseous mercury in large enclosures amended with ${ }^{200} \mathrm{HgCl}_{2}$, Atmos. Environ., 38, 42794289, 2004.

Andreas, E. L., Guest, P. S., Persson, P. O. G., Fairall, C. W., Horst, T. W., Moritz, R. E., and Semmer, S. R.: Near-surface water vapor over polar sea ice is always near ice saturation, J. Geophys. Res., 107(C10), doi:10.1029/2000JC000411, 2002.

Ariya, P., Dastoor, A., Amyot, M., Schroeder, W., Barrie, L., Anlauf, K., Raofie, F., Ryzhkov, A., Davignon, D., Lalonde, J., and Steffen, A.: The Arctic: A sink for mercury, Tellus B, 56, 5, 397-403, 2004.

Ariya, P. A., Nepotchatykh, O., Igntova, O., and Amyot, M.: Microbiological degradation of organic compounds in the atmosphere, Geophys. Res. Lett., 29, 341-344, 2002a.

Ariya, P. A., Khalizov, A., and Gidas, A.: Reactions of Gaseous Mercury with Atomic and Molecular Halogens: Kinetics, Product Studies, and Atmospheric Implications, J. Phys. Chem. A, 106, 7310-7320, 2002b.

Ariya, P. A., Peterson, K., and Pirrone, N. (Eds.): Atmospheric Chemical Transformation of Elemental Mercury, in: Mercury in Environment, Chap. 13, Springer Science and Business Media, 319 pp., 2005.

Arnold, D., Ayotte, P., Bondy, G., Chan, L., Dewailly, E., Furgal, C., Gill, U., Kalhok, S., Kuhnlein, H., Loring, E., Muckle, G., Myles, E., Receveur, O., Stokker, Y., and Tracy, B.: Canadian Arctic Contaminants Assessment Report II: Human Health, Indian Affairs and Northern Development, Ottawa, 127 pp., 2003.

Aspmo, K., Gauchard, P.-A., Steffen, A., Temme, C., Berg, T., Bahlmann, E., Banic, C., Dommergue, A., Ebinghaus, R., Ferrari, C., Pirrone, N., Sprovieri, F., and Wibetoe, G.: Measurements of atmospheric mercury species during an international study of mercury depletion events at Ny-Alesund, Svalbard, spring 2003. How reproducible are our present methods?, Atmos. Environ., 39, 7607-7619, 2005.

Aspmo, K., Temme, C., Berg, T., Ferrari, C., Gauchard, P.-A., Fain, P.-A., and Wibetoe, G.: Mercury in the Atmosphere, Snow and Melt Water Ponds in the North Atlantic Ocean during Arctic Summer, Environ. Sci. Technol., 40, 13, 4083-4089, 2006.

Bacon, C. E., Jarman, W. M., and Cossa, D. P.: Organochlorine and polychlorinated biphenyl levels in pinniped milk from the Arctic, the Antarctic, California and Australia, Chemosphere, 24, 6, 779-791, 1992.

Baeyens, W.: Speciation of mercury in different compartments of the environment, Trac.-Trend Anal. Chem., 11, 245-254, 1992.

Balabanov, N. B., Shepler, B. C., and Peterson, K.: Accurate global potential energy surface and reaction dynamics for the ground state of HgBr2, J. Phys. Chem.-US, 109, 39, 8765-8773, 2005.

Banic, C., Beauchamp, S. T., Tordon, R. J., Schroeder, W. H., Steffen, A. and Anlauf, K. A.: Vertical distribution of gaseous elemental mercury in Canada, J. Geophys. Res., 108(D9), 4264, doi:10.1029/2002JD002116, 2003.

Bard, S. M.: Global transport of anthropogenic contaminants and the consequences for the Arctic marine ecosystem, Mar. Pollut. Bull., 38, 5, 356-379, 1999.

Bargagli, R., Agnorelli, C., Borghini, F., and Monaci, F.: Enhanced deposition and bioaccumulation of mercury in antarctic terrestrial ecosystems facing a coastal polynya, Environ. Sci. Technol., 39, 21, 8150-8155, 2005.

Barnston, A. G. and Livezey, R. E.: Classification, Seasonality and Persistence of Low-Frequency Atmospheric Circulation Patterms, Mon. Weather Rev., 115, 1083-1126, 1987.

Barrie, L. A.: Arctic air pollution: An overview of current knowledge, Atmos. Environ., 20, 4, 643-663, 1986.

Barrie, L. A., Bottenheim, J. W., Schnell, R. C., Crutzen, P. J.. and Rasmussen, R. A.: Ozone destruction and photo-chemical reactions at polar sunrise in the lower Arctic atmosphere, Nature, 334, 138-141, 1988.

Barrie, L. A., Olson, M. P., and Oikawa, K. K.: The flux of anthropogenic sulphur into the Arctic from mid-latitudes in 1979/80, Atmos. Environ., 23, 11, 2505-2512, 1989.

Bartels-Rausch, T., Jöri, M., and Ammann, M.: Adsorption of mercury on crystalline ice, Annual Report, Laboratory for radiochemistry and environmental chemistry-Paul Scherrer Institut, Villigen, Switzerland, 2002.

Bauer, D., Campuzano-Jost, P., and Hynes, A. J.: Rapid, ultrasensitive detection of gas phase elemental mercury under atmospheric conditions using sequential two-photon laser induced fluorescence, J. Environ. Monitor., 4, 3, 339-343, 2002.

Bauer, D., D’Ottone, L., Campuzaon-Jos, P., and Hynes, A. J.: Gas phase elemental mercury: a comparison of LIF detection techniques and study of the kinetics of reaction with the hydroxyl radicals, J. Photoch. Photobio., 157, 247-256, 2003.

Bennet, M., Edner, H., Grönlund, R., Sjöholm, M., Svanberg, S., and Ferrara, R.: Joint application of doppler LIDAR and differential absorption LIDAR to estimate the mercury flux from a chlor-alkali plant, Atmos. Environ., 40, 664-673, 2006.

Berg, T., Sekkesæter, S., Steinnes, E., Valdal, A. K., and Wibetoe, G.: Springtime depletion of mercury in the European Arctic as observed at Svalbard, Sci. Total Environ., 304, 43-51, 2003 a.

Berg, T., Sommar, J., Wängberg, I., Gårdfeldt, K., Munthe, J., and Schroeder, W. H.: Arctic mercury depletion events at two eleva- 
tions as observed at the Zeppelin Station and Dirigibile Italia , Ny-Ålesund, spring 2002, J. Phys. IV, 107, 151-154, 2003 b.

Berg, T., Kallenborn, R., and Manø, S.: Temporal trends in atmospheric heavy metal and organochlorine concentrations at Zeppelin, Svalbard, Arct. Antarct. Alp. Res., 3, 284-291, 2004.

Bindler, R., Renberg, I., Appleby, P. G., Anderson, N. J., and Rose, N. L.: Mercury accumulation rates and spatial patterns in lake sediments from west Greenland: a coast to ice margin transect, Environ. Sci. Technol., 35, 1736-1741, 2001.

Bloom, N. and Fitzgerald, W. F.: Determination of volatile mercury species at the picogram level by low-temperature gas chromatography with cold-vapour atomic fluorescence detection, Analytica Chimica Acta, 208, 151-161, 1988.

Bossi, R., Riger, F. F., and Dietz, R.: Temporal and spatial trends pf perfluorinated compounds in ringed seals (Phoca hispids) from Greenland, Environ. Sci. Technol., 39, 7416-7422, 2005.

Bottenheim, J. and Chan, H. M.: A trajectory study into the origin of spring time Arctic boundary layer ozone depletion, J. Geophys. Res., 111, D19301 doi:10.1029/2006JD007055, 2006.

Bottenheim, J. W., Gallant, A. G., and Brice, K. A.: Measurements of NOy species and O3 at 82oN latitude, Geophys. Res. Lett., 22, 599-602, 1986.

Boutron, C. F., Vandal, G. M., Fitzgerald, W. F., and Ferrari, C. P.: A forty-year record of mercury in central Greenland snow, Geophys. Res. Lett., 25, 3315-3318, 1998.

Brooks, S. B., Saiz-Lopez, A., Skov, H., Lindberg, S. E., Plane, J. M. C., and Goodsite, M. E. G.: The mass balance of mercury in the springtime arctic environment, Geophys. Res. Lett., 33, L13812, doi:10.1029/2005GL025525, 2006.

Brosset, C.: The behaviour of mercury in the physical environment, Water Air Soil. Poll., 34, 145-166, 1987.

Businger, J. A. and Oncley, S. P.: Flux Measurement with Conditional Sampling, J. Atmos. Ocean Tech., 7, 2, 349-352, 1990.

Cabana, G. and Rasmussen, J. B.: Modelling food chain structure and contaminant bioaccumulation using stable nitrogen isotopes, Nature, 372, 255-257, 1994.

Cai, Y., Monsalud, S., Jaffe, R., and Jones, R. D.: Gas Chromatographic determination of organomercury following aqueous derivatization with sodium tetraethylborate and sodium tetraphenylborate-comparitive study of gas chromatography coupled with aromatic fluorescence spectrometry, atomic emission spectrometry and mass spectrometry, J. Chromatogr. A, A 876, 147-155, 2000.

Calvert, J. G. and Lindberg, S. E.: A study of the potential influence of iodine containing compounds in the extent of ozone depletion in the troposphere in the polar spring I, Atmos. Environ., 38, 30, 5087-5104, 2004a.

Calvert, J. G. and Lindberg, S. E.: The potential influences of iodine containing compounds on the chemistry of the troposphere in the polar spring II, Atmos. Environ., 38, 30, 5105-5116, 2004b.

Celo, V. and Scott, S. L.: Kinetics and mechanism of $\mathrm{Hg}(\mathrm{II})$-assisted hydrolysis of methyl iodide, Inorg. Chem., 44, 7, 2507-2512, 2005.

Celo, V., Scott, S., and Lean, D. R. S.: Abiotic pathways of mercury methylation in the aquatic environment, Sci. Total Environ., 368, 126-137, 2006.

Cheng, M. D. and Schroeder, W. H.: Potential atmospheric transport pathways for mercury measured in the Canadian high arctic, $\mathrm{J}$. Atmos. Chem., 35, 101-107, 2000.
Christensen, J. H., Brandt, J., and Frohn, L. M. S., H.: Modelling of mercury in the Arctic with the Danish Eulerian hemispheric model, Atmos. Chem. Phys., 4, 2251-2257, 2004, http://www.atmos-chem-phys.net/4/2251/2004/.

Cobbett, F. D., Steffen, A., Lawson, G., and Van Heyst, B. J.: GEM fluxes and atmospheric mercury concentrations (GEM, RGM and $\mathrm{HgP}$ ) in the Canadian Arctic at Alert, Nunavut, Canada (February-June 2005), Atmos. Environ., 41, 33, 6527-6543, 2007.

Cobos, D. R., Baker, J. M., and Nater, E. A.: Conditional sampling for measuring mercury vapor fluxes, Atmos. Environ., 36, 27, 4309-4321, 2002.

Colbeck, S. C.: Classification of seasonal snow cover crystals, Water Resour. Res., 22, 9, 59S-70S, 1986.

Constant, P., Poissant, L., Villemur, R., and Lean, D.: Fate of mercury and methylmercury within the snow cover at Whapmagoostui-Kuujjuarapik (Québec, Canada), J. Geophys. Res.-Atmos., 112, 8, D08309, doi:10.1029/2006JD007961, 2007.

Coquery, M., Cossa, D., and Martin, J. M.: The distribution of dissolved and particulate mercury in three Siberian estuaries and adjacent Arctic coastal waters, Water Air Soil Poll., 80, 1-4, 653664, 1995a.

Coquery, M., Cossa, D., and Martin, J. M.: The distribution of dissolved and particulate mercury in three Siberian estuaries and adjacent Arctic coastal waters, Water Air Soil Poll., 80, 1-4, 653664, 1995b.

Costa, M. and Liss, P.: Photoreduction and evolution of mercury from seawater, Sci. Total Environ., 261, 125-135, 2000.

Dastoor, A. P. and Pudykiewicz, J.: A numerical global meteorological sulfur transport model and its application to Arctic air pollution, Atmos. Environ., 30, 9, 1501-1522, 1996.

Dastoor, A. P. and Larocque, Y.: Global circulation of atmospheric mercury: A modeling study, Atmos. Environ., 38, 147-161, 2004.

Demuth, N. and Heumann, K. G.: Validation of Methylmercury Determinations in Aquatic Systems by Alkyl Derivatization Methods for GC Analysis Using ICP-IDMS, Anal. Chem., 73, 16, 4020-4027, 2001.

Derome, J., Fairbrothers, A., Marcy, S., Wirtz, J., and Harding, K.: Bilogocal effects, AMAP, Oslo, Norway, 122, 2005.

Dewailly, E., Ayotte, P., Bruneau, S., Laliberte, C., Muir, D. C. G., and Norstrom, R. J.: Innuit Exposure to Organocholorines through the Aquatic Food Chain in Arctic Quebec, Environ. Health Persp., 101, 7, 618-620, 1991.

Dominé, F. and Shepson, P. B.: Air-Snow Interactions and Atmospheric Chemistry, Science, 297, 5586, 1506-1510, 2002.

Dommergue, A., Ferrari, C. P., Poissant, L., Gauchard, P.-A., and Boutron, C. F.: Chemical and photochemical processes at the origin of the diurnal cycle of gaseous mercury within the snowpack at Kuujjuarapik, Québec, Environ. Sci. Technol., 37, 3289_ 3297, 2003a

Dommergue, A., Ferrari, C. P., Gauchard, P.-A., Boutron, C. F., Poissant, L., Pilote, M., Jitaru, P., and Adams, F.: The fate of mercury species in a sub-arctic snow-pack during snowmelt, Geophys. Res. Lett., 30, 1621, doi:10.1029/2003GL017308, $2003 b$.

Dommergue, A., Ferrari, C., and Boutron, C. F.: First investigation of an original device dedicated to the determination of gaseous 
mercury in interstitial air in snow, Anal. Bioanal. Chem., 375, 106-111, 2003c.

Dommergue, A., Bahlmann, E., Ferrara, R., and Boutron, C. F.: Laboratory simulation of $\mathrm{Hg}^{0}$ emissions from a snowpack, Anal. Bioanal. Chem., 388, 319-327, 2007.

Donohoue, D. L., Bauer, D., and Hynes, A. J.: Temperature and pressure dependent rate coefficients for the reaction of $\mathrm{Hg}$ with $\mathrm{Cl}$ and the reaction of $\mathrm{Cl}$ with $\mathrm{Cl}$ : A pulsed laser photolysispulsed laser induced fluorescence study, J. Phys. Chem. A, 109, 34, 7732-7741, 2005.

Donohoue, D. L., Bauer, D., Cossairt, B., and Hynes, A. J.: Temperature and pressure dependent rate coefficients for the reaction of $\mathrm{Hg}$ with $\mathrm{Br}$ and the reaction of $\mathrm{Br}$ with $\mathrm{Br}$ : A pulsed laser photolysis-pulsed laser induced fluorescence study, J. Phys. Chem. A, 110, 21, 6623-6632, 2006.

Döppenschmidt, A. and Butt, H.-J.: Measuring the Thickness of the Liquid-like Layer on Ice Surfaces with Atomic Force Microscopy, Langmuir, 16, 6709-6714, 2000.

Douglas, T., Sturm, M., Simpson, W., Blum, J., Alvarez-Aviles, L., Keeler, G., Perovich, D., Biswas, A., and Johnson, K.: The influence of snow and ice crystal formation and accumulation on mercury deposition to the Arctic, Environ. Sci. Technol., 42, 1542-1551, 2008.

Douglas, T. A. and Sturm, M.: Arctic haze, mercury and the chemical composition of snow across western Alaska, Atmos. Environ., 38, 805-820, 2004.

Douglas, T. A., Sturm, M., Simpson, W., Brooks, S., Lindberg, S., and Perovich: Elevated mercury measured in snow and frost flowers near arctic sea ice leads, Geophys. Res. Lett., 32, L04502, doi:10.1029/2004GL022132, 2005.

Ebinghaus, R., Jennings, S. G., Schroeder, W. H., Berg, T., Donaghy, T., Ferrara, R., Guentzel, J., Kenny, D., Kock, H. H., Kvietkus, K., Landing, W., Mazzolai, B., Mühleck, Munthe, J., Prestbo, E. M., Schneeberger, D., F., S., Sommar, J., Urba, A., Wallschläger, D., and Xiao, Z.: International field intercomparison measurements of atmospheric mercury species at Mace Head, Ireland, Atmos. Environ., 33, 3063-3073, 1999.

Ebinghaus, R., Kock, H. H., Temme, C., Einax, J. W., Lowe, A. G., Richter, A., Burrows, J. P., and Schroeder, W. H.: Antarctic springtime depletion of atmospheric mercury, Environ. Sci. Technol., 36, 1238-1244, 2002.

Eckhardt, S., Stohl, A., Beirle, S., Spichtinger, N., James, P., Forster, C., Junker, C., Wagner, T., Platt, U., and Jennings, S. G.: The North Atlantic Oscillation controls air pollution transport to the Arctic, Atmos. Chem. Phys., 3, 1769-1778, 2003, http://www.atmos-chem-phys.net/3/1769/2003/.

Eisler, R.: Mercury hazards to fish, wildlife, and invertebrates: a synoptic review, U.S. Fish and Wildlife Service Biological Report 85, 1.12, 90, 1987.

Engstrom, D. R. and Swain, E. B.: Recent declines in atmospheric mercury deposition in the upper Midwest, Environ. Sci. Technol., 312, 960-967, 1997.

Eyrikh, S., Schwikowski, M., Gaggeler, H. W., Tobler, L., and Papina, T.: First mercury determination in snow and firn from highmountain glaciers in the Siberian Altai by CV-ICP-MS, J. Phys. IV, 107, 431-434, 2003.

Fain, X., Ferrari, C. P., Gauchard, P.-A., Magand, O., and Boutron, C. F.: Fast depletion of elemental gaseous mercury in the kongsvegen Glaciersnowpack in Svalbard, Geophys. Res. Lett.,
33, L06826, doi:10.1029/2005GL025223, 2006 a.

Fain, X., Ferrari, C., Gauchard, P.-A., Magand, O., and Boutron, C. F.: Erratum: "Fast depletion of gaseous elemental mercury in the Kongsvegen Glacier snowpack in Svalbard" (Geophysical Research Letters (2006) doi:10.1029/2005GL025223), Geophys. Res. Lett., 33, 20, L20807, doi:10.1029/2006GL027615, 2006 b.

Feng, X., Sommar, J., Gardfeldt, K., and Lindqvist, O.: Improved determination of gaseous divalent mercury in ambient air using $\mathrm{KCl}$ coated denuders, Fresen J. Anal. Chem., 366, 423-428, 2000.

Feng, X., Lu, J. Y., Hao, Y., Banic, C., and Schroeder, W. H.: Evaluation and applications of a gaseous mercuric chloride source, Anal. Bioanal. Chem., 376, 1137-1140, 2003.

Ferrara, R., Ebinghaus, R., Turner, R. R., Lacerda, D., Vasiliev, O., and Salomons, W. (Eds.): Mercury mines in Europe: Assessment of Emissions and Natural Contamination, in: Mercury Contaminated Sites-Characterization, Risk Assessment and Remediation, ISBN 3-540-63731-1, Editors, Springer Verlag 1999, Berlin Heidelberg New York, 51-72, 1999.

Ferrari, C. P., Dommergue, A., and Boutron, C. F.: Profiles of mercury in the snow pack at Station Nord, Greenland shortly after polar sunrise, Geophys. Res. Lett., 31, L03401, doi:10.1029/2003GL018961, 2004a.

Ferrari, C. P., Dommergue, A., Boutron, C. F., Skov, H., Goodsite, M., and Jensen, B.: Nighttime production of elemental gaseous mercury in interstitial air of snow at Station Nord, Greenland., Atmos. Environ., 38, 2727-2735, 2004b.

Ferrari, C. P., Gauchard, P. A., Dommergue, A., Magand, O., Nagorski, S., Boutron, C. F., Temme, C., Bahlmann, E., Ebinghaus, R., Steffen, A., Banic, C., Aspmo, K., Berg, T., Planchon, F., and Barbante, C.: Snow to air exchange of mercury in an Arctic seasonal snow pack in Ny-Alesund, Svalbard, Atmos. Environ., 39, 7633-7645, 2005.

Fitzgerald, W. F. and Gill, G. A.: Sub-nanogram determination of mercury by a 2-stage gold amalgamation and gas-phase detection applied to atmospheric analysis, Anal. Chem., 51, 1714-1720, 1979.

Fitzgerald, W. F., Engstrom, D. R., Mason, R. P., and Nater, E. A.: The case for atmospheric mercury contamination in remote areas, Environ. Sci. Technol., 32, 1-7, 1998.

Fitzgerald, W. F., Engstrom, D. R., Lamborg, C. H., Tseng, C.-M., and Balcom, P. H.: Modern and historic atmospheric mercury fluxes in northern Alaska: global sources and Arctic depletion, Environ. Sci. Technol., 39, 557-568, 2005.

Flemming, E. J., Mack, E. E., Green, P. G., and Nelson, D. C.: Mercury methylation from unexpected sources: Molybdate-inhibited freshwater sediments and an iron-reducing bacterium, Appl. Environ. Microb., 72, 457-464, 2006.

Frieß, U., Hollwedel, J., König-Langlo, G., Wagner, T., and Platt, U.: Dynamics and chemistry of tropospheric bromine explosion events in the Antarctic coastal region, J. Geophys. Res., 109, D06305, 2004.

Garbarino, J. R., Snyder-Conn, E., Leiker, T. J., and Hoffman, G. L.: Contaminants in Arctic snow collected over sea ice, Water Air Soil Poll., 139, 183-214, 2002.

Gårdfeldt, K., Sommar, J., Strömberg, D., and Feng, X. B.: Oxidation of atomic mercury by hydroxyl radicals and photoinduced decomposition of methylmercury in the aqueous phase, Atmos. Environ., 35, 17, 3039-3047, 2001. 
Gårdfeldt, K., Horvat, M., Sommar, J., Kotnik, J., Fajon, V., Wangberg, I., and Lindqvist, O.: Comparison of procedures for measurements of dissolved gaseous mercury in seawater performed on a Mediterranean cruise, Anal. Bioanal. Chem., 374, 1002$1008,2002$.

Gårdfeldt, K. and Jonsson, M.: Is bimolecular reduction of divalent mercury complexes possible in aqueous systems of environmental importance?, J. Phys. Chem. A, 109, 4478-4482, 2003.

Gauchard, P. A., Aspmo, K., Temme, C., Steffen, A., Ferrari, C. P., Berg, T., Ström, J., Kaleschke, L., Dommergue, A., Bahlmann, E., Magand, O., Planchon, F., Ebinghaus, R., Banic, C., Nagorski, S., Baussand, P., and Boutron, C. F.: Study of the origin of atmospheric mercury depletion events recorded in Ny-Ålesund, Svalbard, spring 2003, Atmos. Environ., 39, 76207632, 2005.

Giesy, J. P. and Kannan, K.: Global Distribution of Perfluorooctane Sulfonate in Wildlife, Environ. Sci. Technol., 35, 1339-1342, 2001

Gill, G. A. and Fitzgerald, W. F.: Picomolar mercury measurements in seawater and other materials using stannous chloride reduction and two-stage gold amalgamation with gas phase detection, Mar. Chem., 20, 227-243, 1987.

Girard, E. and Blanchet, J.-P.: Microphysical parameterization of arctic diamond dust, ice fog, and this stratus for climate models, J. Atmos. Sci., 58, 10, 1181-1198, 2001.

Givelet, N., Roos-Barraclough, F., Goodsite, M. E., Cheburkin, A. K., and Shotyk, W.: Atmospheric mercury accumulation rates between 5900 and $800 \mathrm{cal}$ yr. BP in the High Arctic of Canada recorded by peat hummocks., Environ. Sci. Technol., 38, 49644972, 2004.

Gobeil, C., Macdonald, R. W., and Smith, J. N.: Mercury profiles in sediments of the Arctic Ocean basins, Environ. Sci. Technol., 33, 4194-4198, 1999.

Goodsite, M. E.: Fate of Mercury in the Arctic, PhD, University of Copenhagen, Copenhagen, 2003.

Goodsite, M. E., Plane, J. M. C., and Skov, H.: A theoretical study of the oxidation of $\mathrm{Hg}-0$ to $\mathrm{HgBr} 2$ in the troposphere, Environ. Sci. Technol., 38, 6, 1772-1776, 2004.

Grandjean, P., Weithe, P., White, R., Debes, F., Araki, S., Yokoyama, K., Muraata, K., Sørensen, N., Dahl, R., and Jørgensen, P. J.: Cognitive Deficit in 7-Year-Old Children with prenatal exposure to methylmercury, Neurotoxicol. Teratol., 19, 6, 417-428, 1997.

Grieg, G., Funning, H., and Strauz, O. P.: Reactions of metal atoms, J. Chem. Phys., 52, 3684-3690, 1970.

Hall, B. D.: The gas-phase oxidation of elemental mercury by ozone, Water Air Soil Poll., 80, 301-315, 1995.

Hall, G. E. M., Pelchat, J. C., and Vaive, J. E.: Sample collection, filtration and preservation protocols for the determination of "total dissolved" mercury in waters, Analyst, 127, 674-680, 2002.

Hammerschmidt, C. R., Chad, R., and Fitzgerald, W. F.: Photodecomposition of Methylmercury in an Arctic Alaskan Lake, Environ. Sci. Technol., 40, 4, 1212-1216, 2006a.

Hammerschmidt, C. R., Fitzgerald, W. F., Lamborg, C. H., Balcom, P. H., and Tseng, C. M.: Biogeochemical Cycling of Methylmercury in Lakes and Tundra Watersheds of Arctic Alaska, Environ. Sci. Technol., 40, 4, 1204-1211, 2006b.

Hammerschmidt, C. R., Lamborg, C. H., and Fitzgerald, W. F.: Aqueous phase methylation as a potential source of methylmer- cury in wet deposition, Atmos. Environ., 41, 1663-1668, 2007.

Heidam, N. Z., Christensen, J. H., Wahlin, P., and Skov, H.: Arctic atmospheric contaminants in NE Greenland: Levels, variations, origins, transport, transformations and trends 1990-2001, Sci. Total Environ., 331, 1-3, 5-28, 2004.

Hennebelle, R., Ferrari, C., Amato, P., Delort, A. M., Sancelme, M., Barbante, C., Cairns, W., and Boutron, C. F.: Interaction between Mercury and Arctic Bacteria in Snow. Implications on $\mathrm{Hg}$ cycle in polar areas, International conference on Polar and Alpine Microbiology, Innsbuck, 2006.

Hermanson, M. H.: Anthropogenic mercury deposition to Arctic lake sediments, Water Air Soil Poll., 101, 309-321, 1998.

Holmes, C. D., Jacob, D. J., and Yang, X.: Global lifetime of elemental mercury against oxidation by atomic bromine in the free troposphere, Geophys. Res. Lett., 33, 20, L20808, doi:10.1029/2006GL027176, 2006.

Hönninger, G. and Platt, U.: Observations of $\mathrm{BrO}$ and its vertical distribution during surface ozone depletion at Alert, Atmos. Environ., 36, 2481-2489, 2002.

Honrath, R. E., Peterson, M. C., Guo, S., Dibb, J. E., Shepson, P. B., and Campbell, B.: Evidence of NOx production within or upon ice particles in the Greenland snowpack, Geophys. Res. Lett., 26, 695-698, 1999.

Horne, D. G., Gosavi, R., and Strausz, O. P.: Reactions of Metal Atoms. I. The Combination of Mercury and Chlorine Atoms and the Dimerization of $\mathrm{HgCl}$, J. Chem. Phys., 48, 4758-4764, 1968.

Horvath, O. and Vogler, A.: Photoredox Chemistry of Chloromercurate(II) Complexes in Acetonitrile, Inorg. Chem., 32, 24, 5485-5489, 1993.

Hylander, L. D. and Goodsite, M. E.: Environmental costs of mercury pollution, Sci. Total Environ., 368, 1, 352-370, 2006.

Iversen, T. and Joranger, E.: Arctic air pollution and large scale atmospheric flows, Atmos. Environ., 19, 12, 2099-2108, 1985.

Jacobi, H.-W., Kaleschke, L., Richter, A., Rozanov, A., and Burrows, J. P.: Observation of a fast ozone loss in the marginal ice zone of the Arctic Ocean, J. Geophys. Res., 111, D15309, doi:10.1029/2005JD006715, 2006.

Jaffe, D., Prestbo, E., Swartzendruber, P., Weiss-Penzias, P., Kato, S., Takami, A., Hatakeyama, S., and Kajii, Y.: Export of atmospheric mercury from Asia, Atmos. Environ., 39, 3029-3038, 2005.

Jitaru, P., Infante, H. G., and Adams, F. C.: Multicapillary Gas Chromatography Coupled to Inductively coupled PlasmaTime-of-Flight Mass Spectrometry for Rapid Mercury Speciation Analysis, Anal. Chem., 489, 45-57, 2003.

Johansen, P., Pars, T., and Bjerregaard, P.: Lead, cadmium, mercury and selenium intake by Greenlanders from local marine food, Sci. Total Environ., 245, 187-194, 2000.

Johansen, P., Muir, D., Asmund, G., and Riget, F.: Human exposure to contaminants in the traditional Greenland diet, Sci. Total Environ., 331, 189-206, 2004.

Jones, G. H., Pomeroy, J. W., Walker, D. A., and Hoham, R. W. (Eds.): Snow Ecology: An Interdisciplinary Examination of Snow-Covered Ecosystems, in: Editors, Cambridge University Press, 45-118, 2001.

Kaleschke, L., Richter, A., Burrows, J., et al.: Frost flowers on sea ice as a source of sea salt and their influence on tropospheric halogen chemistry, Geophys. Res. Lett., 31, L16114, doi:10.1029/2004GL020655, 2004. 
Keeler, G., Glinsorn, G., and Pirrone, N.: Particulate mercury in the atmosphere: its significance, transport, transformation and sources, Water Air Soil Poll., 80, 159-168, 1995.

Khalizov, A. F., Viswanathan, B., Larregaray, P., and Ariya, P. A.: A theoretical study on the reactions of $\mathrm{Hg}$ with halogens: Atmospheric implications, J. Phys. Chem. A, 107, 33, 6360-6365, 2003.

Kim, K.-H., Ebinghaus, R., Schroeder, W. H., Blanchard, P., Kock, H. H., Steffen, A., Froude, F. A., Kim, M.-Y., Hong, S., and Kim, J.-H.: Atmospheric mercury concentrations from several observatory sites in the Northern Hemisphere, J. Atmos. Chem., 50, 1-24, 2005.

King, M. D. and Simpson, W. R.: Extinction of UV radiation in Arctic snow at Alert, Canada $\left(82^{\circ} \mathrm{N}\right)$, J. Geophys. Res., 106, 12 499-12 507, 2001.

Kirk, J. L.: Potential sources of monomethyl mercury in Arctic and Subarctic seawater, Arctic, 59, 108-111, 2006.

Kirk, J. L., St. Louis, V. L., and Sharp, M. J.: Rapid reduction and reemission of mercury deposited into snow packs during atmospheric mercury depletion events at Churchill, Manitoba, Canada, Environ. Sci. Technol., 40, 7590-7596, 2006.

Kock, H. H., Bieber, E., Ebinghaus, R., Spain, T. G., and Thees, B.: Comparison of long-term trends and seasonal variations of atmospheric mercury concentrations at the two European coastal monitoring stations Mace Head, Ireland and Zingst, Germany, Atmos. Environ., 39, 7549-7556, 2005.

Krembs, C.: Seasonal evolution of exopolymeric substances and their significance for the annual sea-ice productivity, International Conference on Alpine and Polar Microbiology, Innsbruck, Austria, 2006.

Lahoutifard, N., Sparling, M., and Lean, D.: Total and methyl mercury patterns in Arctic snow during springtime at Resolute, Nunavut, Canada, Atmos. Environ., 39, 7597-7606, 2005.

Lahoutifard, N., Poissant, L., and Scott, S. L.: Scavenging of gaseous mercury by acidic snow at Kuujjuarapik, Northern Québec, Sci. Total Environ., 355, 118-126, 2006.

Lalonde, J., Amyot, M., Kraepiel, A. M. L., and Morel, F. M. M.: Photooxidation of $\mathrm{Hg}(0)$ in artificial and natural waters, Environ. Sci. Technol., 35, 1367-1372, 2001.

Lalonde, J. D., Poulain, A. J., and Amyot, M.: The Role of Mercury Redox Reactions in Snow on Snow-to-Air Mercury Transfer, Environ. Sci. Technol., 36, 174-178, 2002.

Lalonde, J. D., Amyot, M., Doyon, M. R., and Auclair, J. C.: Photoinduced $\mathrm{Hg}$ (II) reduction in snow from the remote and temperate Experimental Lakes Area (Ontario, Canada), J. Geophys. Res.Atmos., 108, 6, 11-1-11-8, 2003.

Lalonde, J. D., Amyot, M., Orvoine, J., Morel, F. M. M., Auclair, J. C., and Ariya, P. A.: Photoinduced oxidation of $\mathrm{HgO}(\mathrm{aq})$ in the waters from the St. Lawrence Estuary, Environ. Sci. Technol., 38, 508-514, 2004.

Lamborg, C. H., Fitzgerald, W. F., Damman, A. W. H., Benoit, J. M., Balcom, P. H., and Engstrom, D. R.: Modern and historic atmospheric mercury fluxes in both hemispheres: global and regional mercury cycling implications, Global Biogeochem. Cy., 16, 1104, doi:10.1029/2001GB1847, 2002.

Landis, M., Stevens, R. K., Schaedlich, F., and Prestbo, E. M.: Development and characterization of an annular denuder methodology for the measurement of divalent inorganic reactive gaseous mercury in ambient air, Environ. Sci. Technol., 36, 3000-3009,
2002.

Laurier, F. J. G., Mason, R. P., Whalin, L., and Kato, S.: Reactive gaseous mercury formation in the North Pacific Ocean's marine boundary layer: A potential role of halogen chemistry, J. Geophys. Res.-Atmos., 108, ACH 3-1-ACH 3-12, 2003.

Leitch, D. R., Carrie, J., Lean, D., Macdonald, R. W., Stern, G. A., and Wang, F.: The delivery of mercury to the Beaufort Sea of the Arctic Ocean by the Mackenzie River, Sci. Total. Environ., 373, 1, 178-195, 2007.

Lin, C. J. and Pehkonen, S. O.: Oxidation of elemental mercury by aqueous chlorine $\left(\mathrm{HOCl} / \mathrm{OCl}^{-}\right)$: Implications for tropospheric mercury chemistry, J. Geophys. Res.-Atmos., 103(D21), $28093-$ $28102,1998$.

Lin, C. J. and Pehkonen, S. O.: The chemistry of atmospheric mercury: A review, Atmos. Environ., 33, 2067-2079, 1999.

Lindberg, S., Bullock, R., Ebinghaus, R., Engstrom, D. R., Feng, X., Fitzgerald, W. F., Pirrone, N., Prestbo, E., and Seigneur, C.: A synthesis of progress and encertainties in attributing the sources of mercury in deposition, Ambio, 36, 1, 19-32, 2007.

Lindberg, S. E., Brooks, S. B., Lin, C. J., Scott, K., Meyers, T., Chambers, L., Landis, M., and Stevens, R. K.: Formation of reactive gaseous mercury in the Arctic: evidence of oxidation of $\mathrm{Hg} 0$ to gas-phase $\mathrm{Hg}$-II compounds after arctic sunrise, Water Air Soil Poll., 1, 295-302, 2001.

Lindberg, S. E., Brooks, S., Lin, C.-J., Scott, K. J., Landis, M. S., Stevens, R. K., Goodsite, M., and Richter, A.: Dynamic oxidation of gaseous mercury in the Arctic troposphere at polar sunrise, Environ. Sci. Technol., 36, 1245-1256, 2002.

Lindqvist, O. and Rodhe, H.: Atmospheric mercury - a review, Tellus B, 37B, 136-159, 1985.

Loaec, M., Olierb, R., and Guezenneca, J.: Chelating properties of bacterial exopolysaccharides from deep-sea hydrothermal vents, Carbohyd. Polym., 35, 65-70, 1998.

Lockhart, L., Stern, G. A., Low, G., Hendzel, M., Boila, G., Roach, P., Evans, M. S., Billeck, B. N., DeLaronde, J., Friesen, S., Kidd, K., Atkins, S., Muir, D. C. G., Stoddart, M., Stephens, G., Stephenson, S., Harbicht, S., Snowshoe, N., Grey, B., and Thompson, S. D. N.: A history of total mercury in edible muscle of fish from lakes in northern Canada, Sci. Total Environ., 351-352, 427-463, 2005a.

Lockhart, W. L., Stern, G. A., Wagemann, R., Hunt, R. V., Metner, D. A., DeLaronde, J., Dunn, B., Stewart, R. E. A., Hyatt, C. K., Harwood, L., and Mount, K.: Concentrations and trends of mercury in tissues of beluga whales (Delphinapterus leucas) from the Canadian Arctic from 1981 to 2002, Sci. Total Environ., 351-352, 391-412, 2005b.

Loseto, L. L., Lean, D., and Siciliano, S. D.: Snowmelt sources of methylmercury to high arctic ecosystems, Environ. Sci. Technol., 38, 11, 3004-3010, 2004a.

Loseto, L. L., Siciliano, S. D., and Lean, D. R.: Methylmercury production in High Arctic wetlands, Environ. Toxicol. Chem., 23, 17-23, 2004b.

Lu, J. Y., Schroeder, W. H., Berg., T., Munthe, J., Schneeberger, D., and Schaedlich, F.: A Device for Sampling and Determination of Total Particulate Mercury in Ambient Air, Anal. Chem., 70, 11, 2403-2408, 1998.

Lu, J. Y. and Schroeder, W. H.: Comparison of conventional filtration and a denuder-based methodology for sampling of particulate-phase mercury in ambient air, Talanta, 49, 15-24, 
1999.

Lu, J. Y., Schroeder, W. H., Barrie, L. A., Steffen, A., Welch, H. E., Martin, K., Lockhart, L., Hunt, R. V., Boila, G., and Richter, A.: Magnification of atmospheric mercury deposition to polar regions in springtime: the link to tropospheric ozone depletion chemistry, Geophys. Res. Lett., 28, 3219-3222, 2001.

Lu, J. Y. and Schroeder, W. H.: Annual time-series of total filterable atmospheric mercury concentrations in the Arctic, Tellus, 56B, 213-222, 2004.

Lyu, E., Makarov, I. E., and Pikaev, A. K.: Pulse radiolysis of alkaline aqueous solutions of mercury(II) compounds, Khimiya Vysokikh Energii, 17, 1, 50-55, 1983.

Macdonald, R. W. and Bewers, J. M.: Contaminants in the arctic marine environment: priorities for protection, ICES J. Mar. Sci., 53, 537-563, 1996.

Macdonald, R. W., Harner, T., and Fyfe, J.: Recent climate change in the Arctic and its impact on contaminant pathways and interpretation of temporal trend data, Sci. Total. Environ., 342, 5-86, 2005.

Mann, J. L., Long, S. E., Shuman, C. A., and Kelly, W. R.: Determination of Mercury content in a shallowfirn core from Greenland by isotope dilution inductively coupled plasma mass spectrometry, Water Air Soil Poll., 163, 19-32, 2005.

Martinez-Cortizas, A., Pontevedra-Pombal, X., Garcia-Rodeja, E., Novoa-Munoz, J. C., and Shotyk, W.: Mercury in a spanish peat bog: Archive of climate change and atmospheric metal deposition, Science, 284, 939-929, 1999.

Mason, R. P., Fitzgerald, W. F., and Morel, F. M. M.: The biogeochemical cycling of elemental mercury: anthropogenic influences, Geochim. Cosmochim. Ac., 58, 3191-3198, 1994.

Mason, R. P., Rolfhus, K. R., and Fitzgerald, W. F.: Mercury in the North Atlantic, Mar. Chem., 61, 1-2, 37-53, 1998.

Mason, R. P. and Sheu, G.-R.: Role of the ocean in the global mercury cycle, Global Biogeochem. Cy., 16, 1093, doi:10.1029/2001GB001440., 2002.

Mayewski, P. A., Meeker, L. D., Twickler, M. S., Whitlow, S., Yang, Q., Lyons, W. B., and Prentice, M.: Major features and forcing of high-latitude northern hemisphere atmospheric circulation using a 110,000-year-long glaciochemical series, J. Geophys. Res., 102, 26345-26366, 1997.

Meyers, T. P., Hall, M. E., Lindberg, S. E., and Kim, K.-H.: Use of the modified Bowen-ratio technique to measure fluxes of trace gases, Atmos. Environ., 30, 19, 3321-3329, 1996.

Muench, R. D., Smith, D. C. I., and Paulson, C. A.: Convection beneath freezing leads: New observations compared with numerical model results, J. Geophys. Res., 100(C3), 4681-4692, 1995.

Muir, D. C. G., Wageman, R., Hargrave, B. T., Thomas, D. J., Peakall, D. B., and Norstrom, R. J.: Arctic marine ecosystem contamination, Sci. Total Environ., 122, 75-134, 1992.

Müller, R. W., Bovensmann, H., Kaiser, J. W., Richter, A., Rozanov, A., Wittrock, F., and Burrows, J. P.: Consistent Interpretation of Ground based and GOME BrO Slant Column Data, Adv. Space Res., 29, 1655-1660, 2002.

Munthe, J.: The Aqueous Oxidation of Elemental Mercury by Ozone, Atmos. Environ., 26, 8, 1461-1468, 1992.

Munthe, J., Wangberg, I., Pirrone, N., Iverfeldt, A., Ferrara, R., Ebinghaus, R., Feng, X., Gardfeldt, K., Keeler, G., Lanzillotta, E., Liundberg, S. E., Lu, J., Mamane, Y., Prestbo, E., Schmolke, S., Schroeder, W. H., Sommar, J., Sprovieri, F., Stevens, R. K.,
Stratton, W., Tuncel, G., and Urba, A.: Intercomparison of methods for sampling and analysis of atmospheric mercury species, Atmos. Environ., 35, 3007-3017, 2001.

Niki, H., Maker, P. S., Savage., C. M., and Breitenbach, L. P.: A long path Fourier Transform IR study of kinetics and mechnaism of the reaction of $\mathrm{Cl}+$ dimethyl merury, J. Phys. Chem.-US, 87, 3722-3724, 1983a.

Niki, H., Maker, P. S., Savage, C. M., and Breitenbach, L. P.: A long path Fourier Transform IR study of kinetics and mechnaism of the reaction of HO-initiated oxcidation of dimethyl merury, J. Phys. Chem.-US, 87, 4978-4981, 1983 b.

O'Driscoll, N. J., Siciliano, S. D., Lean, D. R. S., and Amyot, M.: Gross photoreduction kinetics of mercury in temperate freshwater lakes and rivers: application to a general model of DGM dynamics, Environ. Sci. Technol., 40, 837-843, 2006.

Oehme, M.: Further evidence for long-range air transport of polychlorinated aromates and pesticides: North America and Eurasia to the Arctic, Ambio, 20, 7, 293-297, 1991.

Olofsson, M., Sommar, J., Ljungström, E. and Andersson, M.: Application of relaxed eddy accumulation to quantify $\mathrm{Hg}^{0}$ fluxes over modified soil surfaces, Water Air Soil Poll, 167, 331-354., 2005.

Oncley, S. P., Delany, A. C., Horst, T. W., and Trans, P. P.: Verification of flux measurement using relaxed eddy accumulation, Atmos. Environ. A-Gen, 27, 15, 2417-2426, 1993.

Pacyna, E. G., Pacyna, J. M., Steenhuisen, F., and Wilson, S.: Global anthropogenic mercury emission inventory for 2000, Atmos. Environ., 40, 4048-4063, 2006.

Pal, B. and Ariya, P. A.: Kinetics and mechanism of $\mathrm{O}_{3}$-initiated reaction of $\mathrm{Hg}^{0}$ : atmospheric implication, J. Phys. Chem.-Chem. Phys., 6, 572-579, 2004.

Parker, J. L. and Bloom, N. S.: Preservation and storage techniques for low-level aqueous mercury speciation, Sci. Total Environ., 337, 1-3, 253-263, 2005.

Patterson, C. C. and Settle, D. M.: Accuracy in Trace Analysis, U.S. Government Printing Office, Washington, DC, 1976.

Petersen, G., Iverfeldt, A., and Munthe, J.: Atmospheric mercury species over central and northern Europe. Model calculations and comparison with observations from the Nordic air and precipitation network for 1987 and 1988, Atmos. Environ., 29, 47-67, 1995.

Pinto, J. O. and Curry, J. A.: Atmospheric convective plumes emanating from leads 2. Microphysical and radiative processes, J. Geophys. Res., 100(C3), 4633-4642, 1995.

Pinto, J. O., Curry, J. A., and McInnes, K. L.: Atmospheric convective plumes emanating from leads 1 . Thermodynamic structure, J. Geophys. Res., 100(C3), 4621-4631, 1995.

Planchon, F. A. M., Gabrielli, P., Gauchard, P. A., Dommergue, A., Barbante, C., Cairns, W. R. L., Cozzi, G., Nagorski, S. A., Ferrari, C. P., Capodaglio, G., Cescon, P., Varga, A., and Wolff, E. W.: Direct determination of mercury at the sub-picogram per gram level in polar snow and ice by ICP-SFMS, J. Anal. Atom. Spectrom., 19, 7, 823-830, 2004.

Poissant, L. and Pilote, M.: Time series analysis of atmospheric mercury in Kuujjuarapik/Whapmagoostui (Quebec), J. Phys. IV, 107, 2, 1079-1082, 2003.

Pongratz, R. and Heumann, K. G.: Production of methylated mercury and lead by polar macroalgae - a significant natural source for atmospheric heavy metals in clean room compart- 
ments, Chemosphere, 36, 1935-1946, 1998.

Poulain, A. J., Lalonde, J. D., Amyot, J. D., Shead, J. A., Raofie, F., and Ariya, P. A.: Redox transformations of mercury in an Arctic snowpack at springtime, Atmos. Environ., 38, 6763-6774, 2004.

Poulain, A. J., Garcia, E., Amyot, J. D., Campbell, P. G. C., Raofie, F., and Ariya, P. A.: Biological and chemical redox transformations of mercury in fresh and salt waters of the high Arctic during spring and summer, Environ. Sci. Technol., 41, 1883-1888, 2007a.

Poulain, A. J., Ni Chadhain, S. M., Ariya, P. A., Amyot, M., Garcia, E., Campbell, P. G. C., Zylstra, G., and Barkay, T.: A potential for mercury reduction by microbes in the high Arctic, Appl. Environ. Microb., 73, 7, 2230-2238, 2007b.

Poulain, A. J., Garcia, E., Amyot, M., Campbell, P. G. C., and Ariya, P.: Mercury distribution, partitioning and speciation in coastla vs. inland high arctic snow, Geochim. Cosmochim. Ac., 71, 14, 3419-3431, 2007c.

Raatz, W. E.: Tropospheric circulation patterns during the Arctic gas and aerosol sampling program (AGASP), March/April 1983, Geophys. Res. Lett., 11, 449-452, 1984.

Raatz, W. E. and Shaw, G. E.: Long-range tropospheric transport of pollution aerosols into the Alaskan arctic, J. Clim. Appl. Meteorol., 7, 23, 1052-1064, 1984.

Raatz, W. E.: The climatology and meteorology of Arctic air pollution, in: Pollution of the Arctic Atmosphere, Elsevier, New York, 13-42, 1992.

Rankin, A. M., Wolff, E. W., and Martin, S.: Frost flowers: Implications for tropospheric chemistry and ice core interpretation, J. Geophys. Res., 107(D23), 4683, doi:10.1029/2002JD002492, 2002.

Raofie, F. and Ariya, P. A.: Reactions of BrO with mercury: kinetic studies, J. Phys. IV, 107, 1119-1121, 2003.

Raofie, F. and Ariya, P. A.: First evidence for stable $\mathrm{Hg}^{+1}$ in the aerosols, Environ. Sci. Technol., 38, 4319-4326, 2004.

Richter, A., Wittrock, F., Eisinger, M., and Burrows, J. P. (Eds.): GOME observations of tropospheric BrO in Northern Hemispheric spring and summer 1997, Geophys. Res. Lett., 25, 26832686, 1998.

Riget, F., Dietz, R., Born, E. W., Sonne, C., and Hobson, K. A.: Temporal trends of mercury in marine biota of west and northwest Greenland, Mar. Pollut. Bull., 54, 1, 72-80, 2007.

Ryaboshapko, A., Bullock, R., Christensen, J., Cohen , M., Dastoor, A., Ilyin, I., Petersen, G., Syrakov, D., Artz, R., Davignon, D., Draxler, R., and Munthe, J.: Intercomparison study of atmospheric mercury models: 1 . Comparison of models with shortterm measurements, Sci. Total. Environ., 376, 228-240, 2007.

Saint-Amour, D., Roy, M.-S., Bastien, C., Ayotte, P., Dewailly, E., Després, Gingras, S., and Muckle, G.: Alterations of visual evoked potentials in preschool Inuit children exposed to methylmercury and polychlorinated biphenyls from a marine diet, Neuro Toxicology, 27, 567-578, 2006.

Schimel, J.: News and Views; Global change: Rice, microbes and methane, Nature, 403, 375-377, 2000.

Schroeder, W. H., Yarwood, G., and Niki, H.: Involving Mercury Species in the Atmosphere - Results from a Literature Survey, Water Air Soil Poll., 56, 653-666, 1991.

Schroeder, W. H. and Munthe, J.: Atmospheric mercury - an overview, Atmos. Environ., 32, 5, 809-822, 1995.

Schroeder, W. H., Anlauf, K. G., Barrie, L. A., Lu, J. Y., Steffen, A.,
Schneeberger, D. R., and Berg, T.: Arctic springtime depletion of mercury, Nature, 394, 331-332, 1998.

Schroeder, W. H., Steffen, A., Scott, K., Bender, T., Prestbo, E., Ebinghaus, R., Lu, J., and Lindberg, S.: Summary report: first international Arctic atmospheric mercury research workshop, Atmos. Environ., 37, 18, 2551-2555, 2003.

Scott, K.: Bioavailable Mercury in Arctic Snow Determined by a Light-Emitting mer-lux Bioreporter, Arctic, 54, 1, 92-101, 2001.

Semkin, R. G., Mierle, G., and Neureuther, R. J.: Hydrochemistry and mercury cycling in a High Arctic watershed, Sci. Total Environ., 342, 1-3, 199-221, 2005.

Serreze, M. C., Maslanik, J. A., Scambos, T. A., Fetterer, F., Stroeve, J., Knowles, K., Fowler, C., Drobot, S., Barry, R. G., and Haran, T. M.: A record minimum arctic sea ice extent and area in 2002, Geophys. Res. Lett., 30(3), p. 10-1, 2003.

Shepler, B. C., Balabanov, N. B., and Peterson, K.: Ab initio thermochemistry involving heavy atoms: An investigation of the reactions Hg + IX (X = I, Br, Cl, O), J. Phys. Chem.-US, 109, 45, 10363-10372, 2005.

Sheppard, D. S., Patterson, J. E., and McAdam, M. K.: Mercury Content of Antarctic Ice and Snow - Further Results, Atmos. Environ. A-Gen, 25, 1657-1660, 1991.

Shotyk, W., Goodsite, M. E., Roos-Barraclough, F., Heinemeier, J., Frei, R., Asmund, G., Lohse, C., and Stroyer, T. H.: Anthropogenic contributions to atmospheric $\mathrm{Hg}, \mathrm{Pb}$, and As deposition recorded by peat cores from Greenland and Denmark dated using the 14C ams "bomb pulse curve", Geochim. Cosmochim. Ac., 67, 21, 3991-4011, 2003.

Shotyk, W., Goodsite, M. E., Roos-Barraclough, F., Givelet, N., Le Roux, G., Weiss, D., Cheburkin, A. K., Knudsen, K., Heinemeier, J., van der Knaap, W. O., Norton, S. A., and Lohse, C.: Accumulation rates and predominant atmospheric sources of natural and anthropogenic $\mathrm{Hg}$ and $\mathrm{Pb}$ on the Faroe Islands, Geochim. Cosmochim. Ac., 69, 1-17, 2005.

Siciliano, S. D., O’driscoll, N. J., Tordon, R., Hill, J., Beauchamp, S., and Lean, D. R. S.: Abiotic production of methylmercury by solar radiation, Environ. Sci. Technol., 39, 1071-1077, 2005.

Simpson, W., Von Glasow, R., Riedel, K., Anderson, P., Ariya, P. A., Bottenheim, J., Burrows, J. P., Carpenter, L., Freisse, U., Goodsite, M., Heard, D., Hutterli, M., Jacobi, H.-W., Kaleschke, L., Neff, B., Plane, J., Platt, U., Richter, A., Roscoe, H., Sander, R., Shepson, P. B., Sodeau, J., Steffen, A., Wagner, T., and Wolff, E.: Halogens and their role in polar boundary-layer ozone depletion, Atmos. Chem. Phys., 7, 16, 4375-4418, 2007.

Simpson, W. R., Alvarez-Aviles, L., Douglas, T. A., and Sturm, M.: Halogens in the coastal snow pack near Barrow, Alaska: Evidence for active bromine air-snow chemistry during springtime, Geophys. Res. Lett., 32, L04811, doi:10.1029/2004GL021748, 2005.

Skov, H., Christensen, J. H., Heidam, N. Z., Jensen, B., Wahlin, P., and Geernaert, G.: Fate of elemental mercury in the Artcic during atmospheric depletion episodes and the load of atmospheric mercury to the Arctic, Environ. Sci. Technol., 38, 2373-2382, 2004.

Skov, H., Goodsite, M. E., Lindberg, S. E., Meyers, T. P., Landis, M., Larsen, M. R. B., and McConville, G.: The fluxes of Reactive Gaseous mercury measured with a newly developed method using relaxed eddy accumulation, Atmos. Environ., 40, 5452 $5463,2006$. 
Slemr, F., Brunke, E., Ebinghaus, R., Temme, C., Munthe, J., Wängberg, I., Schroeder, W. H., Steffen, A., and Berg, T.: Worldwide trend of atmospheric mercury since 1977, Geophys. Res. Lett., 30, 10, 23-1-23-4, 2003.

Smithwick, M., Mabury, S. A., Solomon, K. R., Sonne, C., Martin, J. W., Born, E. W., Dietz, R., Derocher, A. E., Letcher, R. J., Evans, T. J., Gabrielsen, G. W., Nagy, J., Stirling, I., Taylor, M. K., and Muir, D. C. G.: Circumpolar Study of Perfluoroalkyl Contaminants in Polar Bears (Ursus maritimus), Environ. Sci. Technol., 39, 5517-5523, 2005.

Snyder-Conn, E., Garbarino, J. R., Hoffman, G. L., and Oelkers, A.: Soluble Trace Elements and Total Mercury in Arctic Alaskan Snow, Arctic, 50, 201-215, 1997.

Sommar, J., Hallquist, M. and Ljungstrom, E.: Rate of reaction between the nitrate radical and dimethyl mercury in the gas phase, Chem. Phys. Lett., 257, 434-438, 1996.

Sommar, J., Hallquist, M., Ljungström, E., and Lindqvist, O.: On the Gas Phase Reactions Between Volatile Biogenic Mercury Species and the Nitrate Radical, J. Atmos. Chem., 27, 233-247, 1997.

Sommar, J., Gardfeldt, K., Stromberg, D., and Feng, X.: A kinetic study of the gas-phase reaction between the hydroxyl radical and atomic mercury, Atmos. Environ., 35, 3049-3054, 2001.

Sommar, J., Wangberg, L., Berg, T., Gardfeldt, K., Munthe, J., Richter, A., Urba, A., Wittrock, F., and Schroeder, W. H.: Circumpolar transport and air-surface exchange of atmospheric mercury at Ny-Alesund $\left(79^{\circ} \mathrm{N}\right)$, Svalbard, spring 2002, Atmos. Chem. Phys., 7, 1, 151-166, 2007.

Sprovieri, F., Pirrone, N., Hedgecock, I. M., Landis, M. S., and Stevens, R. K.: Intensive atmospheric mercury measurements at Terra Nova Bay in Antarctica during November and December 2000, J. Geophys. Res., 107, 4722, doi:10.1029/2002JD002057, 2002.

Sprovieri, F., Pirrone, N., Landis, M., and Stevens, R. K.: Oxidation of gaseous elemental mercury to gaseous divalent mercury during 2003 polar sunrise at Ny-Alesund, Environ. Sci. Technol., 39, 9156-9165, 2005a.

Sprovieri, F., Pirrone, N., Landis, M., and Stevens, R. K.: Atmospheric mercury behaviour at different altitudes at Ny Alesund during Spring 2003, Environ. Sci. Technol., 39, 7646-7656, 2005 b.

St. Louis, V. L., Sharp, M. J., Steffen, A., May, A., Barker, J., Kirk, J. L., Kelly, D. J. A., Arnott, S. E., Keatley, B., and Smol, J. P.: Some Sources and Sinks of Monomethyl and Inorganic Mercury on Ellesmere Island in the Canadian High Arctic, Environ. Sci. Technol., 39, 8, 2686-2701, 2005.

Steffen, A., Schroeder, W. H., Bottenheim, J., Narayan, J., and Fuentes, J. D.: Atmospheric mercury concentrations: measurements and profiles near snow and ice surfaces in the Canadian Arctic during Alert 2000, Atmos. Environ., 36, 2653-2661, 2002.

Steffen, A., Schroeder, W. H., Edwards, G., and Banic, C.: Mercury throughout polar sunrise 2002, J. Phys. IV, 107, 1267-1270, 2003a.

Steffen, A., Schroeder, W. H., Poissant, L., and MacDonald, R.: Mercury in the arctic atmosphere, Indian and Northern Affairs Canada, Ottawa, 124-142, 2003b.

Steffen, A., Schroeder, W. H., Macdonald, R., Poissant, L., and Konoplev, A.: Mercury in the arctic atmosphere: an analysis of eight years of measurements of GEM at Alert (Canada) and a comparison with observations at Amderma (Russia) and Kuujjuarapik (Canada), Sci. Total Environ., 342, 185-198, 2005.

Stohl, A.: Characteristics of atmospheric transport into the Arctic troposphere, J. Geophys. Res., 111, D11306, doi:10.1029/2005JD006888, 2006.

Stratton, W. J. and Lindberg, S. E.: Use of a refluxing mist chamber for measurement of gas-phase mercury (II) species in the atmosphere, Water Air Soil Poll., 80, 1269-1278, 1995.

Stroeve, J. C., Serreze, M. C., Fetterer, F., Arbetter, T., Meier, W., Maslanik, J., and Knowles, K.: Tracking the Arctic's shrinking ice cover: Another extreme September minimum in 2004, Geophys. Res. Lett., 32, L04501, doi:10.1029/2004GL021810, 2005.

Sturm, M. and Liston, G. E.: The snow cover on lakes of the Arctic Coastal Plain of Alaska, USA, J. Glaciol., 49, 166, 370-380, 2003.

Sumner, A. L. and Shepson, P. B.: Snowpack production of formaldehyde and its effect on the Arctic troposphere, Nature, 398, 230-233, 1999.

Sumner, A. L., Pirrone, N., and Mahaffey, K. R. (Eds.): Where We Stand on Mercury Pollution and its Health Effects on Regional and Global Scales, in: Dynamics of mercury pollution on regional and global scales. Atmospheric processes and human exposures around the world, Springer, US, 1-21, 2005.

Tackett, P. J., Cavender, A., Shepson, P. B., Bottenheim, J. W., Morin, S., Deary, J., and Steffen, A.: A Study of the vertical scale of halogen chemistry in the Arctic troposphere during polar sunrise at Barrow, AK., J. Geophys. Res., 112, D07306, doi:10.1029/2006JD007785, 2007.

Temme, C., Einax, J. W., Ebinghaus, R., and Schroeder, W. H.: Measurements of Atmospheric Mercury Species at a Coastal Site in the Antarctic and over the South Atlantic Ocean during Polar Summer, Environ. Sci. Technol., 37, 22-31, 2003.

Temme, C., Ebinghaus, R., Einax, J. W., Steffen, A., and Schroeder, W. H.: Application of time series analysis on long-time data sets of atmospheric mercury concentrations at two different sites, Anal. Bioanal. Chem., 380, 493-501, 2004.

Temme, C., Blanchard, P., Steffen, A., Beauchamp, S. T., Poissant, L., Tordon, R. J., and Weins, B.: Trend, seasonal and multivariate analysis study of total gaseous mercury data from the Canadian Atmospheric Mercury Measurement Network (CAMNet), Atmos. Environ., 41, 5423-5441, 2007.

Thompson, D. R., Beyer, W. N., Heinz, G. H., and RedmonNorwood, A. W. (Eds.): Mercury in birds and terrestrial mammals, in: Environmental contaminants in wildlife: Interpreting tissue concentrations, CRC Press, 341-356, 1996.

Tokos, J. J. S., Hall, B., Calhoun, J. A., and Prestbo, E. M.: Homogeneous gas-phase reaction of $\mathrm{Hg}^{\circ}$ with $\mathrm{H}_{2} \mathrm{O}_{2}, \mathrm{O}_{3}, \mathrm{CH}_{3} \mathrm{I}$, AND $\left(\mathrm{CH}_{3}\right)_{2} \mathrm{~S}$ : Implications for atmospheric $\mathrm{Hg}$ cycling, Atmos. Environ., 32, 823-827, 1998.

Travnikov, O. and Ryaboshapko, A.: Modelling of mercury hemispheric transport and depositions, Meteorological Synthesizing Centre-East, Moscow, Russia, 2002.

Travnikov, O.: Contribution of the intercontinental atmospheric transport to mercury pollution in the Northern Hemisphere, Atmos. Environ., 39, 7541-7548, 2005.

Tseng, C. M., Lamborg, C., Fitzgerald, W. F., and Engstrom, D. R.: Cycling of dissolved elemental mercury in Arctic Alaskan lakes, Geochim. Cosmochim. Ac., 68, 6, 1173-1184, 2004. 
UNEP: Global Mercury Assessment, UNEP Chemicals, Geneva, Switzerland, 2002.

van Aardenne, J. A., Carmichael, G. R., Levy, H., Streets, D., and Hordijk, L.: Anthropogenic NOx emissions in Asia in the period 1990-2020, Atmos. Environ., 33, 4, 633-646, 1999.

Van Loon, L., Mader, E., and Scott, S. L.: Reduction of the aqueous mercuric ion by sulfite: UV spectrum of $\mathrm{HgSO} 3$ and its intramolecular redox reaction, J. Phys. Chem. A, 104, 8, 16211626, 2000.

Van Loon, L. L., Mader, E. A., and Scott, S. L.: Sulfite stabilization and reduction of the aqueous mercuric ion: Kinetic determination of sequential formation constants, J. Phys. Chem. A, 105, 13, 3190-3195, 2001.

van Roozendael, M., Wagner, T., Richter, A., Pundt, I., Arlander, D. W., Burrows, J. P., Chipperfield, M., Fayt, C., Johnston, P. V., Lambert, J.-C., Kreher, K., Pfeilsticker, K., Platt, U., Pommereau, J.-P., Sinnhuber, B.-M., Toernkvist, K. K., and Wittrock, F.: Intercomparison of BrO Measurements from ERS-2 GOME, ground-based and Balloon Platforms, Adv. Space Res., 29, 1661-1666, 2002.

Vandal, G. M., Fitzgerald, W. F., Boutron, C. F., and Candelone, J. P.: Variations in mercury deposition to Antarctica over the past 34000 years, Nature, 362, 621-623, 1993.

Wagemann, R., Trebacz, E., Hunt, R. V., and Boila, G.: Percent methylmercury and organic mercury in tissues of marine mammals and fish using different experimental and calculation methods, Environ. Toxicol. Chem., 16, 9, 1859-1866, 1997.

Wagemann, R., Trebacz, E., Boila, G., and Lockhart, W. L.: Methylmercury and total mercury in tissues of arctic marine mammals, Sci. Total Environ., 218, 19-31, 1998.

Wagner, T. and Platt, U.: Observation of tropospheric BrO from GOME satellite, Nature, 395, 486-490, 1998.

Wallace, J. M. and Gutzler, D. S.: Teleconnections in the Geopotential Height Field during the Northern Hemisphere Winter, Mon. Weather Rev., 109, 784-812, 1981.
Wallschlager, D., Turner, R. R., London, J., Ebinghaus, R., Kock, H. H., Sommar, J., and Xiao, Z. J.: Factors affecting the measurement of mercury emissions from soils with flux chambers, Geophys. Res. Lett., 104, 21 859-21 871, 1999.

Wang, Z. and Pehkonen, S. O.: Oxidation of elemental mercury by aqueous bromine: atmospheric implications, Atmos. Environ., 38, 22, 3675-3688, 2004.

Wangberg, I., Sommar, J., Berg, T., Gardfeldt, K., and Munthe, J.: Interpretation of mercury depletion events observed at $\mathrm{Ny}$ Alesund, Svalbard during spring 2002, J. Phys. IV, 107, 2, $1353-$ 1356, 2003.

Wania, F. and Mackay, D.: Tracking the distribution of persistent organic pollutants, Environ. Sci. Technol., 30, 390-396A, 1996.

Watras, C. J., Morrison, K. A., Host, J. S., and Bloom, N. S.: Concentration of mercury species in relationship to other site-specific factors in the surface waters of northern Wisconsin lakes, Limnol. Oceanogr., 40, 556-565, 1995.

Weller, R. and Schrems, O.: Photooxidants in the marine arctic troposphere in summer, J. Geophys. Res., 101(D4), 9139-9147, 1996.

Wesely, M. L.: Parameterization of surface resistances to gaseous dry deposition in regional-scale numerical models, Atmos. Environ., 23, 1293-1304, 1989.

Williston, S. H.: Mercury in the atmosphere, J. Geophys. Res., 73, 7051-7055, 1968.

Xiao, Z., Sommar, J., Wei, S., and Lindqvist, O.: Sampling and determination of divalent mercury in air using $\mathrm{KCl}$ coated denuders, Fresen J. Anal. Chem., 358, 386-391, 1997.

Zhang, H. and Lindberg, S. E.: Sunlight and Fe(III)-induced photochemical production of dissolved gaseous mercury in freshwater, Environ. Sci. Technol., 35, 928-935, 2001. 